Artur Zappalenti

\title{
INFLUÊNCIA DOS PARÂMETROS DE USINAGEM NO BROCHAMENTO DE UM BLOCO EM FERRO FUNDIDO
}

Dissertação apresentada ao Departamento de Engenharia Mecânica como parte dos requisitos para defesa da dissertação de mestrado

ORIENTADOR: Prof. Dr. Reginaldo Teixeira Coelho

São Carlos

2007 


\section{Agradecimentos}

Ao professor Reginaldo Teixeira Coelho pela orientação.

Aos professores Eduardo Vila, Oswaldo Agostinho e João Fernando dos departamentos de Engenharia Mecânica e de Engenharia de Produção pelo conhecimento transmitido.

A Ana Paula do Departamento de Pós-Graduação da Engenharia Mecânica e ao Cristiano e a D. Irene da Engenharia de Produção.

Aos meus amigos e incentivadores no decorrer desta etapa, Marcos Gati e Léia, Matheus e Adriana, Oscar, Vander, Capla, Evandro, Denílson, André, Pancher, Cledson, Deveikis, Barrico e Desirée.

Ao professor Lincoln Cardoso Brandão pela orientação e direcionamento inicial do trabalho.

A todos que contribuíram para a realização deste trabalho. 


\section{RESUMO}

ZAPPALENTI, A. (2007). Influência dos parâmetros de usinagem no brochamento de um bloco em ferro fundido. Dissertação (Mestrado) - Escola de Engenharia de São Carlos, Universidade de São Paulo. São Carlos, 2007.

O objetivo do presente trabalho é analisar a influência de alguns parâmetros de usinagem na qualidade geométrica e superficial da peça. O brochamento é uma operação de usinagem antiga, a qual se desenvolveu com a indústria automobilística, mas que atualmente pode ser encontrada em diversos segmentos industriais. O processo consiste em uma remoção progressiva do material pela ação de uma ferramenta de corte multi-arestas. Este processo é capaz de, em um único ciclo, realizar as operações de desbaste e acabamento da peça em virtude da combinação de uma geometria adequada da ferramenta, tornando esta uma importante característica deste processo. Para o trabalho em questão, foi analisado um processo brochamento de acabamento na usinagem de blocos fabricados em ferro fundido. Este material foi escolhido por estar bastante presente na indústria de transformação devido à boa usinabilidade. Os resultados foram obtidos em medições com aparelhos eletrônicos e através de análise estatística foi avaliado o grau de interferência dos fatores para as características estudadas. Os resultados mostraram que os fatores e suas combinações interferem de forma diferente para cada característica analisada. Na maioria das situações analisadas, os fatores que individualmente apresentam significância para determinada característica, quando combinados entre si também podem interferir no resultado, este fato fica evidenciado com a análise dos resultados obtidos com as ferramentas diamantadas.

[Palavras-chave: brochamento; parâmetros de usinagem; geometria; ferro fundido] 


\begin{abstract}
ZAPPALENTI, A. (2007). Influence of the machining parameters on the broaching of a casting iron block. Dissertação (Mestrado) - Escola de Engenharia de São Carlos, Universidade de São Paulo. São Carlos, 2007
\end{abstract}

The objective of the present paperwork is to analyze the influence of some machining parameters on the geometrical and surface qualities of the work piece. The broaching is an old machining operation, which was developed with the automobile industry, but which nowadays can be found in diverse industrial segments. The process consists on a progressive removal of the material by a multi-edge cutting tool. This process is able of, in a single cycle, do the operations of the part's looping and finishing because of a peculiar geometrical configuration of the tool, what is an important characteristic of this process. For the paperwork on proposal, it was analyzed a process broaching of finishing in the machining of blocks made of cast iron. This material was chosen for being very present in the transformation industry due to its machinability. The results were obtained on measurements with electronic devices, and through statistical analysis it was analyzed the degree of interference of the factors to the studied characteristics. The results showed which the factors and its combinations interfere on a different way for each analyzed characteristic. In the most of the analyzed situations, the factors which individually present significance for determined characteristic, when combined among themselves, can interfere in the result too. This fact becomes evident with the analysis of the obtained results with the diamonded tools.

[Key-words: broaching; machining parameters; geometry; cast iron] 


\section{LISTA DE FIGURAS}

Figura 2.1 - Geometria de brocha de corte............................................................. 9

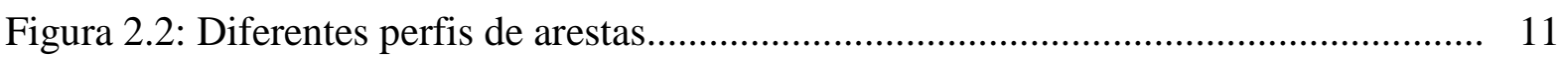

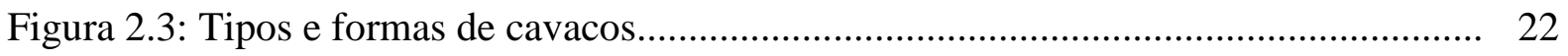

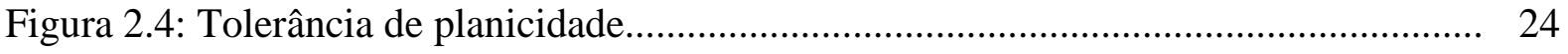

Figura 2.5: Representação da rugosidade superficial........................................................ 25

Figura 2.6: Faixas de valores de rugosidade em função de diferentes processos de

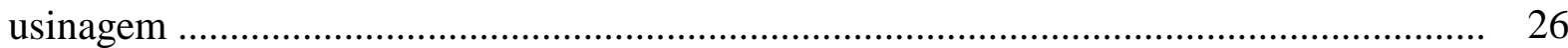

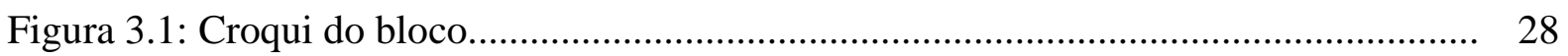

Figura 3.2: Aspecto geral do bloco a ser estudado....................................................... 29

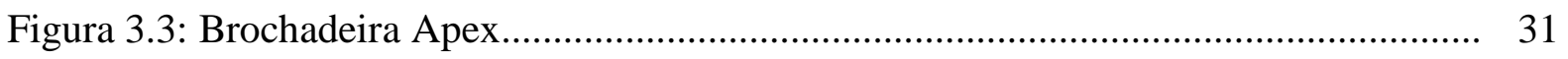

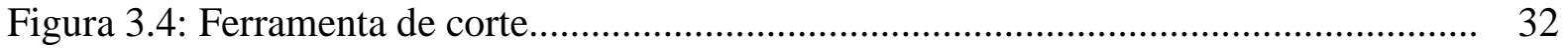

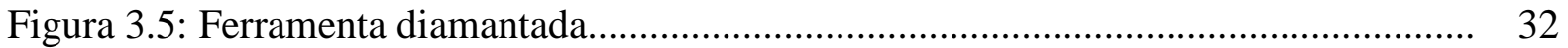

Figura 3.6: Sistema de medição das características geométricas....................................... 35

Figura 3.7: Aparelho Tropel Flat Master 200.................................................................... 35

Figura 3.8: Representação da planicidade de uma peça medida no Tropel......................... 36

Figura 3.9: Rugosímetro Taylor Robson.................................................................... 37

Figura 4.1: Gráficos de resíduo para Rugosidade Ra..................................................... 40

Figura 4.2: Interferência das Variáveis no Processo para Rugosidade Ra......................... 41

Figura 4.3: Análise do Intervalo de $95 \%$ de confiança para os quatro fatores em ralação à

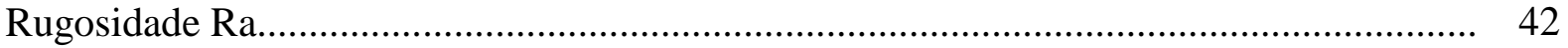

Figura 4.4: Gráficos de interações entre os fatores para Rugosidade Ra............................ 44

Figura 4.5: Gráficos de Resíduo para Perpendicularismo................................................. 46

Figura 4.6: Interferência das Variáveis no Processo para Perpendicularismo..................... 47

Figura 4.7: Analise do Intervalo de 95\% de confiança para os quatro fatores em relação

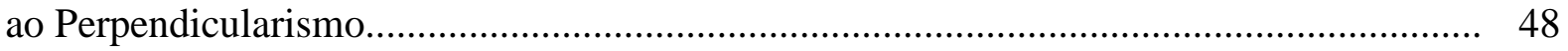

Figura 4.8: Gráficos de interações entre os fatores para Perpendicularismo....................... 50

Figura 4.9: Gráficos de Resíduo para Conicidade Horizontal........................................... 52

Figura 4.10: Interferência das Variáveis no Processo para Conicidade Horizontal.............. 53

Figura 4.11: Analise do Intervalo de 95\% de confiança para os quatro fatores.................. 54

Figura 4.12: Gráficos das interações entre os fatores Para Conicidade Horizontal............. 56

Figura 4.13: Gráficos de Resíduo para Conicidade Vertical............................................ 58

Figura 4.14: Interferência das Variáveis no Processo para Conicidade Vertical.................. 59 
Figura 4.15: Análise do Intervalo de 95\% de confiança para os quatro fatores................... 60

Figura 4.16: Gráfico de interação dos fatores para Conicidade Vertical............................ 62

Figura 4.17: Gráficos de Resíduo para Planicidade S................................................... 63

Figura 4.18: Interferência das Variáveis no Processo para Planicidade S.......................... 64

Figura 4.19: Analise do Intervalo de $95 \%$ de confiança para os quatro fatores para

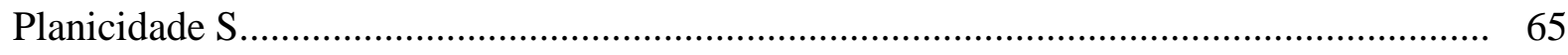

Figura 4.20: Gráfico de interação dos fatores para Planicidade S.................................... 67

Figura 4.21: Gráficos de resíduos para Planicidade A ….................................................... 69

Figura 4.22: Interferência das Variáveis no Processo para Planicidade A......................... 70

Figura 4.23: Análise do Intervalo de $95 \%$ de confiança para os quatro fatores para

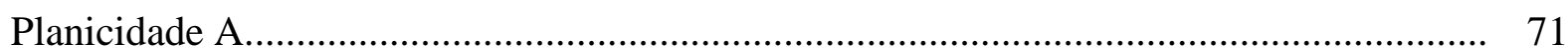

Figura 4.24: Gráfico de interação dos fatores para Planicidade A...................................... 73

Figura 4.25: Comparação da média e da dispersão das planicidades S e A........................ 74

Figura 4.26: Representação da planicidade da face do canal com a indicação da região

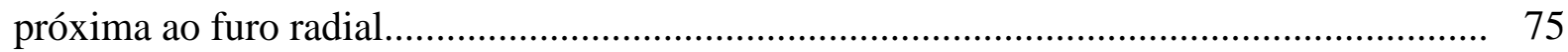

Figura 4.27: Regressão Linear entre a Planicidade S e a espessura da parede.................... 76

LISTA DE TABELASTabela 2.1: Relação dos melhores ângulos em função do material $\quad$ da $\quad$ velocidade de

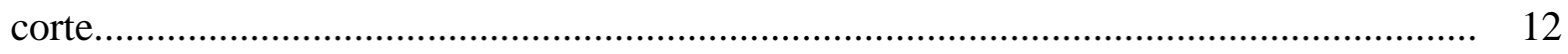

Tabela 3.1: Variáveis do estudo................................................................................. 38

Tabela 4.1: Análise ANOVA da Rugosidade $\mathrm{Ra}$ com os fatores analisados individualmente.

Tabela 4.2: Análise ANOVA da Rugosidade Ra com os fatores combinados dois a dois.

Tabela 4.3: Análise ANOVA do Perpendicularismo com os fatores analisados individualmente.

Tabela 4.4: Análise ANOVA do Perpendicularismo com os fatores combinados dois a dois.

Tabela 4.5: Análise ANOVA da Conicidade Horizontal com os fatores individuais

Tabela 4.6: Análise ANOVA da Conicidade Horizontal com os fatores combinados dois a dois. 
Tabela 4.7: Análise ANOVA da Conicidade Vertical com os fatores individuais.

Tabela 4.8: Análise ANOVA da Conicidade Vertical com os fatores combinados dois a dois.

Tabela 4.9: Análise ANOVA da Planicidade S com os fatores individuais. 62

Tabela 4.10: Análise ANOVA da Planicidade S com os fatores combinados dois a dois. 66

Tabela 4.11: Análise ANOVA da Planicidade A com os fatores individuais 68

Tabela 4.12: Análise ANOVA da Planicidade A com os fatores combinados dois s dois. 72 Tabela 5.1 - Síntese dos fatores e suas combinações que interferem em cada uma das características estudadas. 


\section{SUMÁRIO}

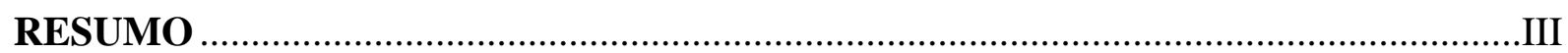

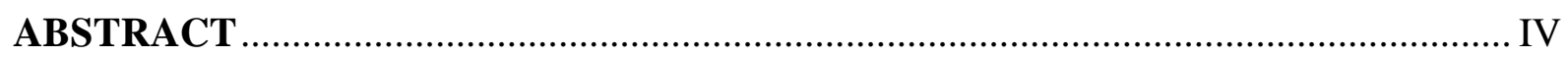

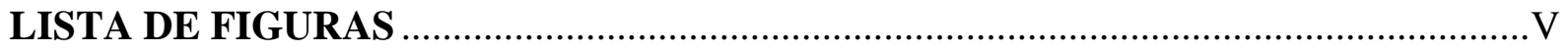

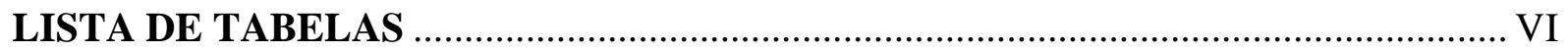

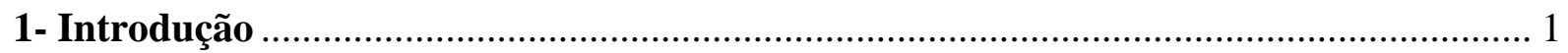

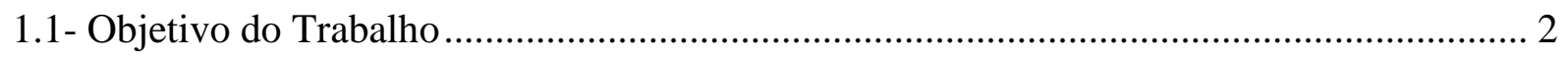

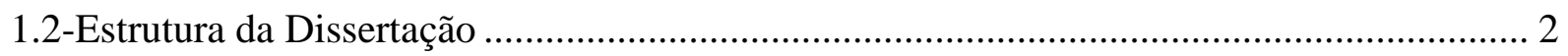

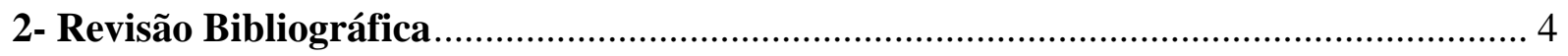

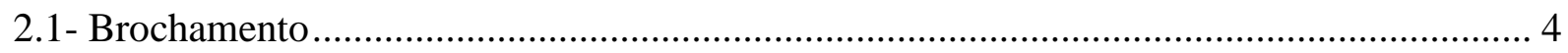

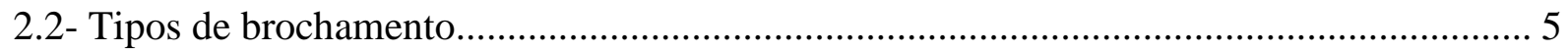

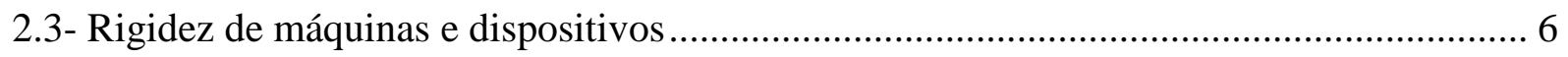

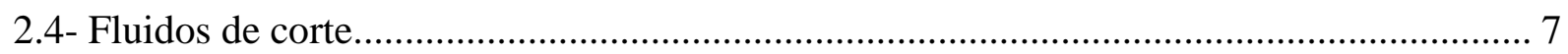

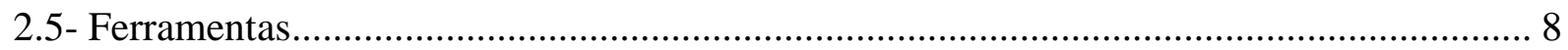

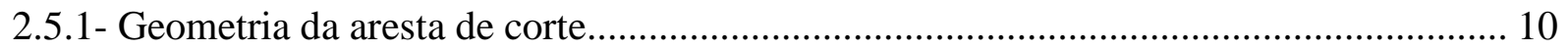

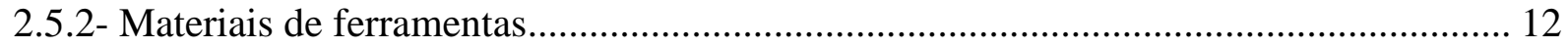

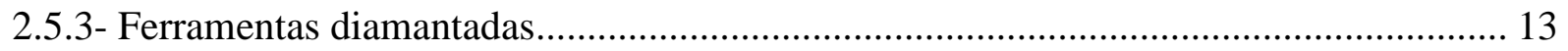

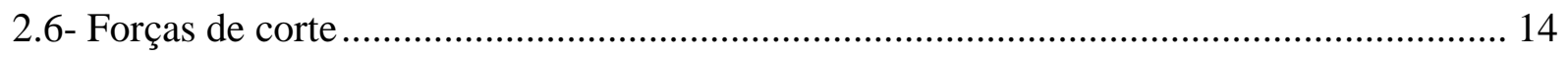

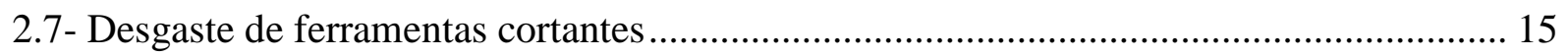

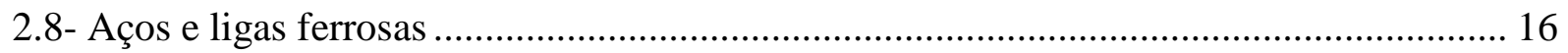

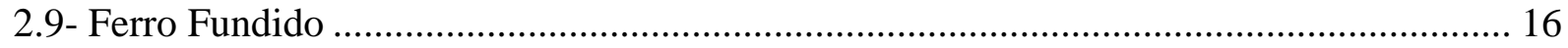

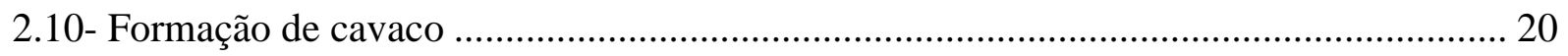

2.11- Acabamentos superficiais e geometria definida por usinagem.................................... 22

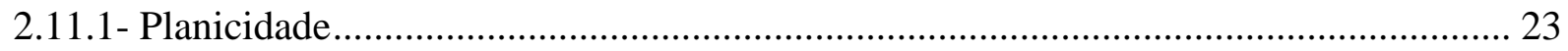

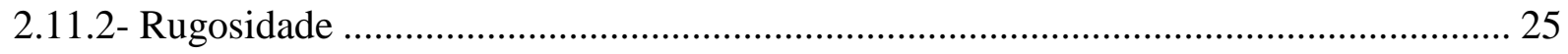


2.11.3- Métodos para medição de acabamentos superficiais (rugosidade) 26

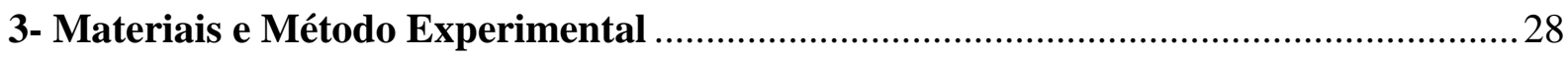

3.1- Material para experimentação ............................................................................ 28

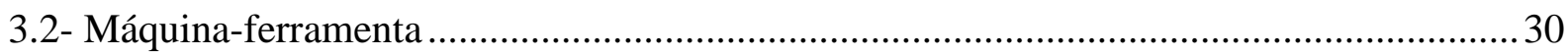

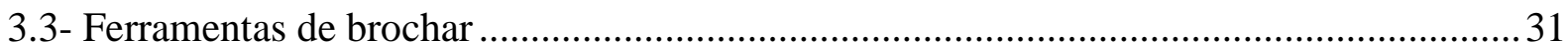

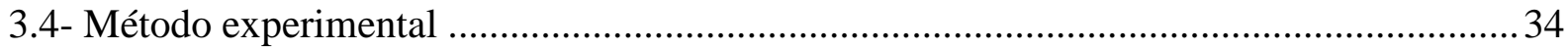

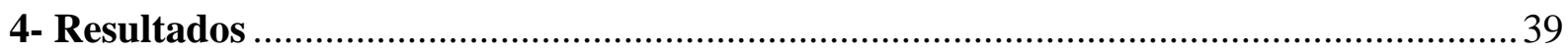

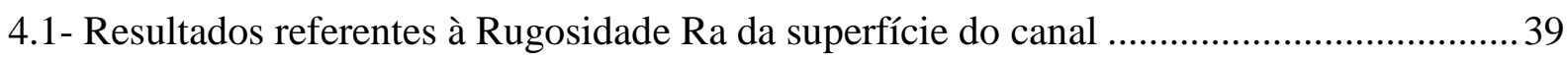

4.2- Resultados referentes ao perpendicularismo do canal............................................... 45

4.3- Resultados referentes à Conicidade Horizontal das faces do canal .................................50

4.4- Resultados referentes à Conicidade Vertical das faces do canal.....................................56

4.5- Resultados referentes a planicidade da superfície do canal próxima ao furo radial (face S)

4.5- Resultados referentes a planicidade da superfície do canal na face oposta ao furo radial

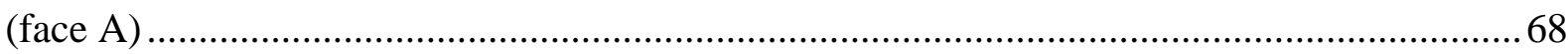

4.7- Análise comparativa entre Planicidade A e Planicidade S.............................................. 73

5- Conclusões e Sugestões para Futuros Trabalhos ........................................................ 78

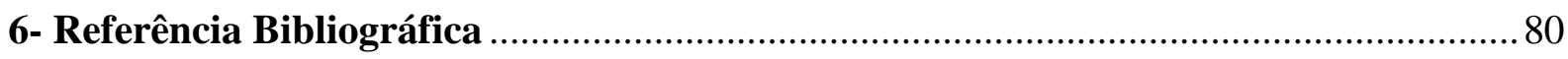





\section{1- Introdução}

O brochamento é um processo de usinagem antigo que já passou por muitas transformações, originou-se pela necessidade de calibração de furos onde ferramentas de brochar eram golpeadas em furos abertos em desbaste. As ferramentas foram sendo desenvolvidas para aplicações mais elaboradas, desta forma foi necessária a adaptação destas ferramentas em equipamentos mecânicos com maior poder de remoção de material em virtude do aumento das forças de corte.

Com o aumento da diversidade de ferramentas para aplicações diversas, o processo foi se estruturando e os equipamentos passaram a apresentar evolução, surgiram máquinas modernas com acionamento hidráulico e com diferentes direções de corte, podendo ser no sentido vertical, horizontal e helicoidal. Pode ser aplicado em usinagem interna e externa dos materiais. O acabamento superficial e geométrico pode apresentar características de acabamento fino com a aplicação de parâmetros e ferramentas adequadas para cada processo e em função do material utilizado.

Atualmente é um processo de usinagem pouco estudado devido às limitações de equipamentos e ferramentas que são empregados neste tipo de usinagem. As máquinas são muito específicas e o custo de sua construção somente se justifica para grandes produções, o que inviabiliza a aquisição deste tipo de equipamento com a única finalidade de estudar suas características. O ferramental é caro e não oferece muita versatilidade para ajustes, no entanto, as maiores evoluções do brochamento ocorreram pela intervenção dos fabricantes de ferramentas, que aprimoram os ferramentais nas indústrias e promovem a maior funcionabilidade deste processo.

Entretanto, em alguns casos, sua aplicação é entendida como eficiente e produtiva, sendo empregada até mesmo em setores industriais que necessitam de grande precisão geométrica e 
superficial, tal como indústrias automotivas que utilizam este processo para o desbaste de mancais de virabrequins, indústrias aeroespaciais na fabricação de engrenagens especificas e fabricantes de compressores herméticos, onde o processo é utilizado na abertura de canais helicoidais para a lubrificação de mancais.

\section{1- Objetivo do Trabalho}

O objetivo deste trabalho é analisar a interferência de alguns parâmetros de usinagem no acabamento superficial e na geometria de peças submetidas ao brochamento. O material utilizado para os testes é o ferro fundido cinzento que está bastante presente na atual indústria de transformação.

Através de métodos estatísticos é possível determinar a influência de alguns parâmetros de usinagem, sendo que neste caso foi analisado o acabamento superficial e geométrico de peças confeccionadas pelo processo de brochamento em acabamento. Este processo não é um dos mais utilizados, porém está presente em muitas indústrias e por isso, há a necessidade de se encontrar os melhores parâmetros de usinagem, e por conseqüência, melhorar a produtividade e a qualidade das peças fabricadas.

\section{2-Estrutura da Dissertação}

Este trabalho está estruturado em 6 capítulos:

- Capítulo 1: Uma breve introdução sobre a operação de brochamento.

- Capítulo 2: Revisão Bibliográfica do assunto informando o surgimento do brochamento e sua evolução, apontando vantagens e limitações deste processo de usinagem juntamente com os tipos de equipamentos. Contém também citações sobre os ferramentais característicos e tipos de geometria e acabamento superficial determinado pelo processo. 
- Capítulo 3: Materiais e Método Experimental, destacando o equipamento utilizado e seus principais dispositivos necessários para a realização do trabalho. Descreve-se a metodologia utilizada, material utilizado no experimento, a forma como as peças foram produzidas e o sistema de aquisição de dados.

- Capítulo 4: Resultados e Discussões apresentados com o foco na qualidade da peça e as melhores condições de usinagem.

- Capítulo 5: Conclusões do trabalho e sugestões para futuros trabalhos.

- Capítulo 6: Bibliografia. 


\section{2- Revisão Bibliográfica}

\section{1- Brochamento}

A operação de brochamento surgiu em 1873 nos EUA, como um processo evolutivo da operação de forjamento que era amplamente utilizada pelos ferreiros. Eles utilizavam tipos de punção sem dentes que eram golpeados na peça, onde eram usados para dar formas e tamanhos diferentes aos furos. As brochas passaram então a possuir dentes e esta operação passou a ser caracterizada como operação de usinagem e denominada por brocheamento ou brochamento (FREIRE, 1978).

Em 1882 surgiram as primeiras máquinas de brochar externamente, as quais eram acionadas por correias e utilizadas principalmente para abrir rasgos de chavetas. Em 1914 foram construídas as máquinas horizontais de duplo cabeçote com velocidade de 2,5 m/min. Posteriormente, foram surgindo máquinas destinadas ao brochamento de ranhuras helicoidais e, em 1921 apareceram brochadeiras com maior velocidade de corte com a utilização de cremalheira (nesta época também surgiu a primeira brochadeira vertical). Estas máquinas atingiam velocidade de corte de 5,5 m/min. No ano de 1923 as máquinas foram equipadas com acionamento hidráulico e com isto eram capazes de atingir uma velocidade de corte de 7 m/min. Somente em 1925 este processo passou a ser intensamente empregado na produção seriada e a evolução continuou com o aumento da capacidade e eficiência das máquinas (FREIRE, 1978).

Historicamente, o processo de brochamento se originou de experiências baseadas em “tentativas e erros", em que o objetivo era atingir as características geométricas e superficiais da peça brochada, sem a preocupação de tornar o processo viável economicamente. Os aspectos econômicos e produtivos deste processo foram desenvolvidos posteriormente pelos fabricantes de ferramentas (SUTHERLAND, SALISBURY e HOGEI, 1997), que concentraram 
seus esforços na melhoria do desempenho da ferramenta por meio da mudança da geometria da própria ferramenta, aumentando a sua vida e reduzindo o tempo de usinagem, abrindo com isso, caminho para a viabilização do processo de brochamento.

O brochamento pertence ao método de fabricação denominado "com remoção de cavacos" conforme DIN 8580, devido ao fato de a ferramenta gerar formas geométricas de corte bem definidas. A ferramenta é fabricada com um grande número de arestas de corte dispostas em seqüência, crescente na altura ou largura. Remove o material por meio do movimento relativo entre ferramenta e peça. Neste processo a peça é fixada em um dispositivo e o avanço está na própria ferramenta. A brochadeira produz um movimento de translação que é o movimento principal de corte, podendo ter direção vertical ou horizontal (PAHL, 1984).

A possibilidade de realizar uma operação de usinagem em que, em um único passe, podem ser executadas as operações de desbaste, semi-acabamento e acabamento desde peças com acabamento superficial simples até as formas mais complexas, torna o brochamento um processo de usinagem único, com alta produtividade e excelente qualidade superficial das peças usinadas (MO et al, 2005).

Atualmente, o brochamento é um processo de usinagem amplamente utilizado para a formação de perfís em superfícies internas ou externas, com boa integridade superficial e com exigências de geometrias perfeitas, normalmente utilizado em indústrias aeroespaciais e de turbo propulsores. As condições das ferramentas do brochamento têm grande influência na determinação do acabamento superficial das peças, que são produzidas por este processo e com aplicações particularmente em peças rotativas de motores ( AXINTE et al, 2003).

\section{2- Tipos de brochamento}


De acordo com a construção da máquina, o brochamento pode ser classificado como horizontal ou vertical, onde o que determina esta característica é a direção do movimento da ferramenta. $\mathrm{O}$ modo como a ferramenta é projetada sobre a peça classifica o esforço de corte do equipamento como corte por tração ou compressão. Estas variações tornam a operação de brochamento bastante específica e recomendada para produção seriada (FREIRE, 1978).

As brochadeiras do tipo vertical somam cerca de $60 \%$ de todas as máquinas produzidas, sendo que esta porcentagem se divide entre as verticais internas e verticais externas em proporções muito próximas. A movimentação da ferramenta geralmente é realizada por sistema hidráulico, principalmente em usinagem de metais, entretanto, existem máquinas que são construídas com acionamento eletromecânico (NELSON, 2001).

As peças podem ser brochadas internamente ou externamente com diversos perfis, de modo que as principais limitações para este processo são duas. A primeira é que as peças sejam planas na direção do corte, já a segunda é que as superfícies a serem usinadas não possuam ressaltos que possam interferir no movimento de corte da ferramenta. $O$ brochamento também pode ser helicoidal onde, além do movimento de translação, existe o movimento de rotação da ferramenta ou da peça (PAHL, 1984).

\section{3- Rigidez de máquinas e dispositivos}

As forças de corte durante uma operação de usinagem, qualquer que seja a operação, geram vibrações com freqüências elevadas, estas vibrações se propagam pelos componentes da máquina e por consequiência atingem as peças usinadas. Uma vibração perceptível nas operações de usinagem é usualmente chamada de "trepidação", podendo ser muito ruidosa e indesejável por causar danos à máquina e prejudicar o acabamento das superfícies usinadas, formando as "marcas de trepidação".

Podemos afirmar que há algumas práticas normais para diminuir trepidações. São elas: 
$\checkmark$ o uso de ferramentas mais robustas;

$\checkmark \quad$ a alteração da velocidade de corte, do avanço ou da profundidade da usinagem;

$\checkmark$ a modificação da forma da ferramenta, sendo que esta alteração normalmente é feita de forma à reduzir o comprimento da aresta cortante em contato com o material.

Embora haja artifícios para evitar falhas de usinagem geradas por pouca rigidez do equipamento, este deve ser robusto o suficiente para absorver as vibrações inerentes ao processo de usinagem, de modo a garantir o acabamento superficial (DOYLE, 1978).

\section{4- Fluidos de corte}

O fluido de corte é uma solução aquosa com uma porcentagem de óleo, sendo esta porcentagem determinada de acordo com a aplicação (TRENT, 1996). Atualmente os óleos minerais estão sendo substituídos por óleos sintéticos que, apesar de serem mais caros, apresentam melhores resultados e compensam o investimento.

Os benefícios do fluido refrigerante em processos de usinagem podem ser dispostos em quatro pontos (DERFLINGER, BRÄNDLE e ZIMMERMANN, 1999):

- efeito lubrificante: redução do atrito na região de contato entre a peça e a ferramenta;

- efeito dispersivo: remoção dos cavacos da área de corte e do interior do equipamento;

- efeito refrigerante: dissipar o calor gerado na região de contato peça-ferramenta de corte;

- efeito anti-corrosivo: aditivos químicos reduzem possibilidade de corrosão de partes metálicas (peça ou equipamento).

Em operações de brochamento, onde as condições de corte são severas, faz-se necessário o arrefecimento e a lubrificação do corte, considerando-se sempre o tipo de material a ser usinado e sua usinabilidade. Para a usinagem de materiais ferrosos é indicada a utilização de óleos solúveis na proporção de 0,5 a 30\% ou óleos minerais (FREIRE, 1978). 


\section{5- Ferramentas}

As ferramentas de usinagem podem ser classificadas em ferramentas de uma única aresta cortante e de múltiplas arestas cortantes. As ferramentas com mais de uma aresta de corte se comportam como uma combinação de ferramentas de uma única aresta cortante. Desta forma, os fatores que caracterizam as ferramentas de múltiplas arestas cortantes são as mesmas de determinam as de única aresta (DOYLE, 1978).

No brochamento, as ferramentas utilizadas normalmente possuem várias arestas de corte (dentes da ferramenta), e são dispostas em seqüência onde a dimensão de cada dente posterior é ligeiramente maior que o anterior, o que possibilita uma remoção do material proporcional para cada dente. Em brochamento onde existe um pré-furo, os primeiros dentes apresentam menor dimensão que o furo inicial, permitindo desta forma a livre passagem da ferramenta antes de iniciar o corte propriamente dito (FREIRE, 1978).

O ferramental utilizado em brochamento normalmente tem custo elevado, porém pode-se apontar uma grande vantagem com relação a outros processos, que é justamente a possibilidade de combinar ferramentas com características de desbaste juntamente com ferramentas de acabamento. Esta flexibilidade de composição de ferramentas pode gerar menores ciclos de usinagem sem perda de qualidade da peça fabricada (KRAR, 1997).

A Figura 2.1 mostra detalhes de arestas de corte em uma ferramenta de brochamento. 

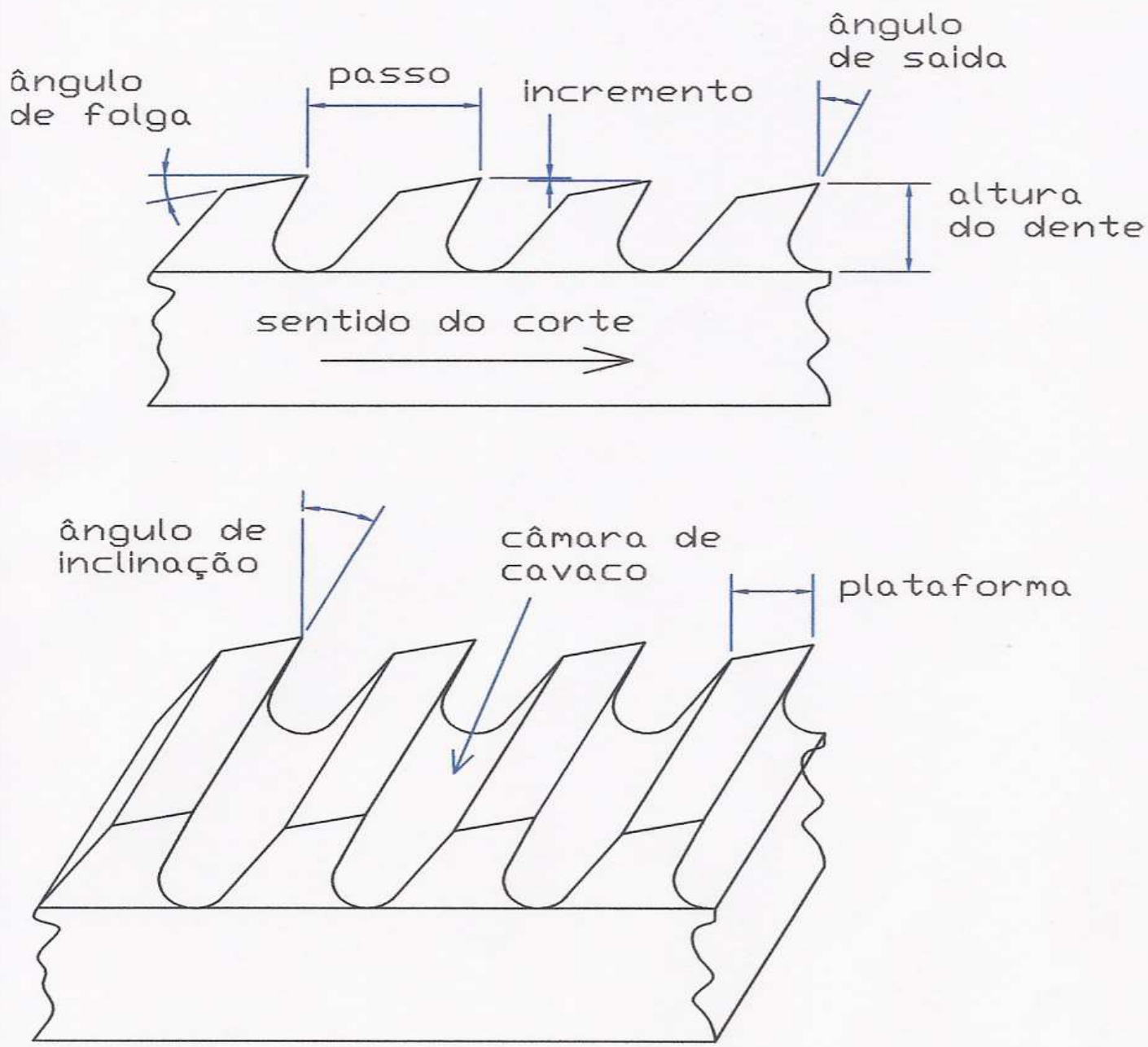

gura 2.1 - Geometria de brocha de corte

Na Figura 2.1 podemos ver as principais características de uma ferramenta de corte. Os ângulos de folga e de saída normalmente são determinados em função do material a ser usinado. O passo, o incremento e a câmara de cavaco são projetados em função da remoção do material. O ângulo de inclinação e a plataforma são determinados em função da força de corte que a ferramenta será submetida.

O ângulo de inclinação dos dentes, quando diferente de zero, certamente encarece a fabricação e a afiação da ferramenta, mas em muitas situações, esta inclinação é fundamental para o processo. Ângulos diferentes de zero apresentam algumas vantagens (PAHL, 1984): 
$>$ A entrada e a saída da ferramenta na peça ocorrem de maneira suave e sem batidas, gerando menores amplitudes de vibração e baixa ressonância na usinagem. Sem a inclinação dos dentes estes problemas são potencializados, principalmente em usinagens de superfícies retangulares e normais à direção do corte;

A força de corte dinâmica pode ser diminuída através da determinação correta do ângulo de inclinação e do passo, sendo que estas características estão relacionadas com as dimensões da superfície a brochar, que também podem gerar pequenas amplitudes de vibração e baixa ressonância;

É fundamental quando existe a necessidade de alta qualidade de forma e dimensão da peça usinada. Esta qualidade pode ser mais facilmente atingida com a inclinação dos dentes, porque a existência de uma pequena resultante de força lateral irá determinar a redução das folgas, que por sua vez podem ser encontradas nas guias das colunas ou do porta ferramentas;

A inclinação dos dentes promove um melhor escoamento dos cavacos para a lateral do corte, reduzindo o atrito destes com a superfície da peça.

\subsection{1- Geometria da aresta de corte}

De acordo com a aplicação da ferramenta, o dente pode apresentar características diferentes. Dentes para desbaste, normalmente apresentam a aresta de corte formada unicamente pelos ângulos de saída e de folga. Em ferramentas para acabamento, a aresta de corte apresenta uma área de contato posterior à aresta de corte, sendo que esta área é paralela a direção de corte e é conhecida como filete. Este filete é importante para o acabamento fino e a calibragem de superfícies (RUFFINO, 1973).

Com geometria diferente do convencional, o dente de alisamento não apresenta ângulo de cunha e o ponto de contato com a peça é circular, sendo sua principal função promover um 
polimento e compactação da superfície brochada. Em brochamento interno de canais paralelos, estes dentes podem ser substituídos por um sistema de roletes que, quando montados em suporte adequado e específico, simulam a atuação dos dentes de alisamento. $\mathrm{Na}$ Figura 2.2 temos a representação dos principais perfis de ferramentas de brochar.

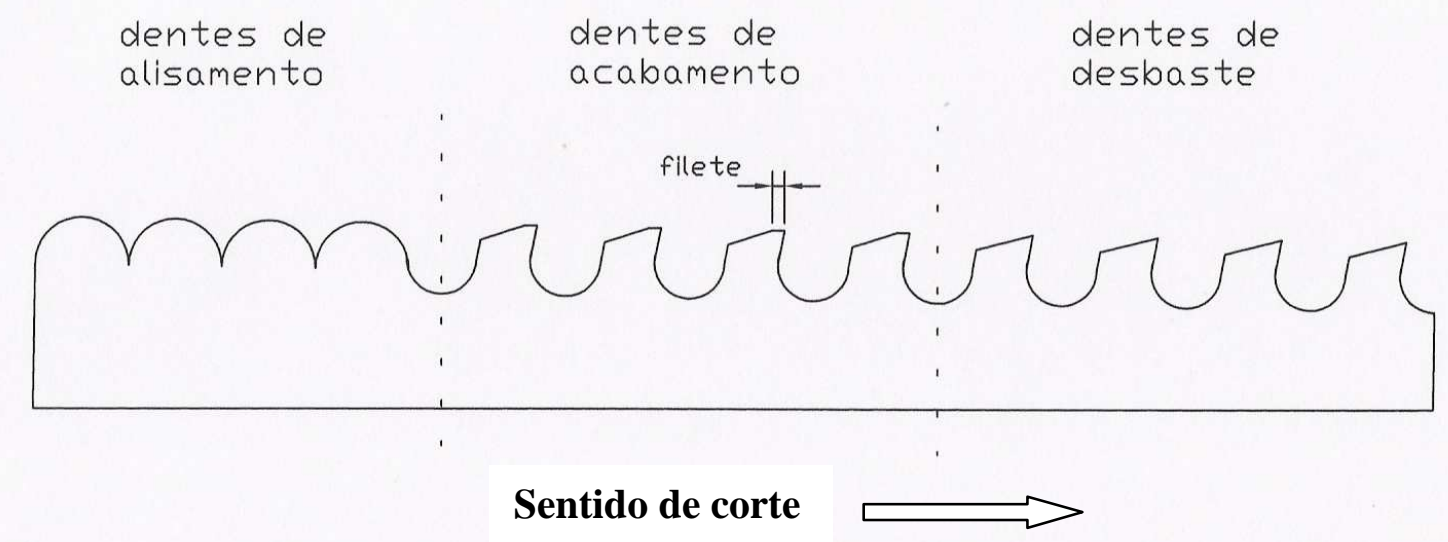

Figura 2.2 - Diferentes perfis de arestas.

Na Figura 2.2 está a representação de três tipos de perfis empregados em ferramentas de brochamento. Os dentes de desbaste, dentes de acabamento com a indicação do filete e dentes de alisamento que apresenta um perfil circular.

Para a construção de ferramentas de brochar, os ângulos de saída e de folga são determinados principalmente em função do material da peça e da velocidade de corte. Com o aumento da velocidade de corte, se faz necessário aumentar o ângulo de folga, e desta forma, reduzir o acúmulo de material sobre a superfície deste ângulo. Pode-se também aumentar o ângulo de saída para melhorar o enrolamento do cavaco. Valores de referência para construção de ferramentas podem ser observados na Tabela 2.1, que relaciona os ângulos da aresta de corte em função da velocidade e do material a ser usinado (PAHL, 1984). 
Tabela 2.1 - Relação dos melhores ângulos em função do material e da velocidade de corte (PAHL, 1984).

\begin{tabular}{|c|c|c|c|c|}
\hline \multirow{2}{*}{ Material da peça } & \multicolumn{2}{|c|}{ Velocidade de corte até $12 \mathrm{~m} / \mathrm{min}$} & \multicolumn{2}{|c|}{ Velocidade de corte de 12 a $18 \mathrm{~m} / \mathrm{min}$} \\
\hline & ângulo de folga & ângulo de saída & ângulo de folga & ângulo de saída \\
\hline $\begin{array}{l}\text { Materiais de } \\
\text { cavacos curtos } \\
\text { (FoFo) }\end{array}$ & $2^{\circ}$ & $15^{\circ} \mathrm{a} 18^{\circ}$ & $3^{\circ} \mathrm{a} 4^{\circ}$ & $15^{\circ} \mathrm{a} 20^{\circ}$ \\
\hline $\begin{array}{l}\text { Materiais de } \\
\text { cavacos longos }\end{array}$ & $3^{\circ} \mathrm{a} 4^{\circ}$ & $15^{\circ} \mathrm{a} 20^{\circ}$ & $4^{\circ}$ a $5^{\circ}$ & $20^{\circ}$ a $25^{\circ}$ \\
\hline
\end{tabular}

Em operações de brochamento interno, a direção de corte é dada pelo sentido da velocidade de corte, que por sua vez está na mesma direção do eixo da brocha em brochamento cilíndrico, ou na direção do magazine porta-ferramentas em brochamento de superfícies paralelas. O avanço da brocha é determinado pelo aumento progressivo das dimensões de cada dente, ou seja, o incremento é o próprio avanço por dente. Portanto, podese afirmar que a direção do avanço é perpendicular à direção de corte (RUFFINO, 1973).

\subsection{2- Materiais de ferramentas}

O material com que as ferramentas de corte são fabricadas depende de alguns fatores do processo de usinagem (GONÇALVES, 1995), sendo que os principais são:

Material da peça a ser usinado;

Natureza da operação de usinagem;

Condição da máquina operatriz;

Forma e dimensões da própria ferramenta;

Emprego de refrigeração ou lubrificação;

Grandezas de corte; 
Condições de usinagem.

A partir das informações sobre a usinagem, define-se o material para a construção da ferramenta, que pode ser de aço ao carbono, aço rápido, aço semi-rápido, liga fundida, metal duro, metal duro revestido, material cerâmico, diamante, entre outros. Os aços rápidos são ligas $\mathrm{F}_{\mathrm{e}}-\mathrm{C}$ altamente ligadas, sendo que são estas ligas que determinam características fundamentais na ferramenta de corte, como por exemplo resistência ao desgaste, dureza a quente e tenacidade (GONÇALVES, 1995).

O fato de o brochamento apresentar baixas velocidades de corte, geralmente abaixo de $0,5 \mathrm{~m} / \mathrm{s}(30 \mathrm{~m} / \mathrm{min})$, as temperaturas de corte atingem de 200 a $600^{\circ} \mathrm{C}$, com isto, o emprego do aço rápido para confeccionar este tipo de ferramenta é muito comum, já que este material mantém a mesma dureza até $600^{\circ} \mathrm{C}$ de temperatura de trabalho, tem custo baixo e boa tenacidade, de forma que esta última característica favorece a usinagem dos materiais em situações com corte interrompido (PAHL, 1984).

\subsection{3- Ferramentas diamantadas}

Os materiais usados na fabricação de ferramentas abrasivas são geralmente classificados por naturais ou sintéticos. Entre os naturais estão incluídos o diamante, o corundun e o esmeril. Estes materiais se encontram em depósitos naturais, podendo ser extraídos e processados para o uso com poucas alterações.

Os abrasivos sintéticos são produtos obtidos a partir de alterações de materiais brutos ou precursores químicos. Como exemplos de abrasivos sintéticos, temos o carbureto de silício, a alumina e o diamante sintético. Os abrasivos sintéticos são mais utilizados nas indústrias por apresentarem menores variações de suas propriedades mecânicas, mesmo quando aplicados em operações de usinagem (ALMEIDA, 2002). 
Além de brochas de corte, existem também brochas para brunimento, onde a finalidade é melhorar o acabamento da superfície que foi brochada. As brochas de brunimento, ou alisamento, reduzem os riscos gerados pela ferramenta de corte e promovem o polimento da superfície brochada. Em brochas para brunimento ou alisamento, os dentes não têm a finalidade de cortar o material, e sim de comprimir e esfregar a superfície do material (DOYLE, 1978). Atualmente utiliza-se diamante sintético para a construção destas brochas para brunimento de superfícies, onde são dimensionadas com grãos pequenos e de baixo poder de remoção de material.

\section{6- Forças de corte}

A força de corte na usinagem dos metais é um fenômeno periódico. As forças de corte aumentam quando a ferramenta penetra no material, podendo causar uma pequena deflexão na ferramenta. As forças diminuem momentaneamente quando ocorre a ruptura ou o cisalhamento do material usinado (remoção do cavaco), sendo que esta diminuição das forças determina o recuo elástico da ferramenta para a posição original.

Mesmo nos cortes aparentemente contínuos, em virtude da variação da força de corte, podem ocorrer pequenas flexões da ferramenta ou da aresta de corte da ferramenta, onde a variação das forças de corte ocorre em função da velocidade relativa entre a ferramenta e a peça (DOYLE, 1978).

No momento do corte, o corpo da ferramenta é forçado a remover o material a uma velocidade constante. Quando se inicia a penetração, a aresta de corte ou a ponta da ferramenta cede elasticamente, isto ocorre devido à resistência crescente que a ferramenta encontra no decorrer da usinagem e, de forma inversa, a velocidade relativa entre a aresta cortante e a peça decresce proporcionalmente. Com baixas velocidades de corte, as forças aumentam e a ferramenta é ainda mais solicitada. 
Quando o momento fletor na ferramenta se torna suficientemente grande, a ferramenta volta à sua forma original e este movimento provoca um aumento da velocidade relativa entre a aresta cortante e a peça, reduzindo desta forma as forças de corte. A ferramenta cede elasticamente até alcançar um estado de equilíbrio e por consequiência a velocidade relativa diminui e as forças de corte começam a crescer. A partir deste ponto se inicia um novo ciclo (DOYLE, 1978).

\section{7- Desgaste de ferramentas cortantes}

A capacidade de remoção de material por uma ferramenta varia de acordo com o desgaste das suas superfícies de corte. A mudança da própria geometria da ferramenta, que é uma das conseqüências da alteração dos ângulos, pode ocasionar uma deficiência nas características de usinagem, gerando uma redução do poder de corte, que promove o aumento das forças de interação entre o material e a ferramenta. Segundo experimentos, este aumento pode chegar em até $30 \%$ da força normal e determinar prejuízos qualitativos na superfície usinada, este desgaste é ocasionado principalmente por três características (PAHL, 1984):

$>$ peça usinada - tipo de material, estrutura interna, resistência mecânica e condição da superfície;

ferramenta - material, dureza, tenacidade, geometria de corte e qualidade da afiação;

máquina - velocidade de corte, refrigeração, rigidez da máquina e seus dispositivos.

Devido à necessidade de otimização das ferramentas de brochamento e de controlar a qualidade da peça usinada, é possível identificar o mau funcionamento de uma ferramenta através da medição da força de corte gerada durante o ciclo de brochamento. O desgaste das arestas, a alteração da geometria de corte ou o lascamento de algum dos dentes determina 
diferentes forças de corte, onde esta variação da força de corte pode ser percebida através de um dinamômetro, possibilitando a retirada da ferramenta antes que esta tenha sua reafiação comprometida pelo alto desgaste dos dentes (AXINTE, 2005).

\section{8- Aços e ligas ferrosas}

Os aços são compostos basicamente de ferro e carbono, sendo que a proporção de carbono nestes materiais varia entre 0,05 e 1,5\%. A adição de outros elementos químicos específicos, em quantidades determinadas, formam as ligas de aço. Em virtude das muitas combinações químicas possíveis e dos tratamentos térmicos, o aço adquire a característica de material bastante versátil na indústria. As aplicações podem estar relacionadas com a condução de eletricidade ou de magnetismo, resistências à corrosão e propriedades mecânicas (NELSON, 2001).

O fato do aço se apresentar com diversas composições torna sua usinabilidade muito difícil em alguns casos. Aços que apresentam concentração de carbono abaixo de 0,3\% são altamente dúcteis, onde esta ductilidade impossibilita a quebra do cavaco em operações como torneamento e furação. Na situação inversa, em que o aço apresenta alta dureza em virtude da composição química do material ou de tratamentos térmicos, a usinagem também se torna crítica em operações de corte devido à dificuldade de remoção do cavaco. O ferro fundido difere do aço por possuir maior concentração de carbono em sua composição química, pois sua porcentagem de carbono varia de 1,7 a 4,5\% (NELSON, 2001).

\section{9- Ferro Fundido}


Os ferros fundidos são de extrema importância para várias aplicações na indústria e isto ocorre em função das diferentes propriedades mecânicas que este material apresenta mediante sua composição química. A adição de elementos de liga ou a alteração de suas microestruturas através de tratamentos térmicos, também determinam diferentes propriedades mecânicas (FERRARESI, 1977), no entanto, a usinabilidade está ligada a inúmeras variáveis.

Algumas destas diferenças na usinabilidade de materiais com a mesma composição química ainda não podem ser totalmente explicadas, já que pequenas diferenças na composição química, tratamento térmico e nodularidade podem ocasionar diferenças imperceptíveis nas propriedades mecânicas, mas efeitos significantes na usinabilidade (COHEN e VOIGT, 2003).

A composição química do ferro fundido é basicamente determinada por ligas de ferrocarbono, onde o teor de carbono deve estar sempre acima de $2 \%$. O silício também é um elemento fundamental na composição do ferro fundido, sendo que, em determinadas composições pode estar presente em proporções até maiores que a do próprio carbono. Outros elementos que normalmente são encontrados na composição dos ferros fundidos são: manganês, fósforo e enxofre (CHIAVERINI, 1984).

A presença de pequena quantidade de grafite na composição do ferro fundido dúctil é que caracteriza sua boa usinabilidade (MORWANGA et al., 2000). O grafite está presente no ferro fundido dúctil sob a forma de nódulos esferoidais, ao invés de flocos como é encontrado nos ferros fundidos cinzentos. Estes nódulos são formados pela adição de ligas de magnésio ou cério (IMASOGIE, AFONJA e ALI, 2000) em composições de ferro fundido com baixa concentração de enxofre que, após a reação química, o carbono é liberado e irá formar os nódulos de grafite.

$\mathrm{Na}$ estrutura dos ferros fundidos a grafita é o elemento mais importante (CHIAVERINI, 1984), sendo esta que determina as características mecânicas deste material. 
A quantidade de grafita é determinada pelo teor de carbono e pela presença do silício, de maneira que o silício é o elemento químico que favorece a decomposição do carboneto de ferro.

A velocidade de resfriamento durante a solidificação do ferro fundido também determina a quantidade de grafita na composição do material e, por conseqüência, promove a alteração nas propriedades mecânicas. Encontra-se também na estrutura dos ferros fundidos a ferrita, a cementita e a perlita, sendo todos estes também determinados pelas concentrações dos elementos químicos e pela velocidade de resfriamento do material.

Os ferros fundidos podem se apresentar normalmente em quatro tipos (DINIZ et. al, 1999), cada qual com suas propriedades distintas e determinados pela estrutura e composição química. Podem ser do tipo cinzento, maleável, nodular ou branco, sendo esta a seqüência do ferro fundido de melhor condição de usinagem para o de propriedades mecânicas com as piores condições de usinabilidade.

- O ferro fundido cinzento pode conter até 3\% de silício em sua composição, elemento este que reduz a formação de carbeto (ou carboneto) de ferro duro e aumenta a quantidade de grafita que se apresenta em forma de lâminas. Esta grafita em forma de lâminas determina uma melhor condição de usinagem em relação aos demais tipos de ferro fundidos;

- O ferro fundido maleável é um ferro fundido branco que sofreu tratamento térmico para redução dos carbonetos de ferro e das grafitas lamelares. Seu tratamento térmico transforma as grafitas lamelares em esferoidais, sendo estas responsáveis pela estrutura mais dúctil e tenaz do ferro fundido maleável que determina uma boa usinabilidade;

- O ferro fundido nodular caracteriza-se pela forma esferoidal das grafitas. A grafita esferoidal é determinada pela adição de magnésio na composição do ferro fundido, 
sendo que este elemento tem como princípio inibir o teor de enxofre para definir esta forma de grafita. Esta característica torna o ferro fundido nodular mais resistente que o cinzento, porém sua usinabilidade tem um grau semelhante a do cinzento;

- O ferro fundido branco é extremamente duro e quebradiço, sendo tais características determinadas pela baixa quantidade de silício em sua composição que, de forma contrária ao que ocorre no ferro fundido cinzento (a porcentagem baixa de silício na composição do material), viabiliza a formação de carbonetos de ferro em grande proporção e, por consequiência, gera um teor extremamente baixo de grafita lamelar. Estas características tornam sua usinagem bastante difícil.

O ferro fundido de maior aplicação nas indústrias é o ferro fundido cinzento, que apresenta como características básicas:

$\checkmark$ Fácil fusão e modelagem;

$\checkmark$ Boa resistência mecânica;

$\checkmark$ Excelente usinabilidade;

$\checkmark$ Boa resistência ao desgaste;

$\checkmark$ Boa capacidade de amortecimento.

Os tipos maleáveis e nodulares também são bastante utilizados, no entanto o tipo branco tem suas aplicações mais restritas devido à elevada dureza e resistência ao desgaste. Estas características do ferro fundido tipo branco é determinada pela alta quantidade de cementita em sua estrutura (DINIZ, 1999).

A usinabilidade não é uma propriedade intrínseca do material, mas sim um resultado da interação do metal com a operação de usinagem. As condições de usinagem são estabelecidas para cada tipo de material e ferramenta. $\mathrm{O}$ avanço e a velocidade são limitados pelo calor gerado pelos atritos e pela deformação plástica do cavaco. Quanto maior a 
usinabilidade do material da peça e a resistência ao desgaste do material da ferramenta, maiores podem ser os avanços e as velocidades de corte (BAPTISTA, 2002).

Principalmente na usinagem de materiais ferrosos, devido ao atrito e a alta temperatura gerada na usinagem, deve-se utilizar os fluidos de corte sempre que possível, preferencialmente os que têm ação lubrificante e refrigerante. A profundidade de corte é um fator que limita o avanço e a velocidade de corte. Em operações de acabamento, de forma contrária ao que ocorre com as operações de desbaste, devem ser utilizados os avanços menores e velocidades maiores, sendo desta forma ser possível atender as baixas especificações de rugosidade superficial e a alta precisão dimensional (BAPTISTA, 2002).

Em qualquer trabalho de usinagem a produtividade de um equipamento de usinagem depende dos avanços e das velocidades de corte. A eficiência de um processo depende da redução dos tempos de fabricação e o aumento da velocidade de corte pode atingir este objetivo, entretanto, as condições mais econômicas de usinagem dependem também de outros fatores, tais como custos de preparação e tempo de colocação das ferramentas nas máquinas (BAPTISTA, 2002). Os parâmetros devem ser otimizados para uma usinagem eficiente e com baixo custo.

Durante a usinagem do ferro fundido, quando na utilização de condições adequadas de corte do material, percebe-se que o cavaco resultante se apresenta em forma de lascas ou pedaços, isto ocorre devido à sua estrutura frágil. Esta forma de cavaco é extremamente interessante porque viabiliza seu armazenamento, reduz possibilidades de acidente e não interfere no acabamento superficial da peça usinada (DINIZ, 1999).

\subsection{0- Formação de cavaco}


Apesar da usinagem de materiais ferrosos já ser efetuada há vários séculos, os mecanismos de formação de cavaco ainda não estão totalmente entendidos. Apenas no último século, alguns pesquisadores se ocuparam de forma mais intensiva em entender o funcionamento destes mecanismos. Tanto a análise de tensões, formas de cavacos, fatores de recalque e análises de raízes de cavaco são encontrados dominantemente para aços de baixa liga, no entanto, para o ferro fundido estas informações ainda não são totalmente conhecidas (LUCAS, 2003).

Para ferros fundidos foram encontradas poucas informações sobre os mecanismos de formação de cavacos. Observa-se que, para ferramentas com certo desgaste, é mais evidente a formação de pontos de aderências sobre a aresta de corte. A partir da área de contato entre o cavaco e a ferramenta, em associação com as componentes da força de usinagem, são estabelecidas as tensões de compressão e de cisalhamento médias na interface cavaco ferramenta (LUCAS, 2003).

As propriedades mecânicas dos materiais propiciam tipos e formas características de cavacos (GONÇALVES, 1995), entretanto, as condições do processo na formação deste cavaco podem dificultar a remoção do material ou alterar a forma e o tipo do cavaco. Os meios de alteração da forma do cavaco estão relacionados com o ângulo de saída e com o ângulo de inclinação da ferramenta ou da aresta de corte.

A forma e o tipo do cavaco também pode ser determinado pela ação de dispositivos quebra-cavaco, de modo que estes podem ser implementados na geometria de algumas ferramentas para melhorar a remoção do cavaco(BOOTHROYD, 1989). A Figura 2.3 mostra formas e tipos de cavacos. 


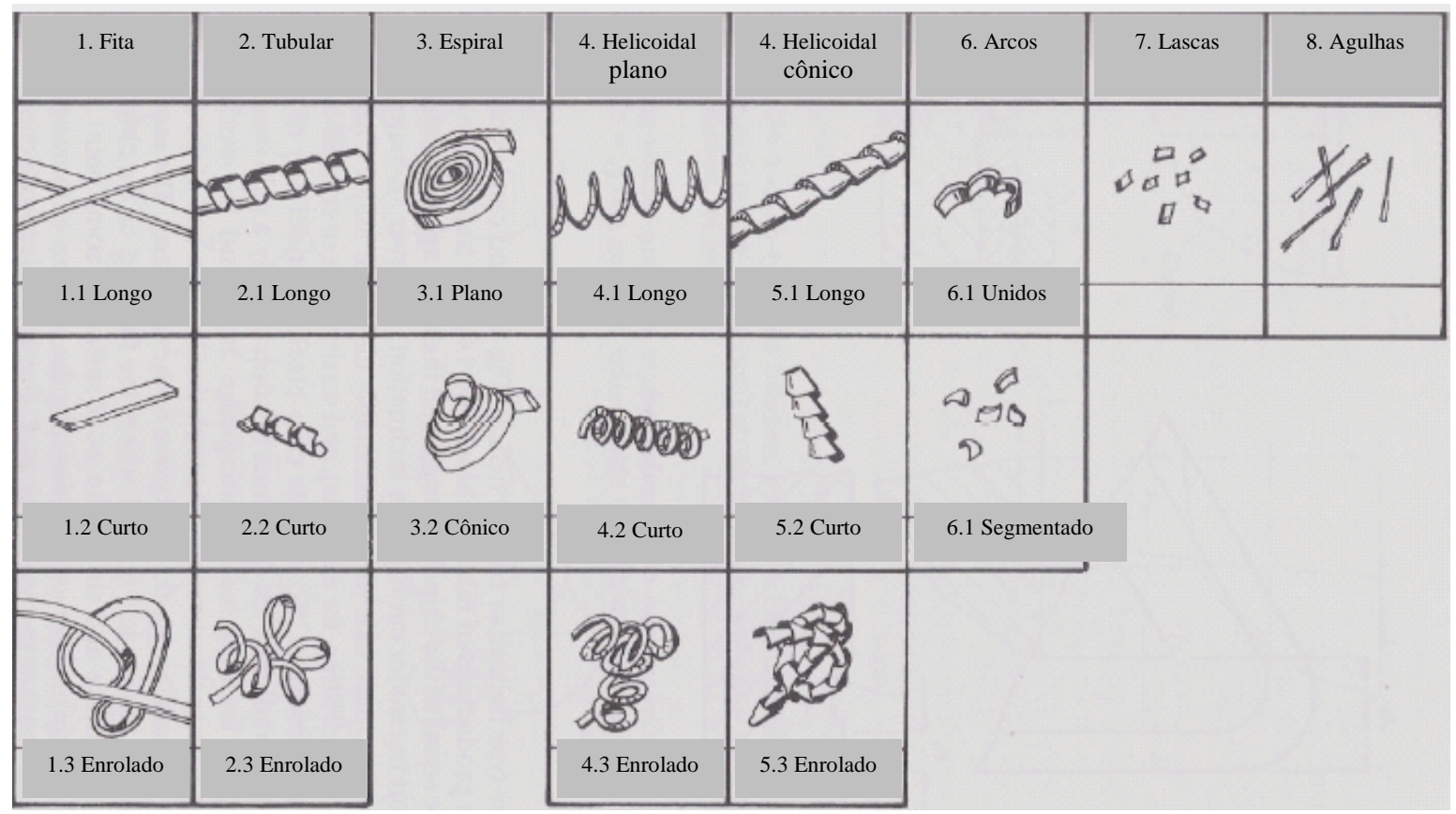

Figura 2.3 - Tipos e formas de cavacos (BOOTHROYD, 1989).

\subsection{1- Acabamentos superficiais e geometria definida por usinagem}

No campo da manufatura, o acabamento superficial é considerado fundamental para a peça usinada. Este pode afetar o correto funcionamento de um componente se a superfície não apresentar as características adequadas para a aplicação. Por esta razão é necessário determinar o grau de rugosidade que as peças devem apresentar. $\mathrm{O}$ acabamento superficial das peças está diretamente relacionado com as condições do processo de fabricação (ABOUELATTA et al, 2001).

As superfícies usinadas apresentam particularidades que são inerentes ao processo de usinagem a que foi submetida, por exemplo: torneamento, fresamento, retificação etc. A superfície, por mais perfeita que pareça, apresenta um conjunto de irregularidades. A norma DIN 476, apresenta estes desvios classificados em seis grupos:

- Erros de $\mathbf{1}^{\text {a }}$ ordem - também conhecidos com erros macro-geométricos, são os erros de forma relacionados com a variação e tamanho da peça, ou seja, paralelismo entre superfícies, planicidade de superfície, conicidade, circularidade e cilindricidade. Estes 
erros podem ser medidos por instrumentos convencionais como micrômetros, comparadores, projetores de perfil etc;

- Erros de $2^{\mathrm{a}}$ e $3^{\mathrm{a}}$ ordem são os menores e considerados como micro-geométricos, correspondem respectivamente as ondulações e rugosidade da superfície;

- Erros de $4^{\mathrm{a}}$ ordem são caracterizados por descontinuidades da superficie, são conhecidos por crateras, estrias ou escamas;

- Erros de $5^{\mathbf{a}}$ e $\mathbf{6}^{\mathbf{a}}$ ordens correspondem a estrutura do material onde ocorre alteração da superfície por ação química, como decapagem ( $5^{\mathrm{a}}$ ordem), ou processos físicos e químicos da estrutura da matéria, tais como tensões e deslizamentos da estrutura reticular do material (6 $6^{\mathrm{a}}$ ordem) (CAMARGO, 2005).

\subsection{1- Planicidade}

Para definir um plano são necessários três pontos não colineares ou um ponto e uma reta. Por esta definição, pode-se entender que um plano não possui espessura e, por isto, não possui vales nem picos. No entanto, a fabricação de superfícies ideais em usinagem é extremamente difícil, quando a usinagem é realizada em produção seriada isto se torna improvável. Devido esta dificuldade, são especificadas tolerâncias para determinar o quanto a planicidade está próxima do ideal e quantos dos pontos ou região estão fora dos limites especificados (MAGALHÃES, 2006).

De acordo com a ABNT, o campo de tolerância para planicidade é determinado de modo que a superfície medida esteja entre dois planos paralelos, a uma distancia "t", ou seja, para que uma superfície seja considerada dentro da tolerância determinada, esta necessita estar com todos os pontos dentro do espaço delimitado pelos planos paralelos, conforme ilustração abaixo. 


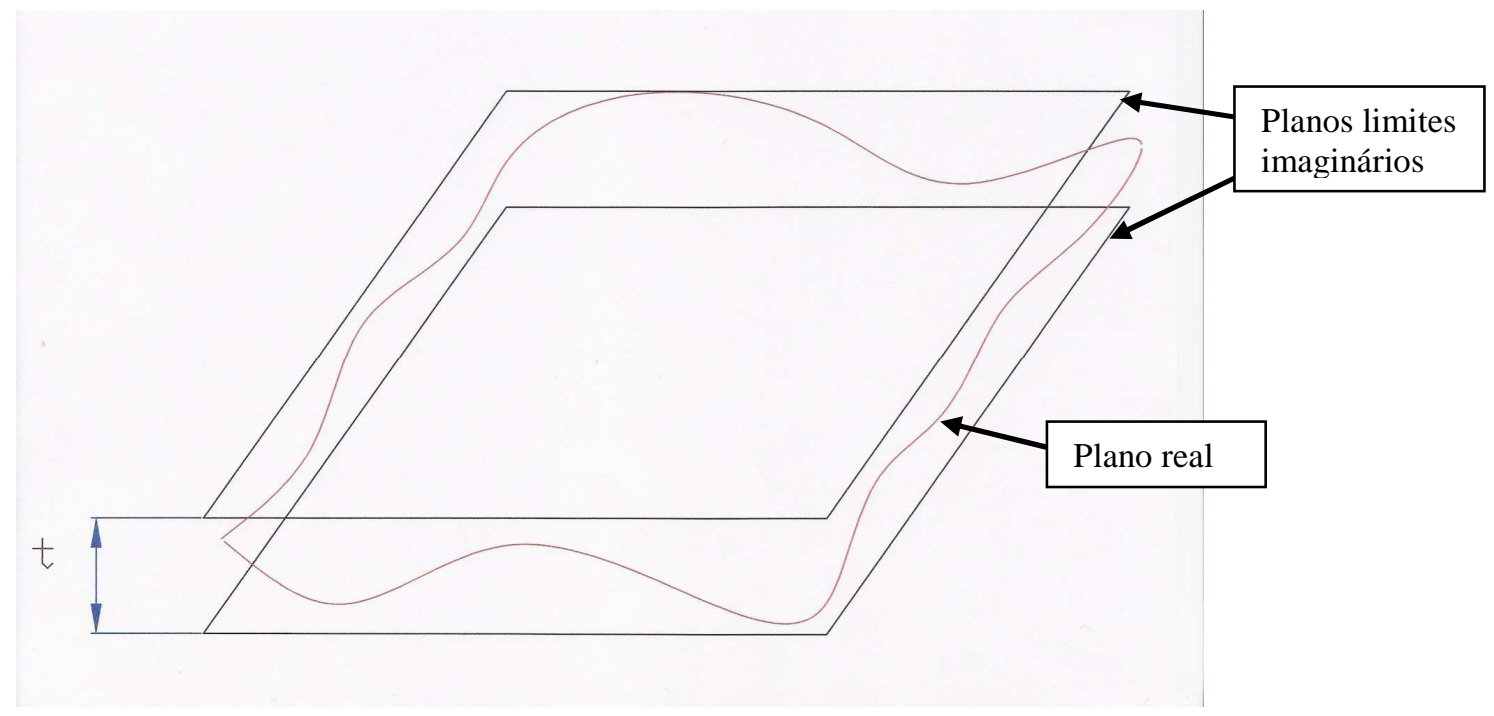

Figura 2.4 - Tolerância de planicidade.

Com a necessidade de fabricação de superfícies com planicidades cada vez mais próximas do ideal, além do desenvolvimento de máquinas e ferramentas com maior qualidade, seguiu-se a necessidade de se evidenciar e mensurar tais superfícies. Os sistemas de medição então evoluíram de mecanismos mecânicos para sistemas computacionais, muitos deles dotados de feixes de laser que, através da reflexão, são capazes de determinar a superfície da peça analisada. (MAGALHÃES, 2006).

Em peças usinadas, os desvios de planicidade mais comuns são a concavidade e a convexidade. No processo de usinagem podem ser encontrados alguns fatores que apresentam grande potencial para determinar erros de planicidade de superfícies (GUIMARÃES, 1999), tais como:

variação da dureza do material ao longo do plano de usinagem;

$>$ desgaste da ferramenta;

$>$ deficiências de fixação;

imperfeições da máquina operatriz;

tensões internas do material. 


\subsection{2- Rugosidade}

A rugosidade de superfícies usinadas é formada por sulcos ou marcas geradas pela ação das ferramentas de corte ou abrasão. Estes sinais de usinagem se encontram superpostos ao conjunto das irregularidades da superficie repetidas em ondas, que são conhecidas como ondulação e podem ser geradas por deficiências da máquina (as vibrações podem gerar ondulação na superfície).

Para a medição da rugosidade, normalmente é utilizado o parâmetro Ra, normalizado pela NBR 6405:1988. A rugosidade Ra é obtida por um cálculo aritmético, em que a relação dos valores absolutos dos afastamentos dos pontos do perfil de rugosidade e a linha média das áreas dos picos e vales da superfície medida é que determinam o valor de Ra (CAMARGO, 2005). A Figura 2.5 ilustra a forma como a rugosidade e a ondulação estão sobrepostas.

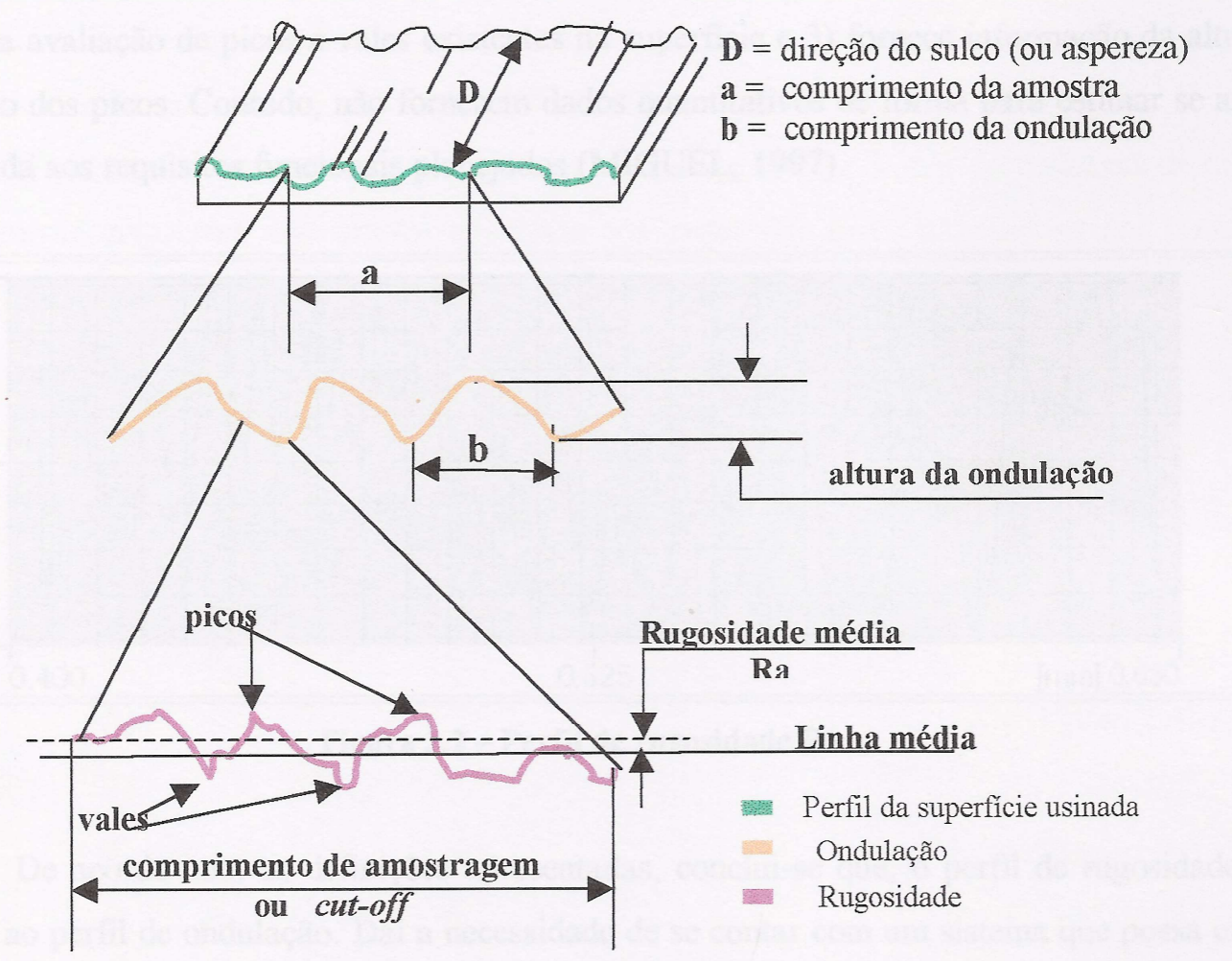

Figura 2.5 - Representação da rugosidade superficial (CAMARGO, 2005 apud BUSCH,1989). 
Rugosidade (Ra)

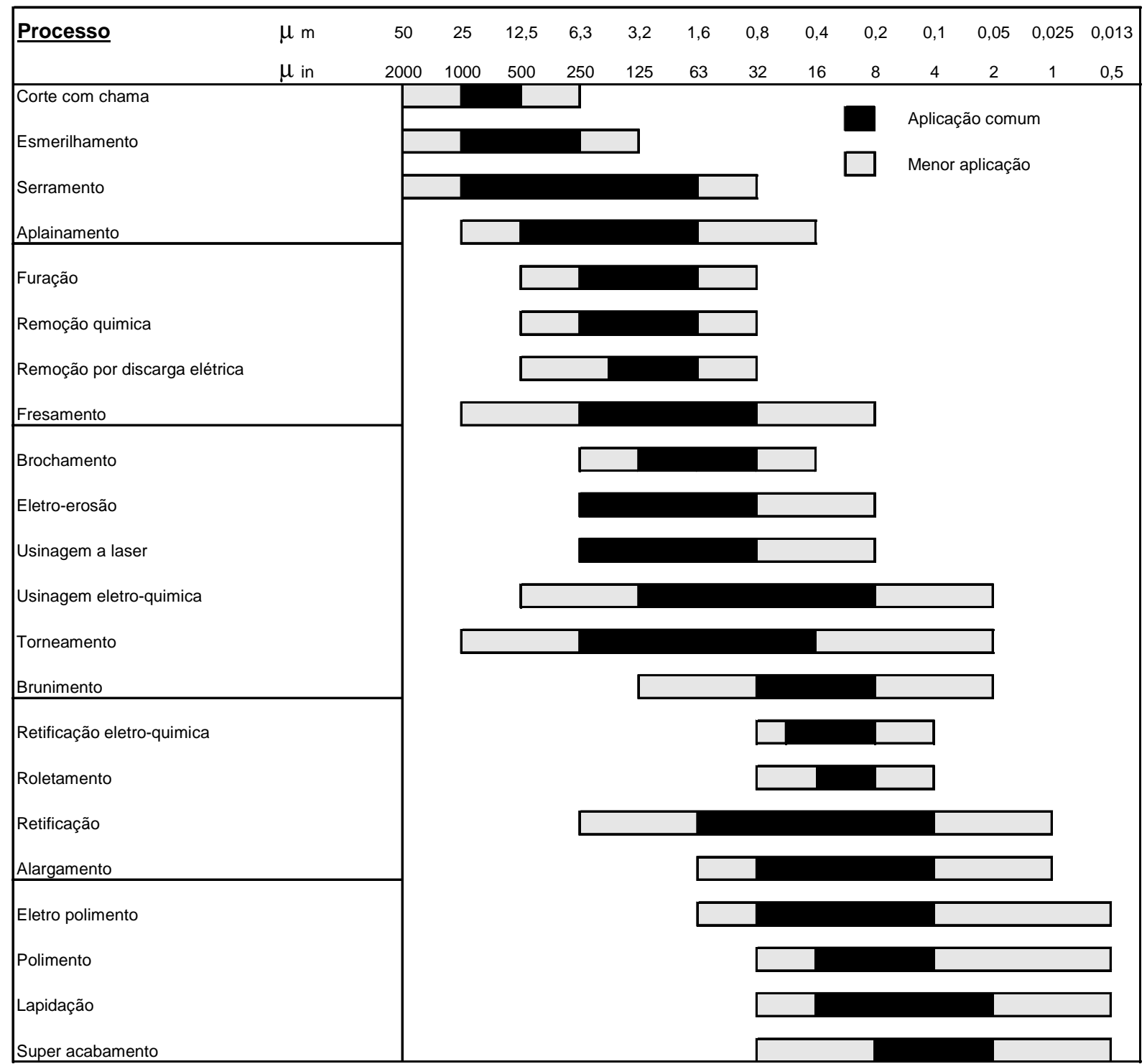

Os diversos processos de usinagem apresentam diferenças de acabamento superficial, sendo que isto ocorre em função da forma como o cavaco é removido. Rugosidades mais baixas são obtidas por processos de acabamento, entretanto, dentro do mesmo processo podem ser determinados diferentes acabamentos em função dos parâmetros de usinagem e do material usinado. Isto permite que um processo de desbaste eventualmente possa atingir adrões elevados de acabamento. A Figura 2.6 mostra níveis diferentes de rugosidade Ra que odem ser obtidos com a variação dos processos. Figura 2.6 - Faixas de valores de rugosidade em função de diferentes processos de usinagem (KALPAKJIAN, 2001).

\subsection{3- Métodos para medição de acabamentos superficiais (rugosidade)}

Existem várias formas de medição de superfícies, estas formas podem ser divididas em três categorias (SODHI et al, 1996):

$>$ método baseado em comparação - as peças são comparadas entre si e o propósito é manter o processo de usinagem sempre com as mesmas características. 
Trata-se de um método pouco preciso, uma vez que o senso tátil e visual determinam a comparação e aprovação das peças;

método de medição direta - neste método as peças são medidas através do contato físico da superfície da peça com aparelhos que calculam o grau do acabamento superficial. Este método apresenta a possibilidade de danificar a peça devido o contato com o aparelho. Este é o método mais utilizado em indústrias;

método de medição sem contato - este é o método mais preciso para medição de rugosidade, onde utiliza-se aparelhos com leitura óptica ou laser para medição de superfícies. Além da maior confiabilidade da medição, este método apresenta também a vantagem de não danificar a superfície, no entanto é o mais caro e mais lento dos três métodos. 


\section{3- Materiais e Método Experimental}

\section{1- Material para experimentação}

A peça em estudo é um bloco de ferro fundido cinzento, utilizado na fabricação de compressores herméticos em que, para a separação das câmaras de sucção e compressão, é necessário que a peça tenha um canal paralelo para alojar e permitir a movimentação de uma palheta. Em virtude desta necessidade, utilizou-se o processo de brochamento para fazer um canal no corpo do bloco. A representação está na Figura 3.1 juntamente com o dimensional.

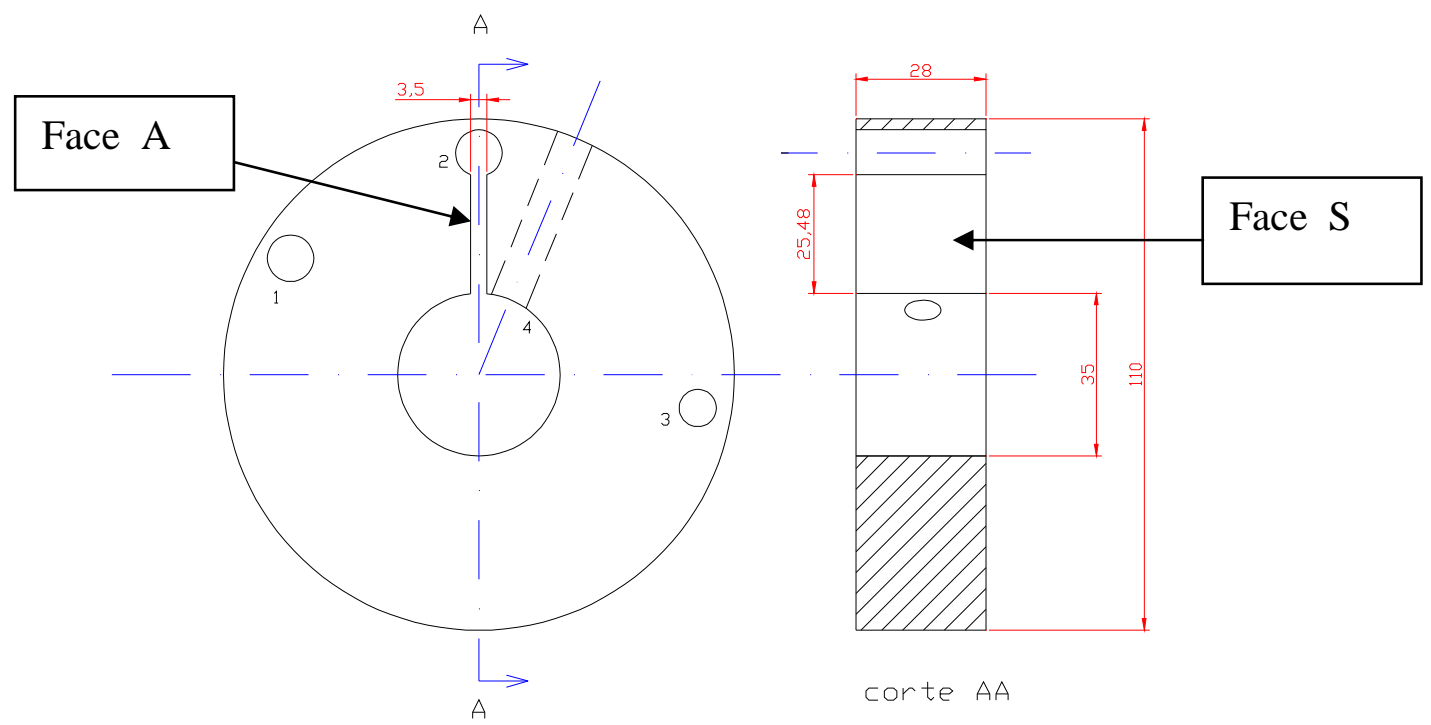

Figura 3.1 - Croqui do bloco.

De acordo com a Figura 3.1, observa-se o bloco com geometria cilíndrica, onde os diâmetros interno e externo são torneados e concêntricos e as faces são retificadas e paralelas entre si. As furações axiais 1 e 3 são necessárias para a fixação e posicionamento da peça no dispositivo da brochadeira. A furação axial 2 é importante para a passagem livre da brocha na parte frontal da mesma, já que o corte e o alisamento é feito pelas laterais das ferramentas. A 
furação radial 4 é a entrada do gás para a câmara de compressão e fica próxima a uma das paredes do canal.

As peças utilizadas no estudo já apresentavam um canal que foi usinado em um brochamento de desbaste. Esta operação de preparação não é o foco do trabalho e esta usinagem não foi analisada, porém a geometria e as dimensões deste canal foram medidas e utilizadas no estudo. As peças foram posteriormente submetidas ao brochamento em acabamento, onde foram realizados os testes com os parâmetros de usinagem e coletados os dados sobre as características da peça brochada.

Para este experimento foram utilizados blocos em ferro fundido cinzento; o bloco tem geometria cilíndrica com os diâmetros torneados (interno com 35 mm e externo com $110 \mathrm{~mm}$ ) e as faces retificadas (altura de $28 \mathrm{~mm}$ ).

Na Figura 3.2 tem-se o bloco e a parte do bloco que foi cortado para realizar a medição da planicidade.

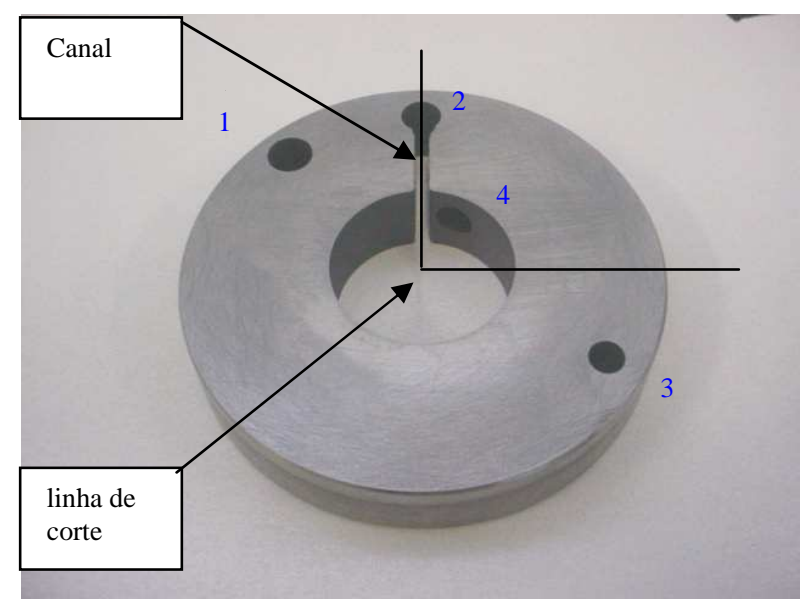

(a) Visão geral do bloco

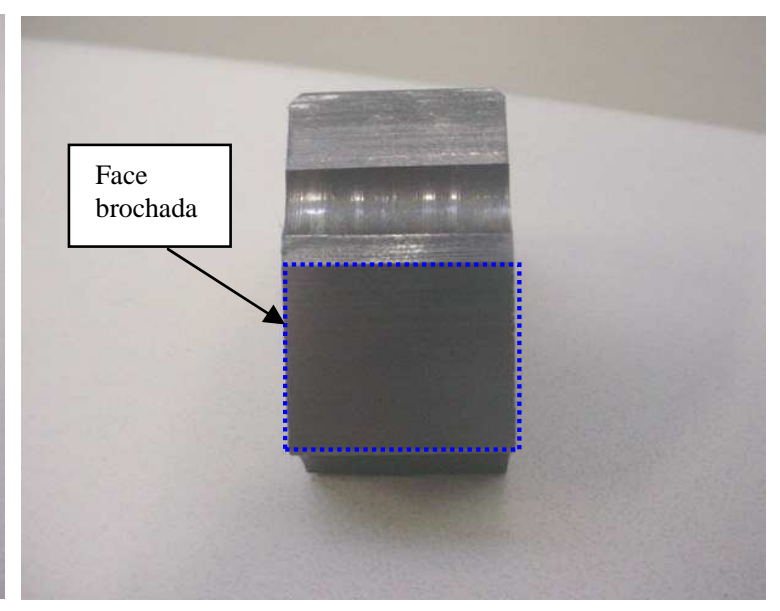

(b) Bloco cortado mostrando a face do canal

Figura 3.2 - Aspecto geral do bloco estudado

Na Figura 3.2(a) tem-se o bloco com três furos axiais, dois necessários para o posicionamento da peça no dispositivo da brochadeira (1 e 3) e o furo 2 como alívio para a 
passagem das ferramentas de brochamento. Observa-se também o canal brochado em acabamento que tem a largura de 3,500 mm e faz a ligação do diâmetro do diâmetro interno do bloco até o furo 2. Vê-se ainda a saída de um furo radial (4) com $8 \mathrm{~mm}$ de diâmetro próximo a face da direita do canal. Este furo deixa uma parede delgada entre o próprio furo e o canal.

\section{2- Máquina-ferramenta}

A usinagem de acabamento foi realizada em uma brochadeira vertical Apex. Este equipamento tem cabeçote duplo para usinagem simultânea de duas peças, no entanto, utilizou-se apenas um dos dispositivos para evitar a introdução da variável "cabeçote".

A máquina tem o eixo de movimentação do ferramental no sentido vertical, com os movimentos de avanço e retorno do carro porta-ferramentas controlados por um motor de passo, este fica instalado em um fuso de esferas que garante um ciclo constante e o controle das velocidades. Para o teste trabalhou-se com a velocidade em $2 \mathrm{~m} / \mathrm{min}$ e $6 \mathrm{~m} / \mathrm{min}$.

O dispositivo porta-peça é dotado de cinco pinos de apoio com as faces retificadas, de forma que, quando a peça é colocada sobre os pinos, estes determinam o referenciamento da peça pela face de apoio e em posição normal à direção do movimento da ferramenta. Para garantir que a peça não se mova durante a usinagem, o sistema hidráulico movimenta uma garra que prende a peça com pressão de $15 \mathrm{MPa}$, pressão esta suficiente para garantir a fixação e o travamento da peça no dispositivo. O ferramental é refrigerado com óleo solúvel da Castrol concentrado em $20 \%$ e o fluxo do óleo fica direcionado para a região de corte por mangueira flexível com vazão de 5 1/min e pressão de $0,15 \mathrm{MPa}$. 


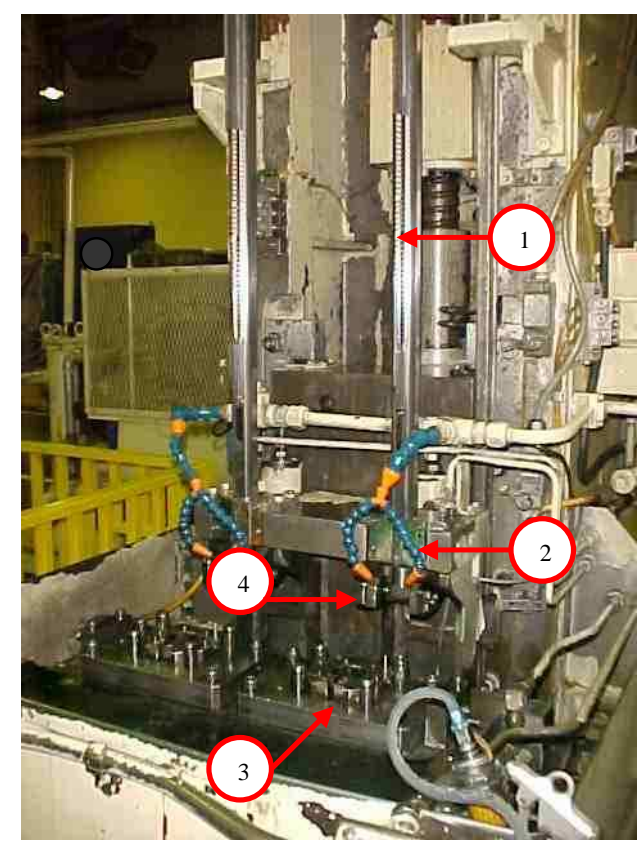

Descrição de componentes da brochadeira:

1- magazine com as ferramentas

2- mangueiras de refrigeração

3- dispositivo porta-peça

4- garra de fixação

Figura 3.3 - Brochadeira Apex.

\section{3- Ferramentas de brochar}

O magazine porta ferramentas é uma barra cilíndrica de aço ABNT M2, que tem como características mecânicas a alta dureza aliada a grande tenacidade e resistência à abrasão; tem comprimento de 2,5 metros e diâmetro de $34 \mathrm{~mm}$. Possui alojamento para a inserção dos segmentos de ferramentas e furações para a fixação das mesmas. Cada uma das ferramentas é fixada por quatro parafusos Allen que são presos pela parte posterior do magazine porta ferramentas. Lateralmente as ferramentas são travadas por outros três parafusos-estojo que garantem o alinhamento das ferramentas com relação à linha de centro do magazine.

Para este trabalho, o magazine foi montado com duas ferramentas de corte com as arestas laterais em ambos os lados, posteriormente a este processo foram montadas duas ferramentas diamantadas, ambas com cortes laterais. As Figuras 3.4 e 3.5 mostram as ferramentas citadas. 


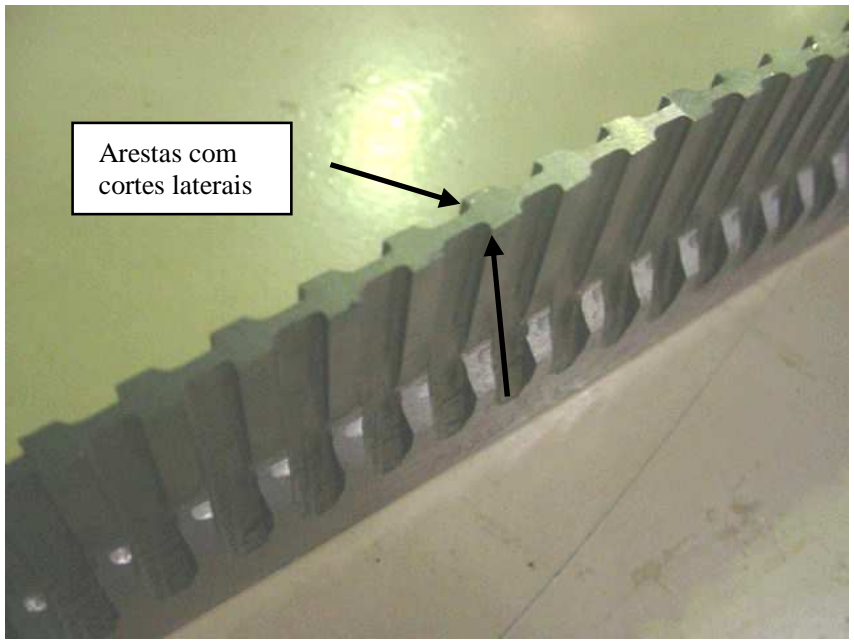

Figura 3.4 - Ferramenta de corte

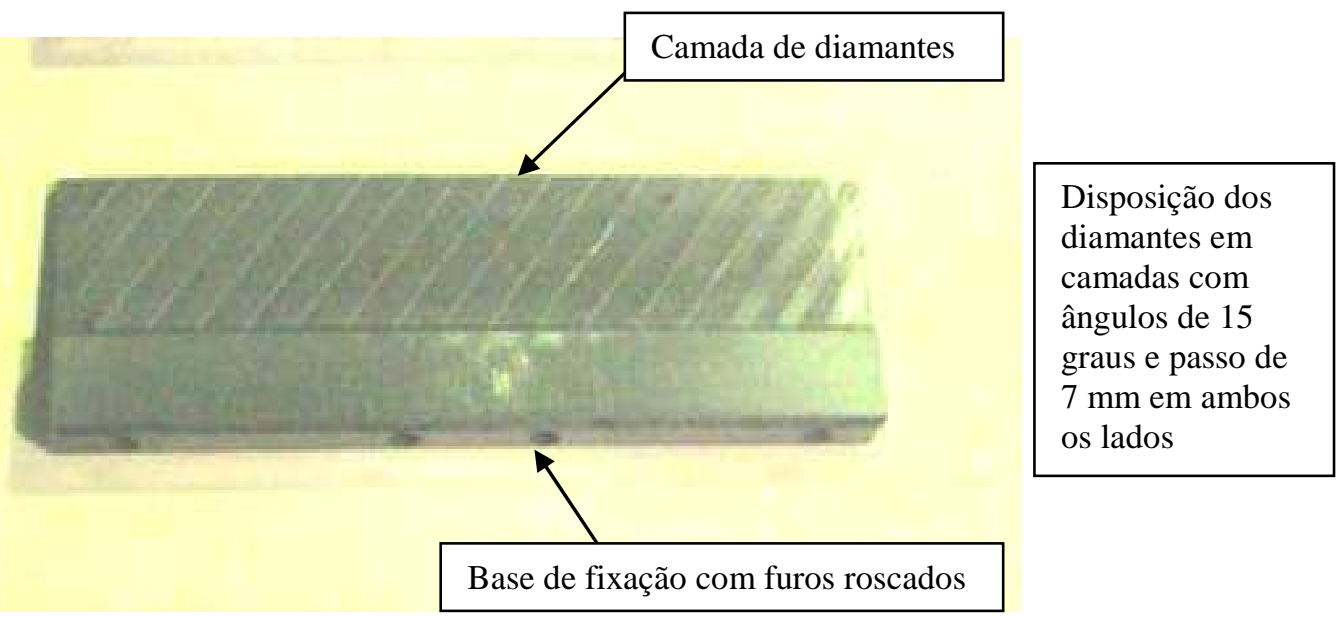

Figura 3.5 - Ferramenta diamantada

Conforme Figura 3.4, a ferramenta de corte tem os dentes laterais com as arestas de corte dispostas simetricamente em ambos os lados, de forma que, quando a ferramenta entra na peça, os dois lados da ferramenta removem material no mesmo plano de referência. Esta construção permite que as forças de corte equilibrem a ferramenta dento do canal brochado, e conseqüentemente, a remoção do material também é proporcional em ambas as faces do canal.

Na parte anterior do magazine foi montado um conjunto de duas ferramentas de corte, sendo que estas ferramentas eliminam os riscos das ferramentas nas faces do canal previamente aberto em desbaste. A primeira ferramenta de acabamento foi construída com 19 
dentes e com ângulo de inclinação de $10^{\circ}$. A remoção do material é feita lateralmente, mas a progressão se dá no sentido radial em virtude do ângulo de cunha da ferramenta. A partir do $14^{\circ}$ dente o ângulo de cunha termina e os dentes se apresentam com o comprimento total (27 mm). É importante frisar que estes últimos dentes têm filetes de $0,3 \mathrm{~mm}$.

A segunda ferramenta de corte não tem o ângulo de cunha e apresenta 20 dentes, sendo todos com o comprimento total. Os seis primeiros dentes apresentam inclinação de $10^{\circ}$ com incrementos de $0,01 \mathrm{~mm}$ e os 14 dentes restantes não têm ângulo de inclinação e nem incrementos de altura. Todos os dentes desta ferramenta apresentam filetes de 0,3 mm.

As duas ferramentas de corte são construídas em aço ABNT M2 com tratamento térmico (dureza 64-66 HRC). Os dentes laterais são dispostos em passos de 7,14 mm, sendo que todos os dentes apresentam ângulo de folga de $45^{\circ}$ e ângulo de saída de $6^{\circ}$. A câmara de cavaco tem capacidade para alojar o material removido.

Após as ferramentas de corte que normalizam as faces do canal previamente aberto em desbaste, foram montadas duas ferramentas diamantadas que juntas, removem aproximadamente $15 \mu \mathrm{m}$ de cada face do canal brochado.

Posteriormente às ferramentas diamantadas, montou-se um conjunto de 26 roletes para compactar as superfícies usinadas, onde esta ferramenta também tem a função alisadora. Este conjunto de ferramentas de acabamento montadas na disposição descrita tem o propósito de gerar uma superfície com melhor planicidade e rugosidade mais baixa.

A máquina possui um sistema de micros fim de curso que informam ao CLP o momento em que a ferramenta diamantada atingiu a posição de usinagem. Através deste recurso é possível controlar o número de vezes que esta ferramenta passa pelo canal (movimentos de subida e descida), permitindo desta maneira determinar a espessura do canal e melhorar a planicidade das faces. 


\section{4- Método experimental}

A usinagem das peças foi realizada segundo a metodologia de análise fatorial completa e as variáveis estudadas no experimento foram:

$\checkmark$ Velocidade de corte;

$\checkmark$ Sobremetal;

$\checkmark \quad$ Número de passadas;

$\checkmark$ Combinação de ferramentas diamantadas.

A partir da matriz foram feitas cinco peças para cada combinação, ou seja, cinco réplicas que resultaram em 80 peças para análise. As características medidas foram:

$\checkmark$ Conicidade vertical, que é o erro de paralelo das faces no sentido axial;

$\checkmark$ Conicidade horizontal, que é o erro de paralelo das faces no sentido radial;

$\checkmark$ Espessura (para análise de sobremetal);

$\checkmark$ Perpendicularismo do canal;

$\checkmark$ Planicidade;

$\checkmark \quad$ Rugosidade das superfícies.

Para a medição da geometria das peças utilizou-se calibrador Marposs especial para esta aplicação. Este aparelho foi construído com um conjunto de sensores capazes de realizar leituras com precisão de $0,1 \mu \mathrm{m}$ e foi programado para medir espessura, conicidade vertical e conicidade horizontal e perpendicularismo do canal, bem como os valores resultantes das medições são apresentados em um monitor acoplado à base do aparelho. A Figura 3.6 representa o aparelho utilizado. 


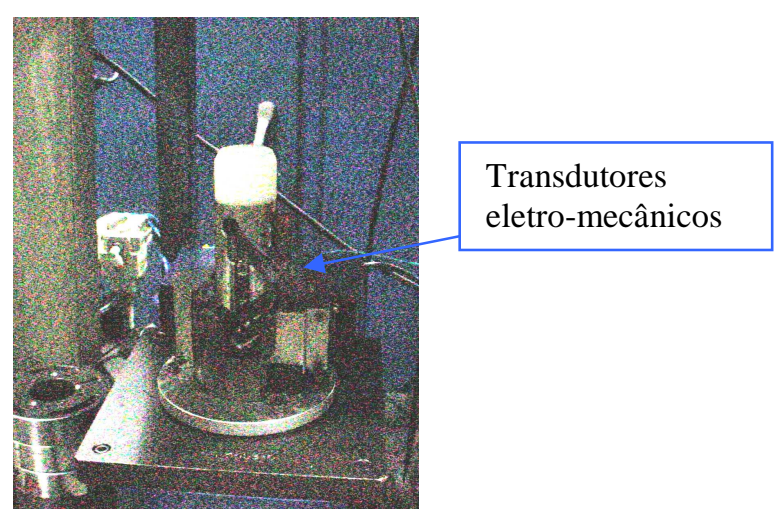

(a): Base de medição das características geométricas do canal de faces paralelas

Figura 3.6 - Sistema de medição das características geométricas.

A medição da planicidade das faces foi realizada num aparelho de leitura óptica modelo Tropel Flat Master 200 de fabricação Coning. O leitor óptico do aparelho tem resolução de $0,01 \mu \mathrm{m}$ e através da diferença de alturas entre os pontos da superfície da peça, o programa computacional gera a superfície e aponta os valores encontrados da leitura. A representação este aparelho está na Figura 3.7.

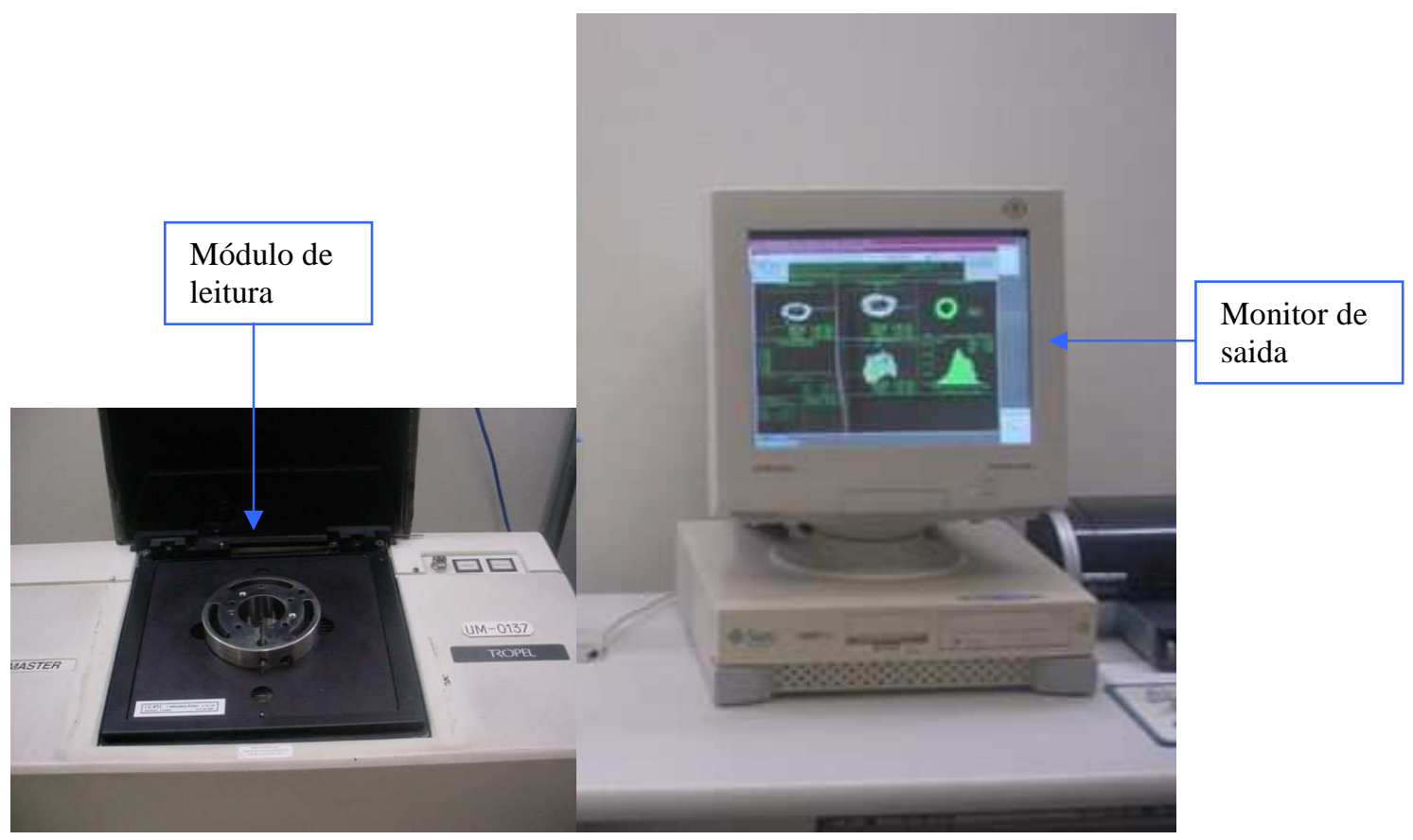

Figura 3.7 - Aparelho Tropel Flat Master 200. 
A Figura 3.8 mostra um exemplo da medição da planicidade de uma superfície neste aparelho.

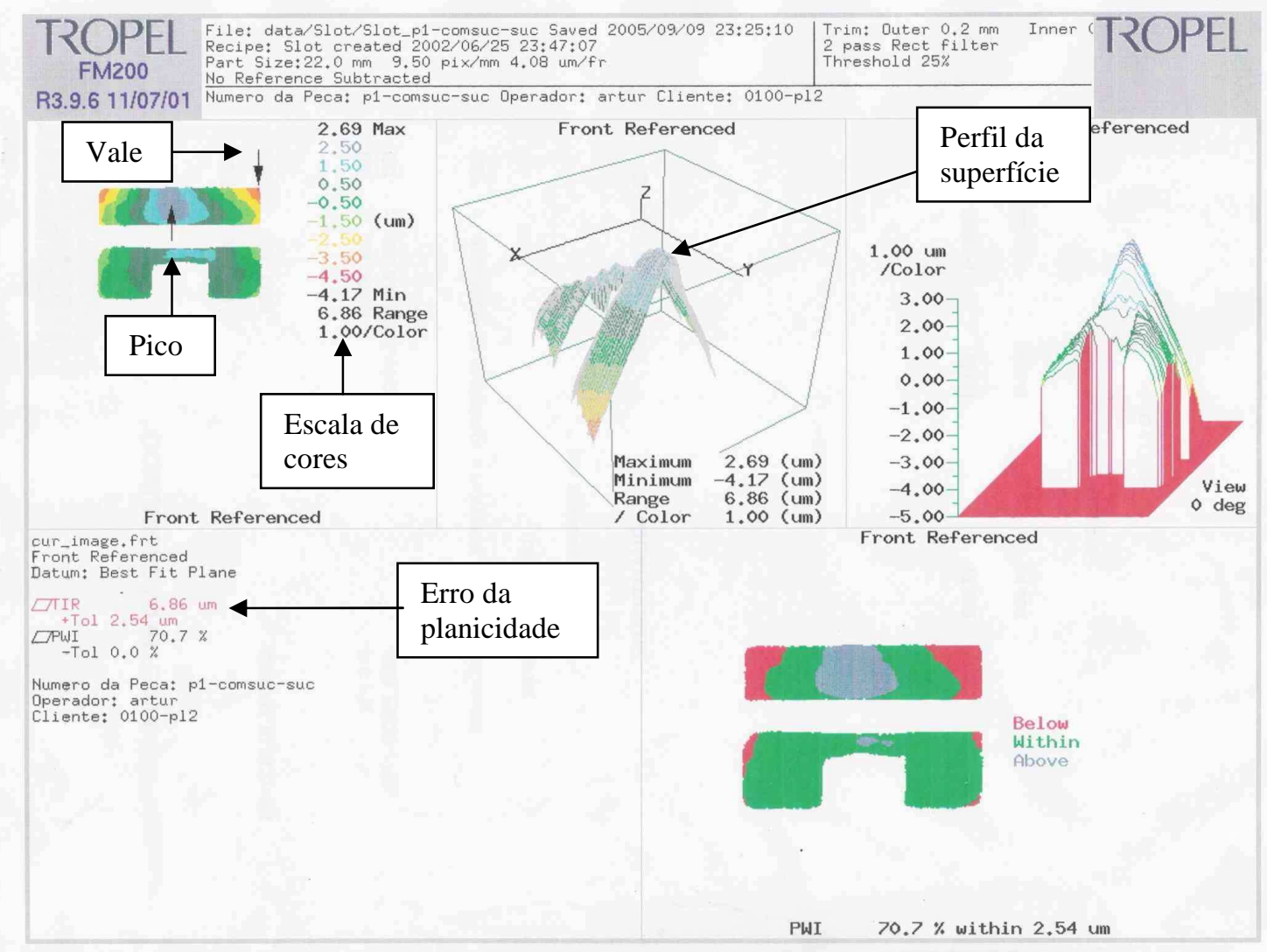

Figura 3.8 - Representação da planicidade de uma peça medida no Tropel.

A medição é realizada através da diferença de altura dos pontos da face da peça que está apoiada sobre o aparelho, sendo que a partir desta leitura é gerado o gráfico conforme figura 3.8, onde encontramos as seguintes informações:

$>\quad$ Os valores em mícrons da escala de cores são os valores das alturas encontradas entre os pontos da superfície da peça que foi varrida pelo leitor óptico;

$>\quad$ O intervalo mostra a maior diferença medida entre os pontos que é o valor do erro de planicidade da superfície;

Os gráficos são coloridos conforme a escala e os pontos mais altos (região roxa) e mais baixos (região vermelha) estão indicados pelas setas. 
A rugosidade foi medida em rugosímetro Taylor utilizando cut off de 0.1 " e medições em Ra e Rt para um Lc=0,01 $\mu$ inch e os valores foram colhidos em 3 pontos diferentes de ambas as faces do canal brochado.

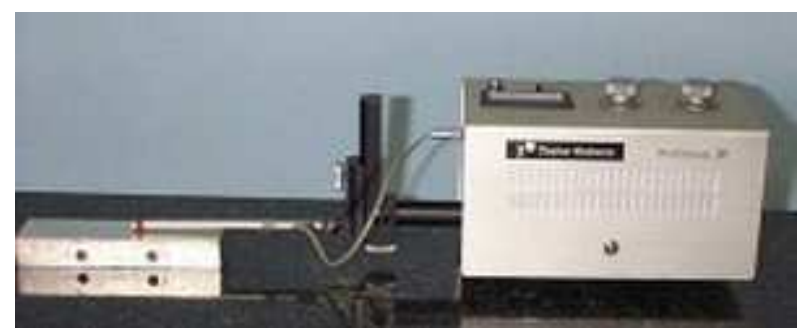

Figura 3.9 - Rugosímetro Taylor Robson.

Mediu-se também a espessura da parede da face na posição mais crítica em que se encontra uma furação radial muito próxima à superfície brochada e que influencia na planicidade desta face. Para esta medição utilizou-se paquímetro com tolerância de $0.01 \mathrm{~mm}$.

Todas as peças foram devidamente limpas antes de todas as medições. Primeiramente foram medidas as características geométricas do canal e posteriormente as peças foram cortadas para que pudessem ser realizadas as medições de rugosidade e planicidade.

As variáveis estudadas no experimento foram 4 (quatro) com 2 (dois) níveis para cada variável (fator):

$\checkmark$ Velocidade de corte;

$\checkmark$ Sobremetal;

$\checkmark \quad$ Número de passadas;

$\checkmark$ Combinação de ferramentas diamantadas.

Os níveis foram determinados segundo informações já conhecidas como prováveis limites, capacidade do equipamento e tolerâncias admissíveis para o processo. São elas:

1) Velocidade de corte, com os níveis $6 \mathrm{~m} / \mathrm{min}$ e $2 \mathrm{~m} / \mathrm{mim}$;

2) Sobremetal da operação anterior (brochamento para abrir o canal em desbaste), condições de máximo e mínimo material; 
3) Numero de passadas: 6 (seis) e 2 (dois) passes;

4) Combinação de ferramentas diamantadas: foram utilizadas combinações de duas ferramentas de desbaste e duas ferramentas de acabamento, em que somente o tamanho dos grãos difere entre as ferramentas;

Tabela 3.1 - Variáveis do estudo.

\begin{tabular}{|c|c|c|}
\hline \multirow{2}{*}{ V1 } & \multirow{2}{*}{$\mathrm{N}^{\mathrm{o}}$ de passadas } & 6 \\
\hline & & 2 \\
\hline \multirow{2}{*}{$\mathrm{V} 2$} & \multirow{2}{*}{ Ferramentas diamantadas } & $\mathrm{D}+\mathrm{D}$ \\
\hline & & $\mathrm{A}+\mathrm{A}$ \\
\hline \multirow[b]{2}{*}{ V3 } & \multirow{2}{*}{ Velocidade } & $6 \mathrm{~m} / \mathrm{min}$ \\
\hline & & $2 \mathrm{~m} / \mathrm{mim}$ \\
\hline \multirow{2}{*}{ V4 } & \multirow{2}{*}{ Sobremetal } & $0,2665 \mathrm{~mm}$ \\
\hline & & $0,2517 \mathrm{~mm}$ \\
\hline
\end{tabular}

Para tratamento dos dados foi utilizada a metodologia ANOVA e, através desta, foi possível determinar estatisticamente, qual a influência das quatro variáveis e suas combinações nos resultados das características geométricas e superficiais das faces do canal. A partir da matriz de arranjo fatorial foram feitas cinco peças (réplicas) para cada combinação. Os resultados obtidos com as cinco réplicas foram lançados no Minitab. 


\section{4- Resultados}

Os resultados obtidos com o experimento foram analisados separadamente. Para cada característica verificou-se quais dos fatores foram significantes para o resultado e em seguida foram feitas análises dos resíduos para comprovar a validação dos dados. Os fatores foram comparados entre si para determinar o grau de interferência no processo e, após a análise individual os fatores foram combinados para verificar as relações que interferem no resultado.

\section{$\underline{4.1-\text { Resultados referentes à Rugosidade Ra da superfície do canal }}$}

Foi utilizada a ANOVA para determinar o grau de significância das variáveis independente de suas possíveis combinações.

ANOVA para Rugosidade Ra em função de: Velocidade, Passes, Ferramenta Diamantada e Sobremetal.

Tabela 4.1 - Análise ANOVA da Rugosidade Ra com os fatores analisados individualmente.

\begin{tabular}{|l|c|c|c|}
\hline Fator & Tipo & Níveis & Valores \\
\hline Veloc. & Fixo & 2 & $2 ; 6$ \\
\hline Passes & Fixo & 2 & $2 ; 6$ \\
\hline Ferram. Diamantada & Fixo & 2 & Desbaste; Acabamento \\
\hline Sobremetal & Fixo & 2 & min; max \\
\hline
\end{tabular}

\begin{tabular}{|l|c|c|c|c|c|}
\hline Fator de controle & $\begin{array}{c}\text { Grau de } \\
\text { liberdade }\end{array}$ & $\begin{array}{c}\text { Soma dos } \\
\text { quadrados }\end{array}$ & $\begin{array}{c}\text { Quadrado } \\
\text { médio }\end{array}$ & Teste F & Valor P \\
\hline Veloc. & 1 & 6,1 & 6,1 & 0,01 & 0,906 \\
\hline Passes & 1 & 1312,2 & 1312,2 & 3,07 & 0,084 \\
\hline Ferram. Diamantada & 1 & 11472,0 & 11472,0 & 26,81 & 0,000 \\
\hline Sobremetal & 1 & 2668,1 & 2668,1 & 6,24 & 0,015 \\
\hline Erro & 75 & 32091,6 & 427,9 & & \\
\hline Total & 79 & 47550,0 & & & \\
\hline
\end{tabular}

Verificando a coluna P na Tabela 3, tem-se que os fatores Ferramenta Diamantada e Sobremetal são significantes para o intervalo de confiança de 95\%, onde esta consideração pode ser feita quando o $\mathrm{P}_{\text {_valor }}$ for menor que 0,050 . Portanto estes fatores interferem no 
resultado da Rugosidade Ra da superfície do canal. Com os fatores Velocidade e Passes, onde o P_valor é maior que 0,050 , podemos afirmar que estas variáveis não são significativas para a Rugosidade Ra nos níveis em que foram realizados os testes. Para verificar a validação dos dados foram analisados os resíduos. Na Figura 4.1 estão plotados os gráficos de resíduo para análise da normalidade dos dados.

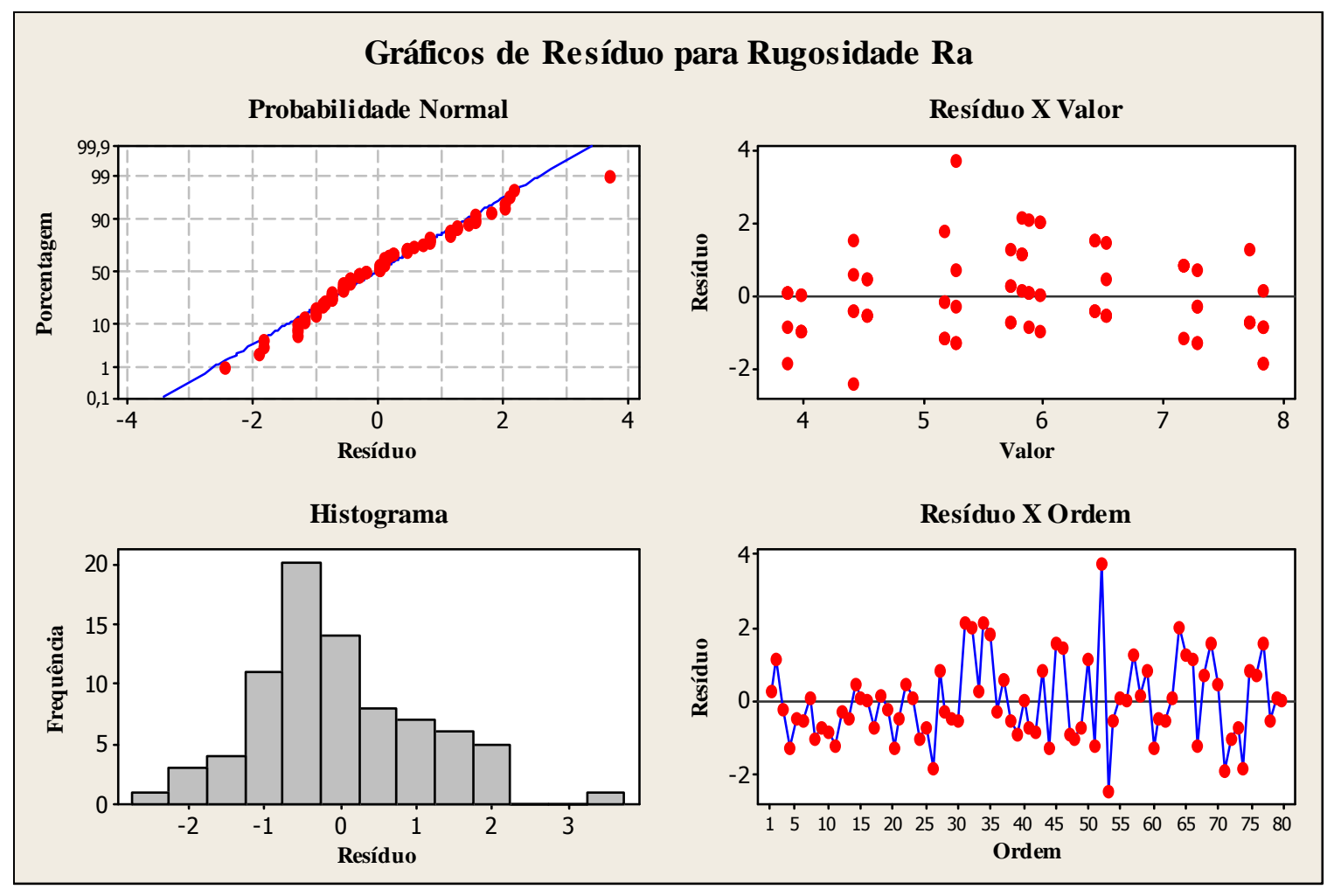

Figura 4.1 - Gráficos de resíduo para Rugosidade Ra.

Na Figura 4.1 observamos que no gráfico de Probabilidade Normal os dados dos resíduos estão sobre a reta normal e no gráfico Histograma a distribuição também está próxima de uma normal, sendo que estes dois gráficos permitem considerar que os dados são normais. O gráfico de Resíduo X Valor apresenta os pontos distribuídos de forma aleatória, mostrando que para os valores analisados o modelo é adequado. O gráfico Resíduo X Ordem apresenta pequena diferença na dispersão, fato que demonstra estabilidade na coleta dos dados e pouca interferência externa na medição das peças ou no material usinado. 
Para a análise individual das variáveis foi utilizado o gráfico de efeitos (Main Effects Plot, metodologia ANOVA através do Minitab). Esta análise é feita considerando a inclinação da reta em relação à linha média dos valores da Rugosidade Ra. Quanto menor a inclinação da reta, menor é a interferência da variável no processo, por exemplo: se alguma das variáveis (Velocidade, Passes, Ferramenta Diamantada ou Sobremetal) apresentarem a reta sobre a linha média, significa que a variação desta não apresenta interferência no resultado da planicidade para o intervalo estudado. Portanto, valores diferentes dos fatores irão determinar os mesmos resultados para a característica analisada. O gráfico da Figura 4.2 representa o efeito individual das variáveis.

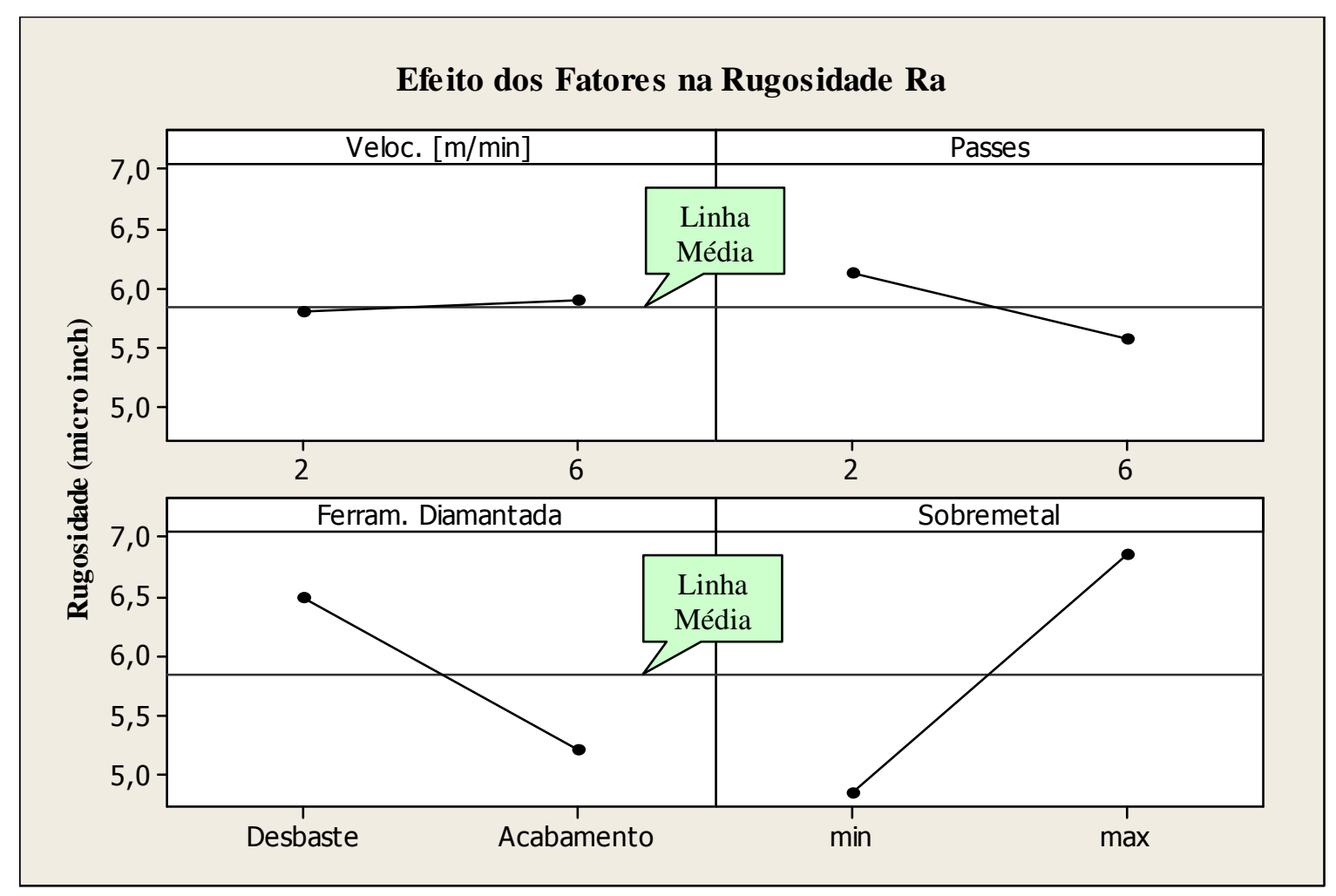

Figura 4.2 - Interferência das Variáveis no Processo para Rugosidade Ra.

Neste caso, podemos observar na Figura 4.2 que o Sobremetal apresenta a maior inclinação da reta em relação à linha média dos valores da Rugosidade Ra, por isto pode-se afirmar que individualmente esta variável apresenta maior interferência no processo se 
comparado com os demais fatores. Para o fator Sobremetal na condição de mínima, o valor da Rugosidade Ra tende a ser menor.

Para analisar a variância de cada um dos quatro fatores do estudo utilizou-se o "OneWay ANOVA“ também do Minitab e os resultados estão registrados na Figura 4.3.

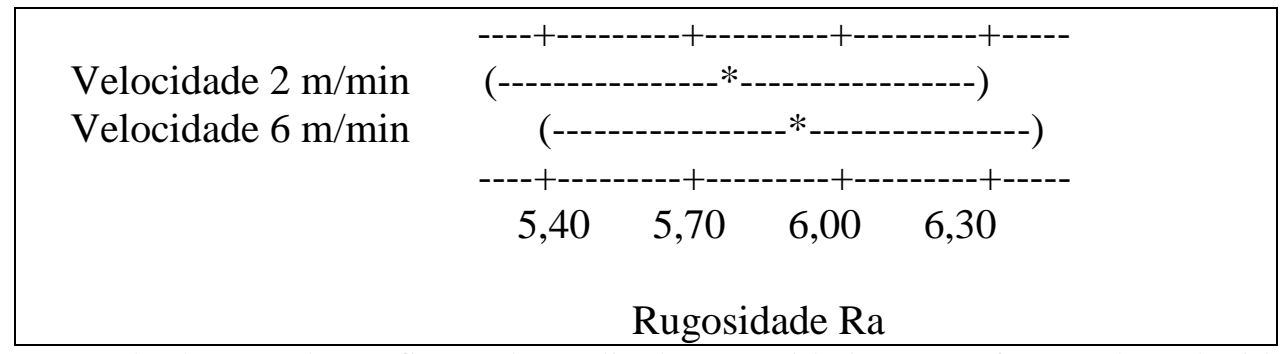

(a): Intervalo de 95\% de confiança da média da Rugosidade Ra em função da Velocidade.

Passes 2

Passes 6

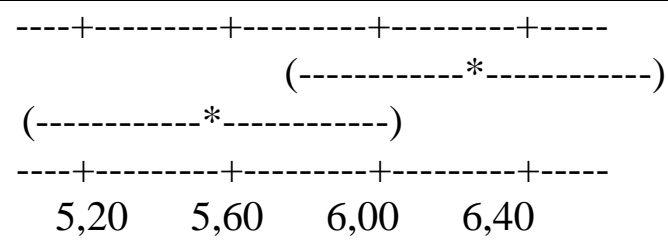

Rugosidade Ra

(b): Intervalo de 95\% de confiança da média da Rugosidade Ra em função dos Passes.

Ferramenta Desbaste Ferramenta Acabamento

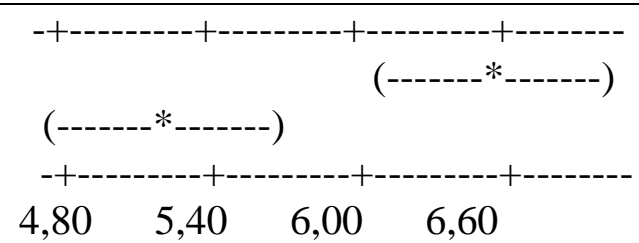

Rugosidade Ra

(c): Intervalo de 95\% de confiança da média da Rugosidade Ra em função da Ferramenta Diamantada.

Sobremetal Mínima Sobremetal Máxima

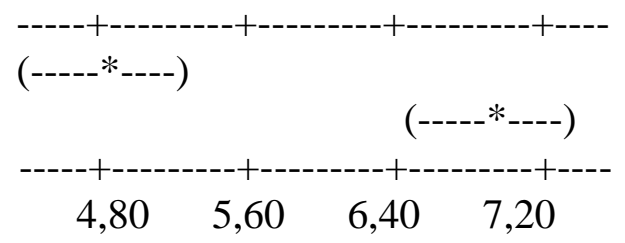

Rugosidade Ra

(d): Intervalo de 95\% de confiança da média da Rugosidade Ra em função do Sobremetal.

Figura 4.3 - Análise do Intervalo de 95\% de confiança para os quatro fatores em ralação à Rugosidade $\mathrm{Ra}$. 
Podemos verificar nas Figuras 4.3(a) e 4.3(b) que, para os fatores Velocidade e Passes nos dois níveis em que foram analisados, os valores da Rugosidade Ra encontrados para cada nível se sobrepõem em relação ao outro nível, sendo que no caso da Velocidade as médias são quase idênticas. Esta sobreposição demonstra que estes fatores são pouco significativos para a Rugosidade Ra, pois os mesmos valores de Rugosidade Ra podem ser encontrados em ambos os níveis.

Para as variáveis Ferramenta Diamantada e Sobremetal, nas Figuras 4.3(c) e 4.3(d), onde os valores de Rugosidade Ra não apresentam valores comuns entre os dois níveis, podese afirmar que individualmente cada uma delas interfere de forma significativa nos valores da Rugosidade Ra.

Com a constatação da normalidade dos dados através dos Gráficos de Resíduo da Figura 4.1, analisou-se a combinação dos fatores para determinar se as combinações destes apresentam alterações na Rugosidade Ra, ou seja, se as interações apresentam significância para o estudo. Através do ANOVA temos os dados das combinações entre os fatores dois a dois, conforme Tabela 4.2.

Tabela 4.2 - Análise ANOVA da Rugosidade Ra com os fatores combinados dois a dois.

\begin{tabular}{|l|c|c|c|c|c|}
\hline Fator de controle & $\begin{array}{c}\text { Grau de } \\
\text { liberdade }\end{array}$ & $\begin{array}{c}\text { Soma dos } \\
\text { quadrados }\end{array}$ & $\begin{array}{c}\text { Quadrado } \\
\text { médio }\end{array}$ & $\begin{array}{c}\text { Teste } \\
\mathrm{F}\end{array}$ & $\begin{array}{c}\text { Valor } \\
\mathrm{P}\end{array}$ \\
\hline Veloc. & 1 & 0,200 & 0,200 & 0,17 & 0,677 \\
\hline Passes & 1 & 6,050 & 6,050 & 5,28 & 0,025 \\
\hline Ferram. Diamantada & 1 & 33,800 & 33,800 & 29,52 & 0,000 \\
\hline Sobremetal & 1 & 80,000 & 80,000 & 69,87 & 0,000 \\
\hline Veloc. *Passes & 1 & 0,050 & 0,050 & 0,04 & 0,835 \\
\hline Veloc. *Ferram. Diamantada & 1 & 0,000 & 0,000 & 0,00 & 1,000 \\
\hline Veloc. *Sobremetal & 1 & 3,200 & 3,200 & 2,79 & 0,099 \\
\hline Passes *Ferram. Diamantada & 1 & 0,050 & 0,050 & 0,04 & 0,835 \\
\hline Passes *Sobremetal & 1 & 4,050 & 4,050 & 3,54 & 0,064 \\
\hline Ferram. Diamantada *Sobremetal & 1 & 9,800 & 9,800 & 8,56 & 0,005 \\
\hline Erro & 69 & 79,000 & 1,145 & & \\
\hline Total & 79 & 216,200 & & & \\
\hline
\end{tabular}


Na coluna $\mathrm{P}$ da Tabela 4.2 podemos identificar que apenas a combinação entre Ferramenta Diamantada e Sobremetal é significante para os resultados da Rugosidade Ra, que é a relação entre dois fatores que apresentaram significâncias quando analisados isoladamente. Para ilustrar estas relações foram plotados os gráficos de Interação dos Fatores dois a dois através do ANOVA e os resultados estão ilustrados na Figura 4.4.

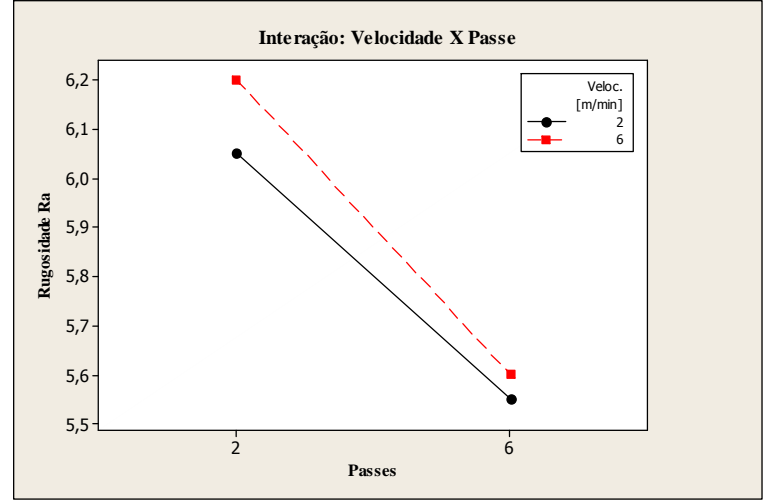

(a) - Velocidade X Passe

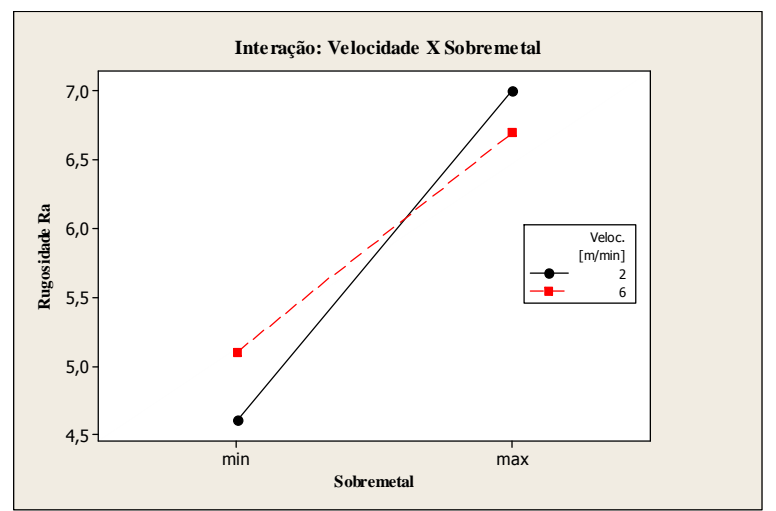

(c) - Velocidade X Sobremetal

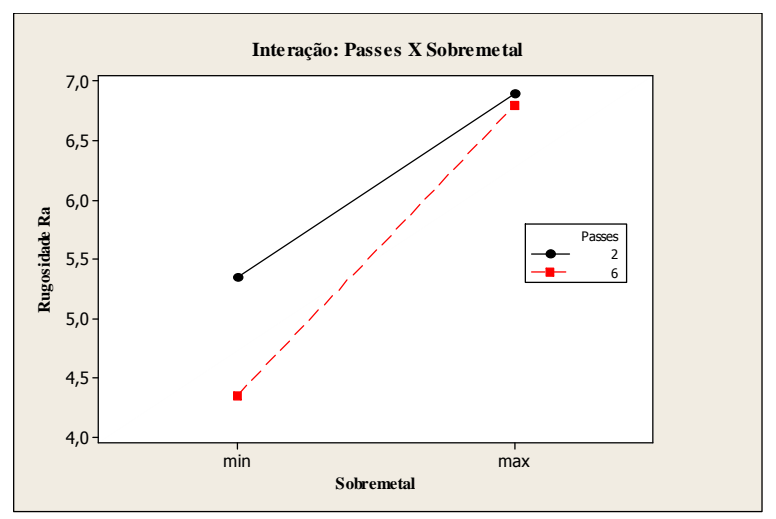

(e): Passe X Sobremetal

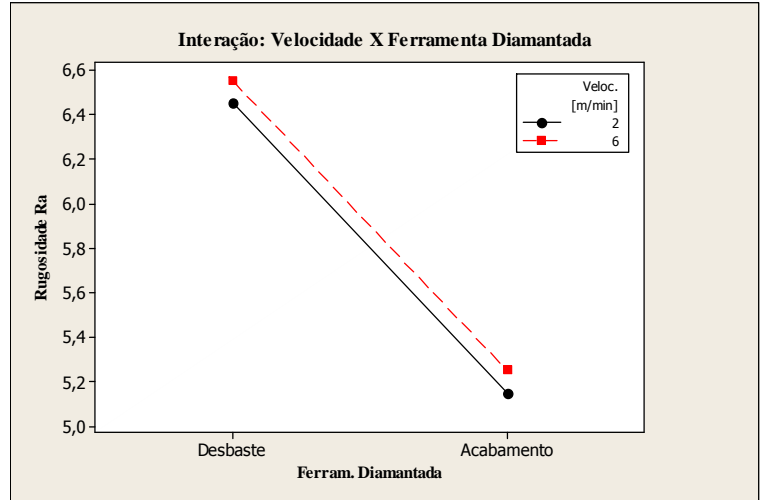

(b) - Velocidade X Ferramenta Diamantada

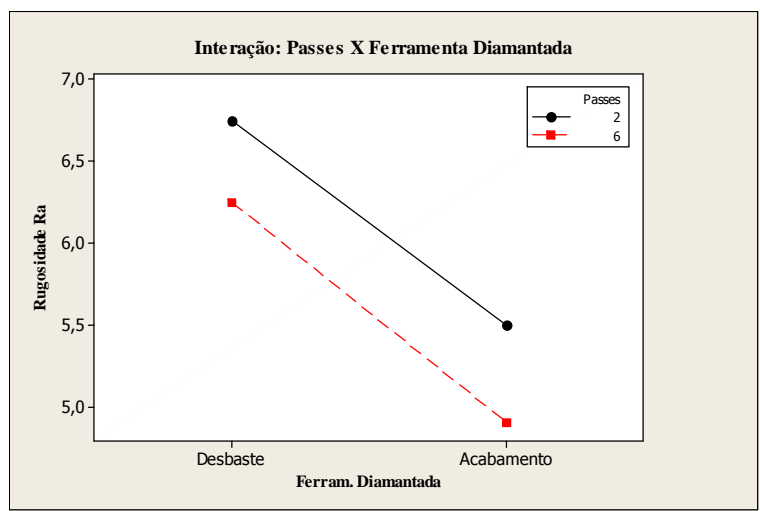

(d) - Passe X Ferramenta Diamantada

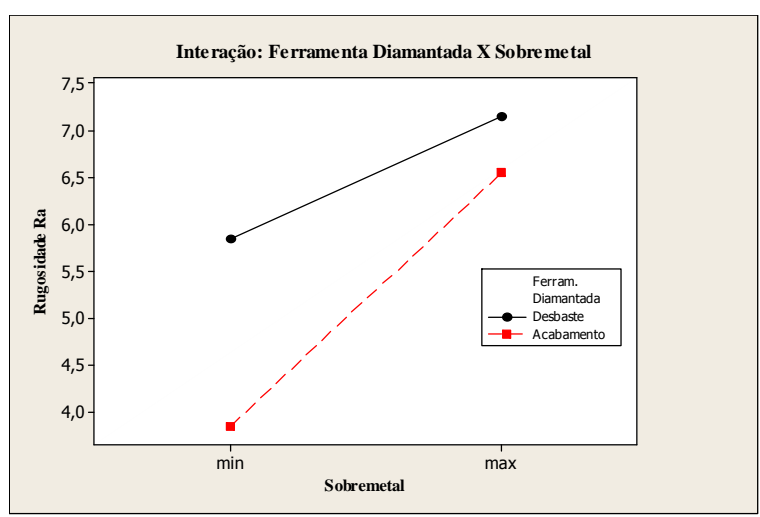

(f): Ferramenta Diamantada X Sobremetal

Figura 4.4 - Gráficos de interações entre os fatores para Rugosidade Ra. 
Os gráficos da Figura 4.4 demonstram todas as interações entre os fatores dois a dois e a indicação de relação entre os fatores é confirmada com a inclinação entre as retas:quanto maior a inclinação entre as retas maior é a relação entre os fatores. Para o caso da Rugosidade $\mathrm{Ra}$, as interações que podem apresentar alguma significância são as que têm o Sobremetal relacionado com outro fator, conforme representado nas Figuras 4.4(c), 4.4(e) e 4.4(f).

Entretanto, para o intervalo analisado, a interação entre a Ferramenta Diamantada e o Sobremetal é a mais significativa por apresentar o menor $P_{-}$valor abaixo de 0,050 conforme Tabela 4.2. Nas Figuras 4.4(c) e 4.4(e) pode ser observada a inclinação entre as retas, no entanto o P_valor da Tabela 4.2 acima de 0,050 determina a não significância das interações.

\section{$\underline{4.2-\text { Resultados referentes ao perpendicularismo do canal }}$}

Foi utilizada a ANOVA para determinar o grau de significância das variáveis independente de suas possíveis combinações

ANOVA para Perpendicularismo em função de: Velocidade, Passes, Ferramenta Diamantada e Sobremetal

Tabela 4.3 - Análise ANOVA do Perpendicularismo com os fatores analisados individualmente.

\begin{tabular}{|l|c|c|c|}
\hline Fator & Tipo & Níveis & Valores \\
\hline Veloc. & Fixo & 2 & $2 ; 6$ \\
\hline Passes & Fixo & 2 & $2 ; 6$ \\
\hline Ferram. Diamantada & Fixo & 2 & Desbaste; Acabamento \\
\hline Sobremetal & Fixo & 2 & min; max \\
\hline
\end{tabular}

\begin{tabular}{|l|c|c|c|c|c|}
\hline Fator de controle & $\begin{array}{c}\text { Grau de } \\
\text { liberdade }\end{array}$ & $\begin{array}{c}\text { Soma dos } \\
\text { quadrados }\end{array}$ & $\begin{array}{c}\text { Quadrado } \\
\text { médio }\end{array}$ & Teste F & Valor P \\
\hline Veloc. & 1 & 85,08 & 85,08 & 4,57 & 0,036 \\
\hline Passes & 1 & 89,25 & 89,25 & 4,79 & 0,032 \\
\hline Ferram. Diamantada & 1 & 56,95 & 56,95 & 3,06 & 0,084 \\
\hline Sobremetal & 1 & 593,51 & 593,51 & 31,86 & 0,000 \\
\hline Erro & 75 & 1397,16 & 18,63 & & \\
\hline Total & 79 & 2221,95 & & & \\
\hline
\end{tabular}


Na coluna $\mathrm{P}$ da análise de ANOVA, tem-se que os fatores Velocidade, Passes e Sobremetal são significativos para o intervalo de confiança de $95 \%$ e, portanto, interferem no resultado do perpendicularismo do canal. Para o fator Ferramenta Diamantada que apresenta o P_valor maior que 0,050, podemos afirmar que esta variável não é significativa para o Perpendicularismo nos níveis em que foram realizados os testes.

Na Figura 4.5 estão plotados os gráficos de resíduo para análise da normalidade dos dados.

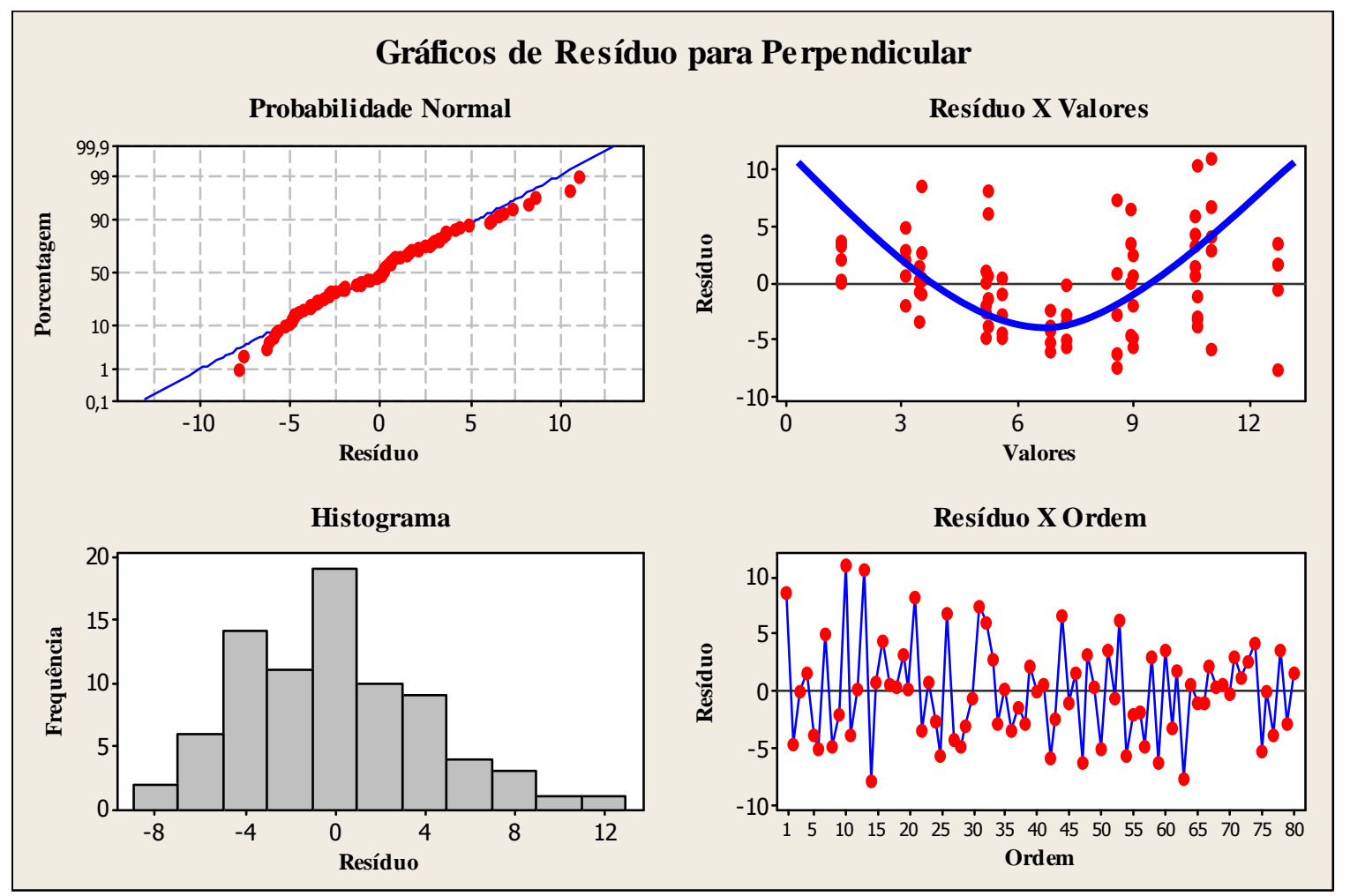

Figura 4.5 - Gráficos de Resíduo para Perpendicularismo.

Em análise da Figura 4.5, pode ser visualizado no gráfico de Probabilidade Normal que os dados do resíduo estão sobre a reta normal e no gráfico Histograma a distribuição também está próxima de uma normal, desta forma os gráficos confirmam a normalidade dos dados. O gráfico de Resíduo X Valor apresenta uma distribuição dos pontos com tendência à um gráfico de parábola conforme linha azul, indicando que o melhor modelo matemático para esta característica esteja próximo de uma função quadrática. 
Para a análise individual das variáveis foi utilizado o gráfico de efeitos que estão plotados na Figura 4.6.

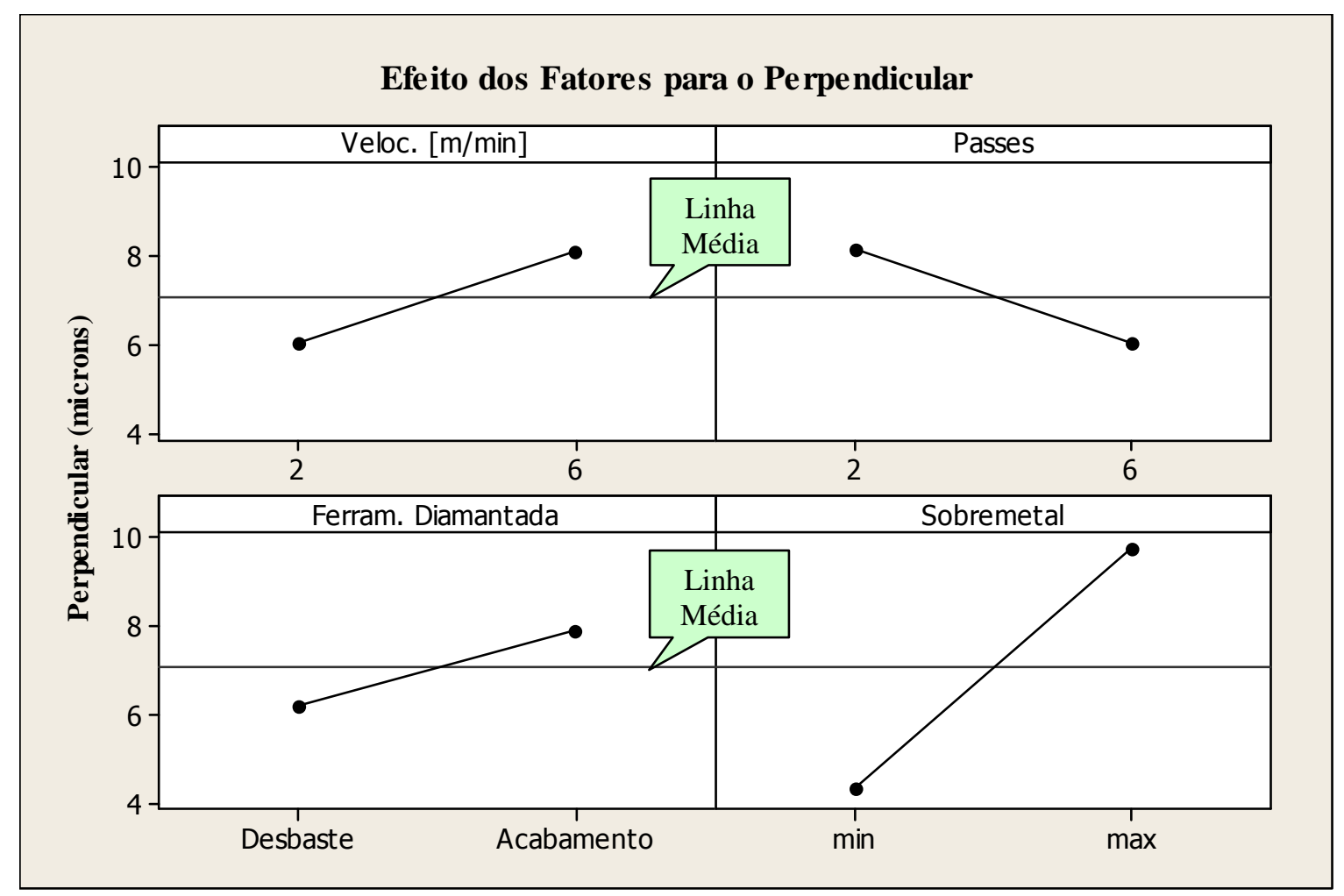

Figura 4.6 - Interferência das Variáveis no Processo para Perpendicularismo.

Nos Gráficos da Figura 4.6 verificamos que o fator Sobremetal apresenta a maior inclinação da reta em relação à linha média, por isto pode-se afirmar que individualmente esta variável apresenta maior interferência no processo se comparado com os demais fatores. A condição de menor erro de perpendicularismo é com o Sobremetal na condição de mínimo.

Para analisar a variância de cada um dos quatro fatores do estudo utilizou-se o "OneWay ANOVA“ do Minitab e os resultados estão registrados na Figura 4.7.

Velocidade $2 \mathrm{~m} / \mathrm{min}$

Velocidade $6 \mathrm{~m} / \mathrm{min}$

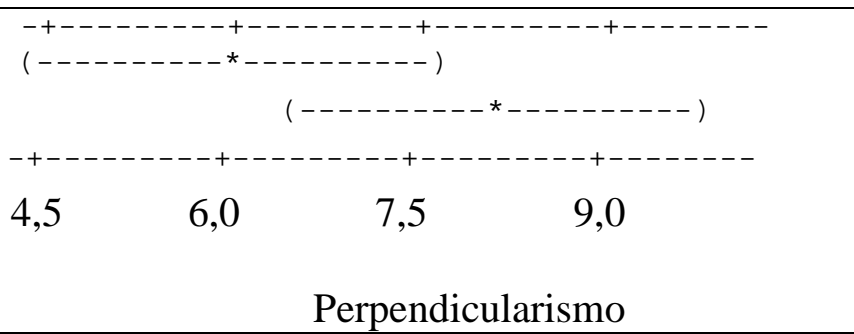

(a) - Intervalo de 95\% de confiança da média Perpendicular em função da Velocidade. 


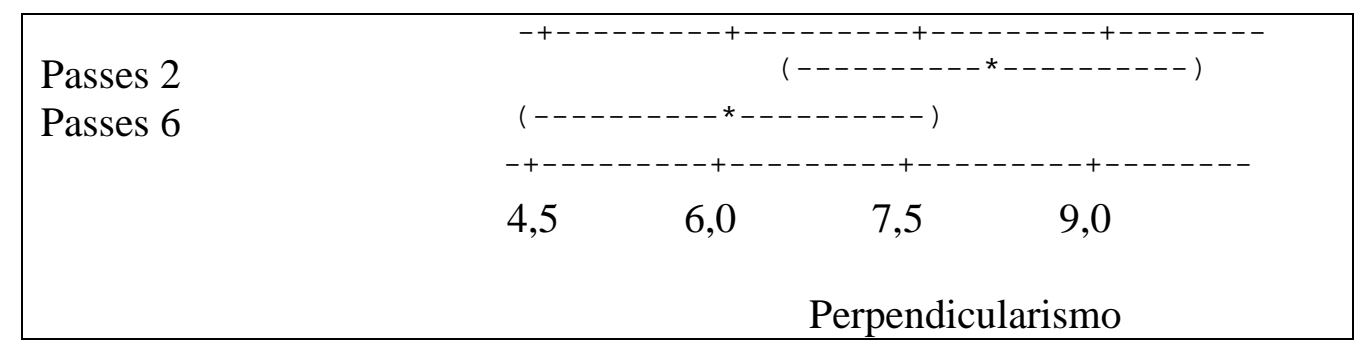

(b) - Intervalo de 95\% de confiança da média do Perpendicularismo em função dos Passes.

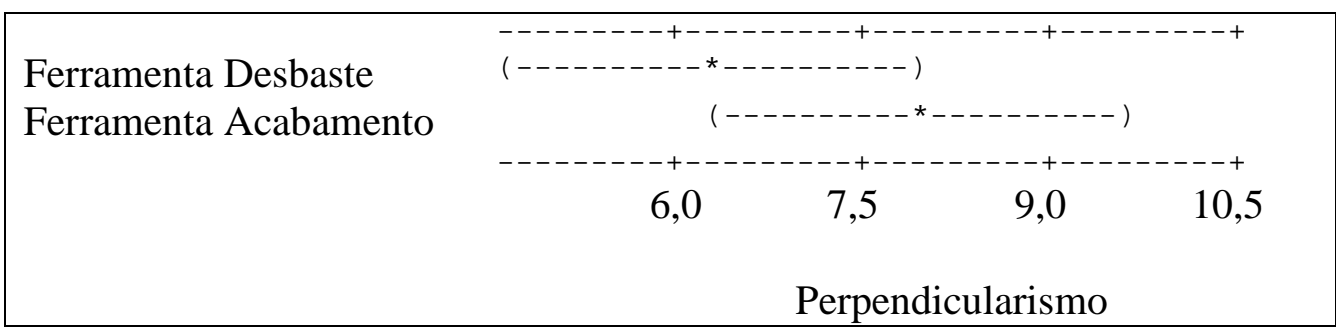

(c) - Intervalo de $95 \%$ de confiança da média do Perpendicularismo em função da Ferramenta Diamantada.

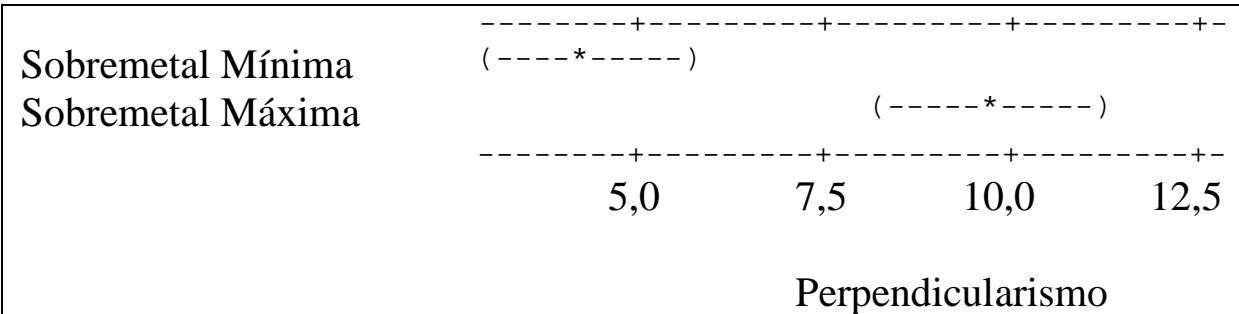

(d): Intervalo de 95\% de confiança da média do Perpendicularismo em função do Sobremetal.

Figura 4.7 - Analise do Intervalo de $95 \%$ de confiança para os quatro fatores em relação ao Perpendicularismo.

Podemos verificar nas Figuras 4.7(a), 4.7(b) e 4.7(c) que para os fatores Velocidade, Passes e Ferramenta Diamantada nos dois níveis em que foram analisados, os valores de Perpendicular encontrados para cada nível se sobrepõem em relação ao outro nível, demonstrando desta forma que estes fatores são pouco significativos para a característica. Para a variável Sobremetal, na Figura 4.7(d), onde os valores de Perpendicular não apresentam valores comuns entre os dois níveis, pode-se afirmar que este fator interfere de forma significativa no Perpendicular do canal.

Com a constatação da normalidade dos dados através dos Gráficos de Resíduo da Figura 4.5, analisou-se a combinação dos fatores para determinar se as relações determinam 
significância para o Perpendicularismo. Através da ANOVA, os dados foram relacionados dois a dois, sendo o resultado mostrado na Tabela 4.4.

Tabela 4.4 - Análise ANOVA do Perpendicular com os fatores combinados dois a dois.

\begin{tabular}{|l|c|c|c|c|c|}
\hline Fator de controle & $\begin{array}{c}\text { Grau de } \\
\text { liberdade }\end{array}$ & $\begin{array}{c}\text { Soma dos } \\
\text { quadrados }\end{array}$ & $\begin{array}{c}\text { Quadrado } \\
\text { médio }\end{array}$ & $\begin{array}{c}\text { Teste } \\
\text { F }\end{array}$ & $\begin{array}{c}\text { Valor } \\
\text { P }\end{array}$ \\
\hline Veloc. & 1 & 85,08 & 85,08 & 5,91 & 0,018 \\
\hline Passes & 1 & 89,25 & 89,25 & 6,20 & 0,015 \\
\hline Ferram. Diamantada & 1 & 56,95 & 56,95 & 3,95 & 0,051 \\
\hline Sobremetal & 1 & 593,51 & 593,51 & 41,21 & 0,000 \\
\hline Veloc. *Passes & 1 & 26,57 & 26,57 & 1,84 & 0,179 \\
\hline Veloc. *Ferram. Diamantada & 1 & 21,12 & 21,12 & 1,47 & 0,230 \\
\hline Veloc. *Sobremetal & 1 & 320,40 & 320,40 & 22,25 & 0,000 \\
\hline Passes *Ferram. Diamantada & 1 & 14,71 & 14,71 & 1,02 & 0,316 \\
\hline Passes *Sobremetal & 1 & 13,53 & 13,53 & 0,94 & 0,336 \\
\hline Ferram. Diamantada *Sobremetal & 1 & 7,14 & 7,14 & 0,50 & 0,484 \\
\hline Erro & 69 & 993,71 & 14,40 & & \\
\hline Total & 79 & 2221,95 & & & \\
\hline
\end{tabular}

Na coluna $\mathrm{P}$ da Tabela 4.4 podemos identificar que apenas a combinação entre Velocidade e Sobremetal é significante para os resultados do Perpendicularismo, sendo que as demais combinações não apresentam significâncias para a característica. Para ilustrar estas relações foram plotados os gráficos de Interação dos Fatores dois a dois através do ANOVA. Os resultados estão ilustrados na Figura 4.8.

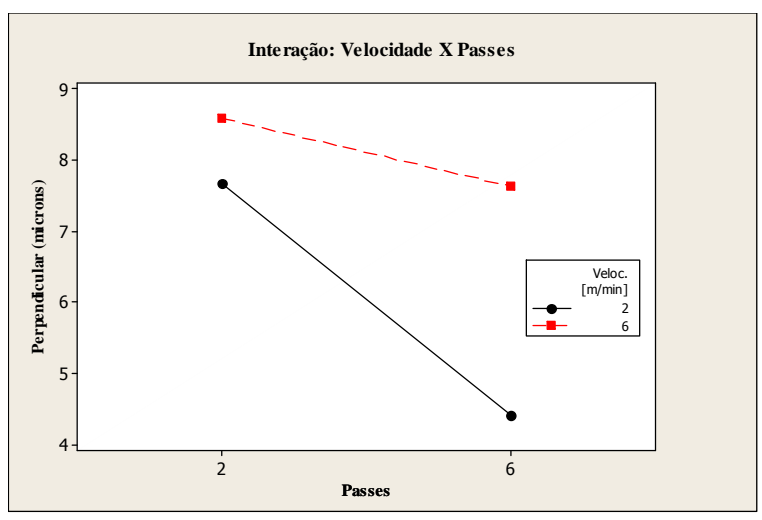

(a) - Velocidade X Passes

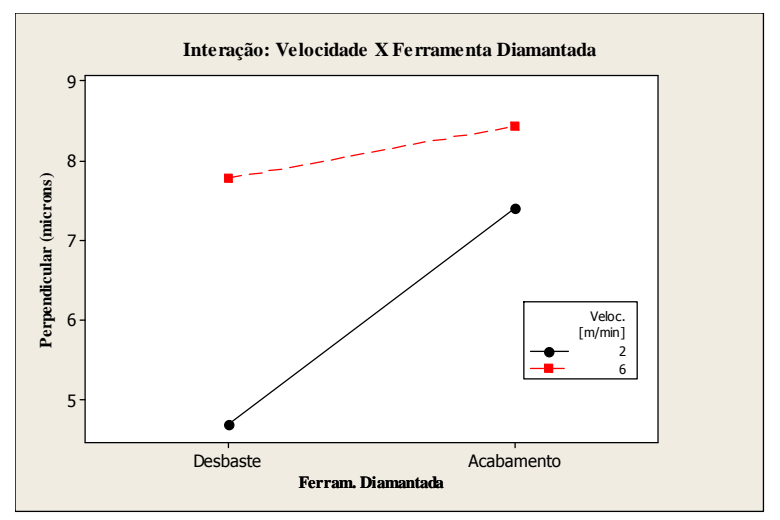

(b) - Velocidade X Ferramenta Diamantada 


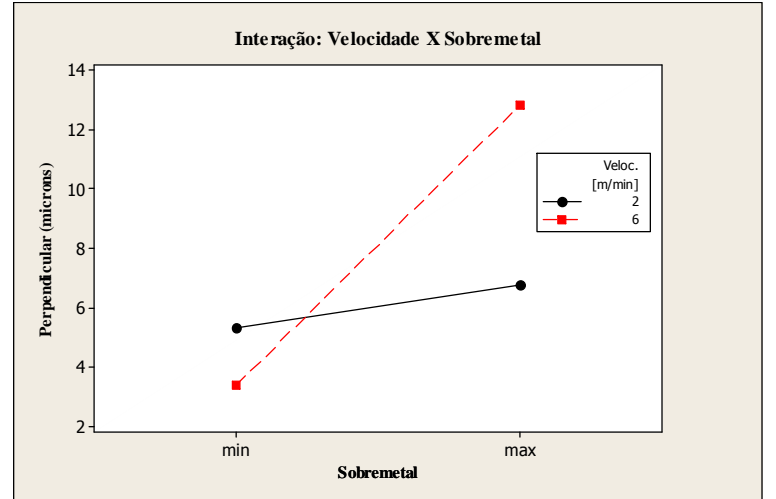

(c) - Velocidade X Sobremetal

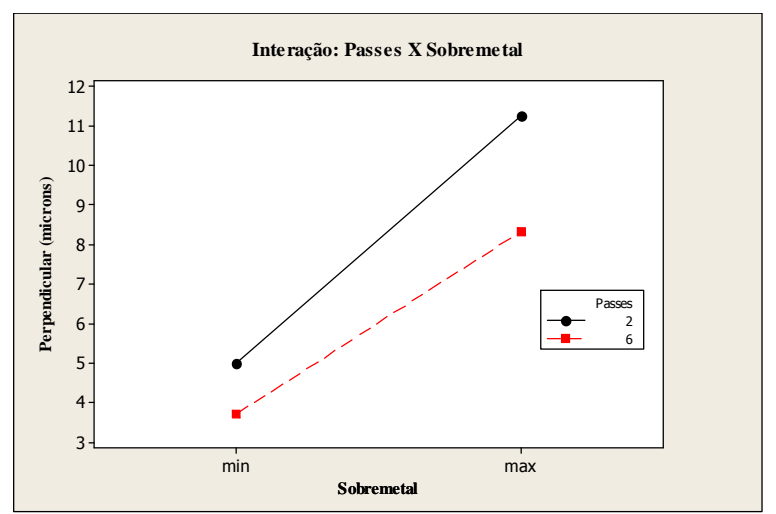

(e) - Passes X Sobremetal

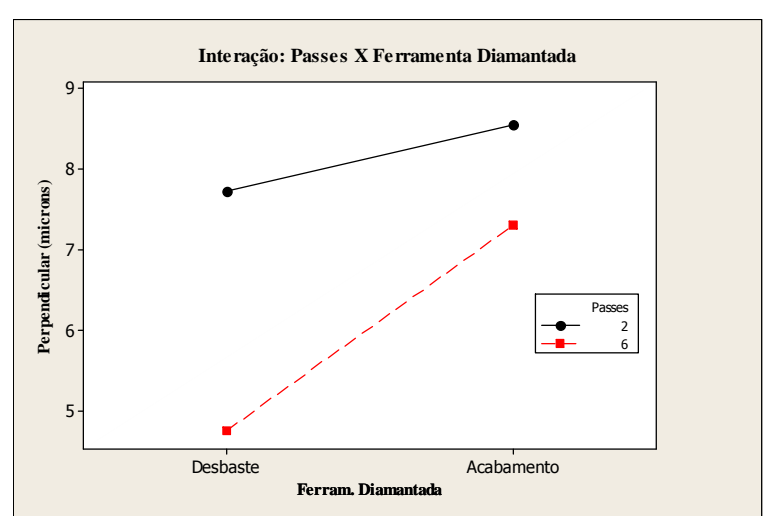

(d) - Passes X Ferramenta Diamantada

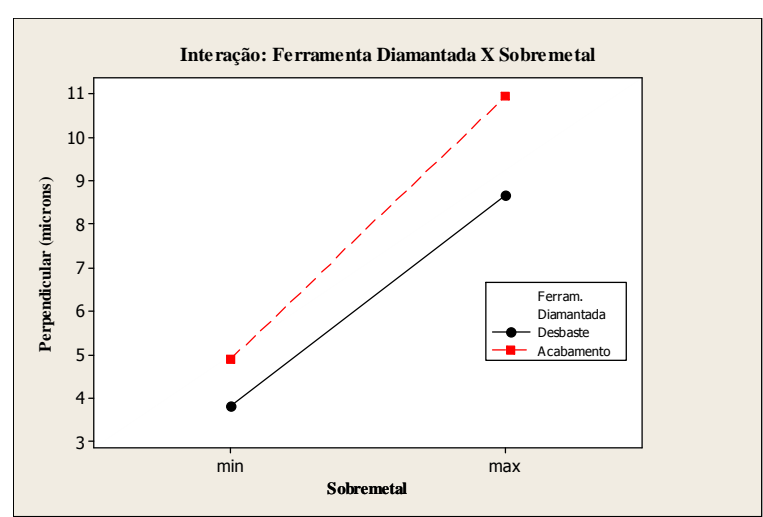

(f) - Ferramenta Diamantada X Sobremetal

Figura 4.8 - Gráficos de interações entre os fatores para Perpendicular.

Os gráficos da Figura 4.8 demonstram as interações entre os fatores dois a dois. Para o caso do Perpendicularismo do canal, a interação que apresenta significância é a que relaciona Velocidade e o Sobremetal, o cruzamento entre as retas na Figura 4.8(c) confirma a significância já determinada pelo P_valor da Tabela 4.4.

\section{3- Resultados referentes à Conicidade Horizontal das faces do canal}

O termo conicidade é normalmente empregado para figuras geométricas cilíndricas, mas neste trabalho o termo conicidade está sendo utilizado para indicar a inclinação entre as faces do canal, como o bloco é referenciado na base do calibrador por uma de suas faces retificadas, a direção da inclinação das faces do canal será indicada por horizontal ou vertical, portanto, neste caso, a Conicidade Horizontal refere-se à inclinação entre as faces do canal brochado no sentido radial da peça. 
Foi utilizada a ANOVA para determinar o grau de significância das variáveis independente de suas possíveis combinações

ANOVA para Conicidade Horizontal em função de: Velocidade, Passes, Ferramenta Diamantada e Sobremetal.

Tabela 4.5: Análise ANOVA da Conicidade Horizontal com os fatores individuais.

\begin{tabular}{|l|c|c|c|}
\hline Fator & Tipo & Níveis & Valores \\
\hline Veloc. & Fixo & 2 & $2 ; 6$ \\
\hline Passes & Fixo & 2 & $2 ; 6$ \\
\hline Ferram. Diamantada & Fixo & 2 & Desbaste; Acabamento \\
\hline Sobremetal & Fixo & 2 & min; max \\
\hline
\end{tabular}

\begin{tabular}{|l|c|c|c|c|c|}
\hline Fator de controle & $\begin{array}{c}\text { Grau de } \\
\text { liberdade }\end{array}$ & $\begin{array}{c}\text { Soma dos } \\
\text { quadrados }\end{array}$ & $\begin{array}{c}\text { Quadrado } \\
\text { médio }\end{array}$ & Teste F & Valor P \\
\hline Veloc. & 1 & 14,54 & 14,54 & 1,00 & 0,320 \\
\hline Passes & 1 & 38,23 & 38,23 & 2,63 & 0,109 \\
\hline Ferram. Diamantada & 1 & 2997,58 & 2997,58 & 206,48 & 0,000 \\
\hline Sobremetal & 1 & 5,46 & 5,46 & 0,38 & 0,542 \\
\hline Erro & 75 & 1088,84 & 14,52 & & \\
\hline Total & 79 & 4144,63 & & & \\
\hline
\end{tabular}

Na coluna P da análise de ANOVA, tem-se que apenas o fator Ferramenta Diamantada é significativo, podendo desta forma concluir que este fator é determinante para os valores obtidos para a Conicidade Horizontal do canal. Os demais fatores não são representativos se considerados individualmente, já que o P_valor para estes fatores são maiores que 0,050 . Na Figura 4.9 estão plotados os gráficos de resíduos para análise da normalidade dos dados. 


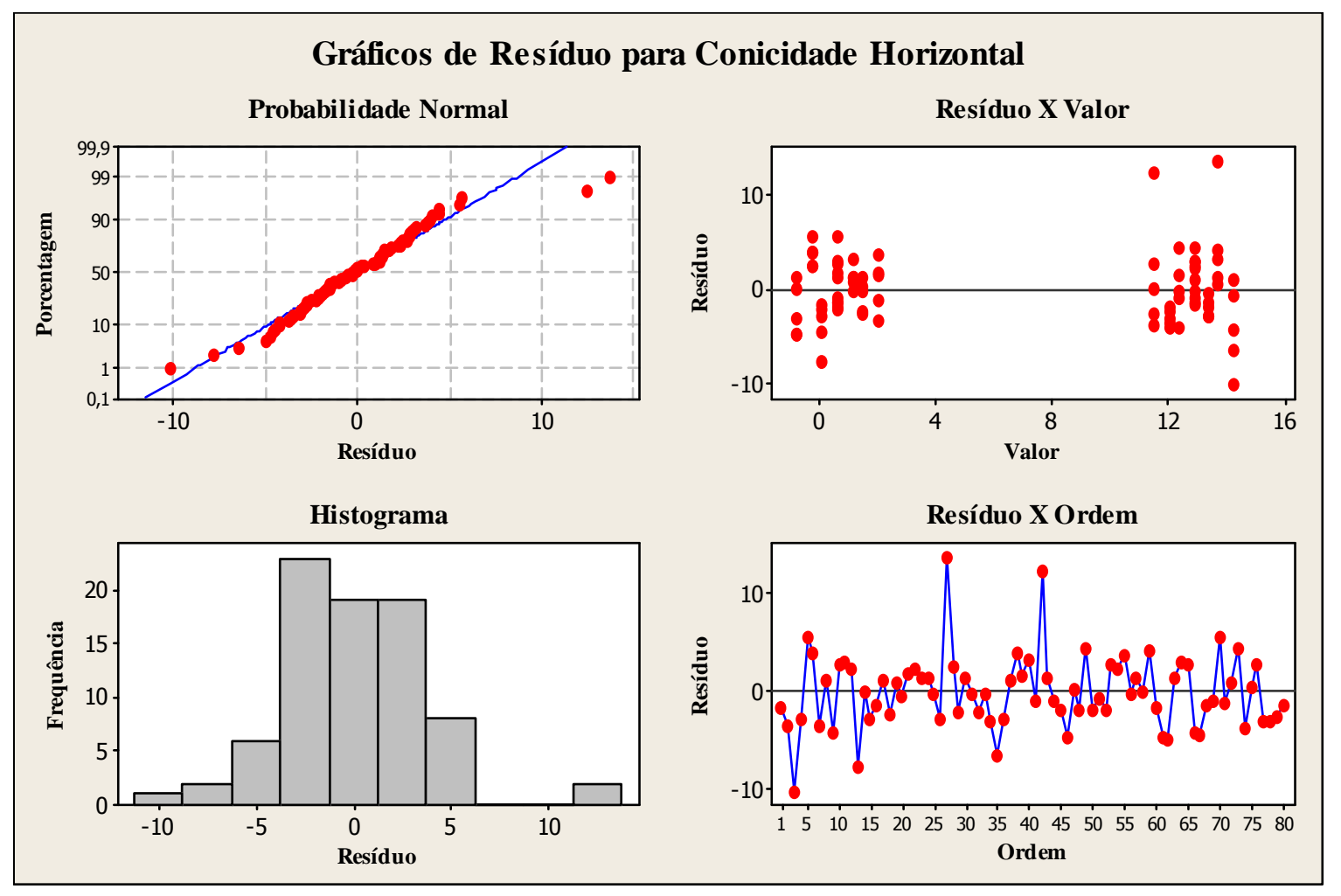

Figura 4.9 - Gráficos de Resíduo para Conicidade Horizontal.

Na Figura 4.9 observamos que no gráfico de Probabilidade Normal os dados dos resíduos estão sobre a reta normal. No gráfico Histograma a distribuição também está próxima de uma normal. O gráfico de Resíduo X Valor apresenta os pontos aglomerados em duas regiões, uma próxima do valor 1 e a outra próxima do valor 14. Esta situação mostra que o modelo matemático não é adequado. Já o gráfico Resíduo X Ordem apresenta uma dispersão uniforme no período em que as peças foram usinadas.

Para a análise individual das variáveis foi utilizado o gráfico de efeitos. O gráfico da Figura 4.10 representa o efeito individual das variáveis. 


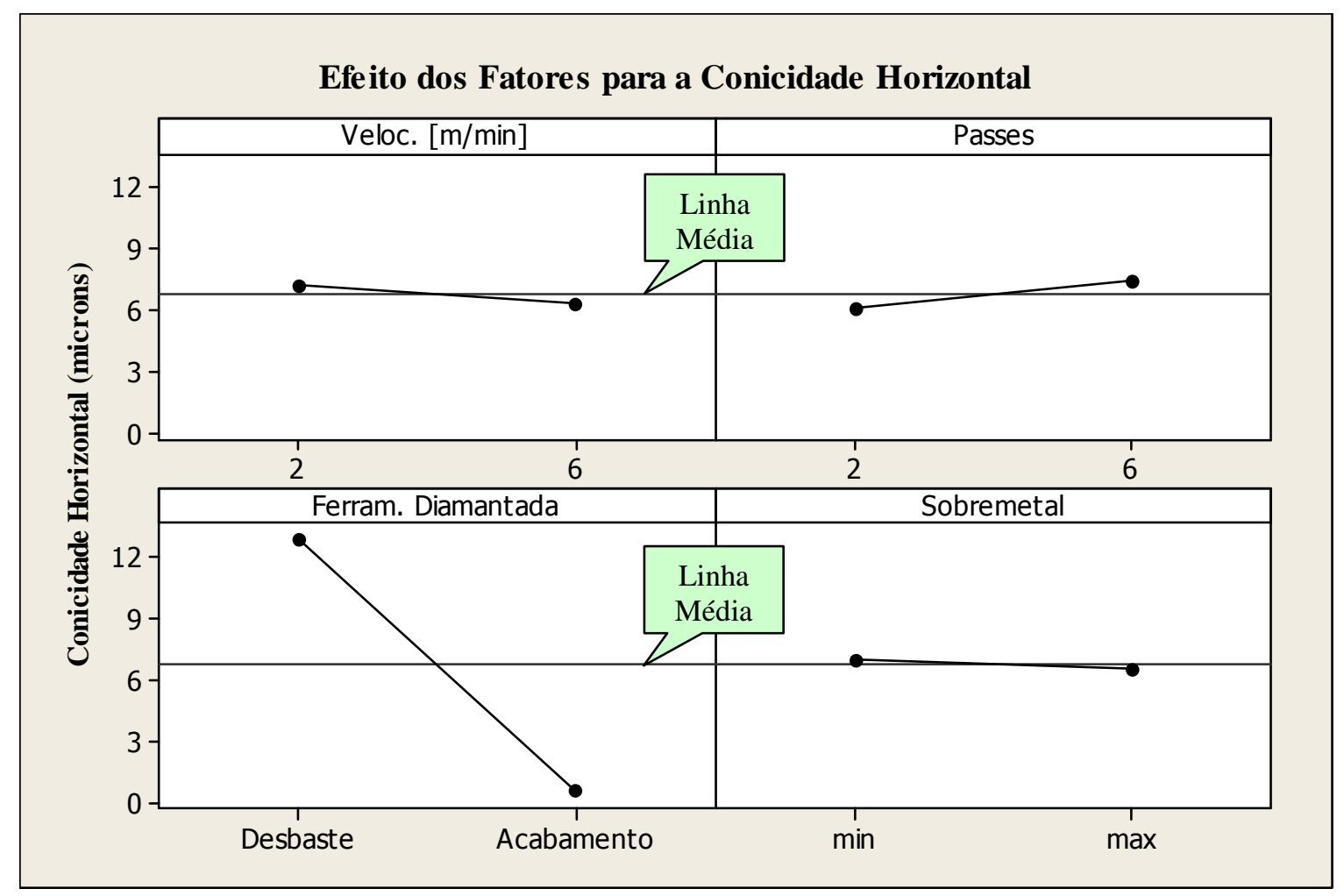

Figura 4.10 - Interferência das Variáveis no Processo para Conicidade Horizontal.

Nos Gráficos da Figura 4.10 podemos observar que o fator Ferramenta Diamantada apresenta a maior inclinação da reta em relação à linha média, por isto pode-se afirmar que individualmente esta variável apresenta maior interferência no processo se comparado com os demais fatores. A situação em que a conicidade horizontal tende ao menor erro é com a ferramenta diamantada de acabamento.

Para analisar a variância de cada um dos quatro fatores do estudo utilizou-se o "OneWay ANOVA“ também do Minitab, sendo que os resultados estão registrados na Figura 4.11.

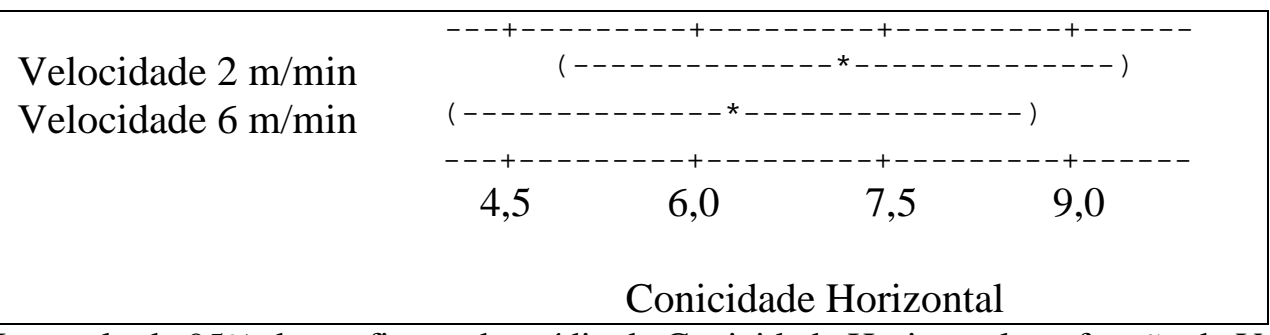

(a) - Intervalo de 95\% de confiança da média da Conicidade Horizontal em função da Velocidade. 


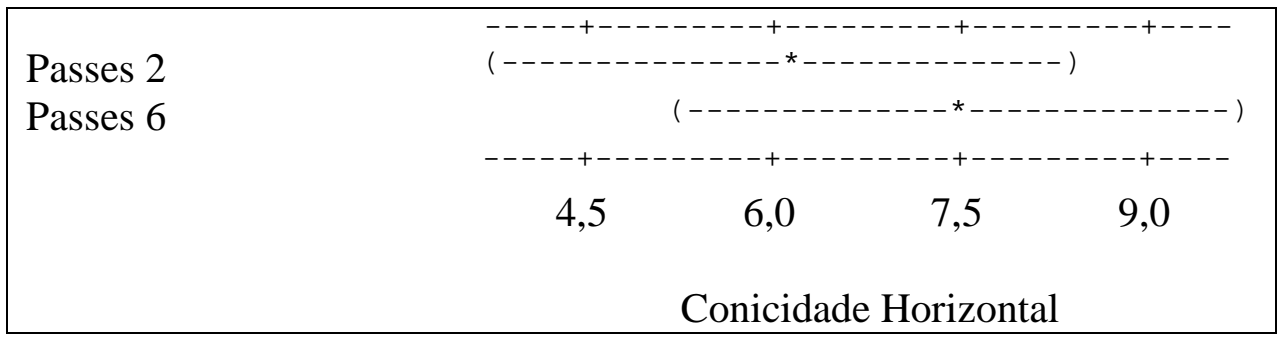

(b) - Intervalo de 95\% de confiança da média da Conicidade Horizontal em função de Passes.

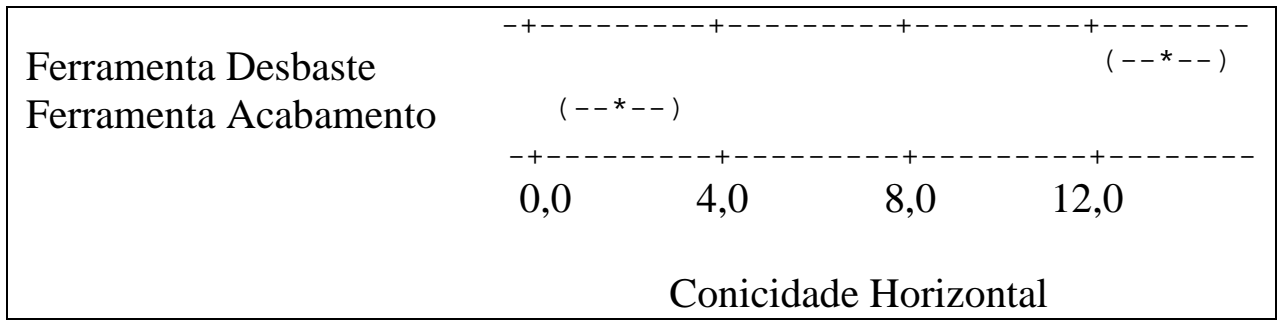

(c) - Intervalo de $95 \%$ de confiança da média da Conicidade Horizontal em função da Ferramenta Diamantada.

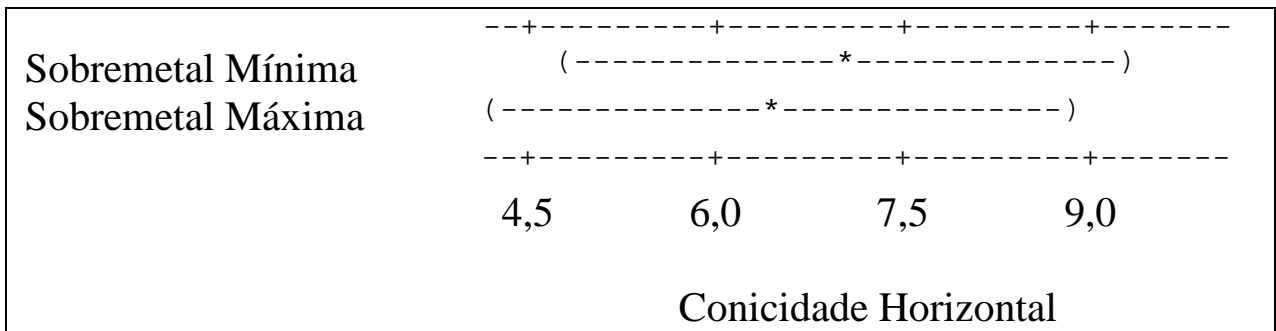

(d) - Intervalo de 95\% de confiança da média da Conicidade Horizontal em função do Sobremetal.

Figura 4.11 - Analise do Intervalo de 95\% de confiança para os quatro fatores.

Nas Figuras 4.11(a), 4.11(b) e 4.11(d) pode-se verificar a proximidade das médias das conicidades para os dois níveis de cada fator, o que implica na não significância dos fatores Velocidade, Passes e Sobremetal para os valores obtidos com a Conicidade Horizontal. O fator Ferramenta Diamantada que apresentou o P_valor de 0,000 na Análise da ANOVA, na Figura 4.11(e) pode ser visualizado como significante por ter suas médias de Conicidade Horizontal bem distintas.

Após a verificação individual dos fatores, foram analisadas suas combinações para determinar quais delas apresentam alterações na Conicidade Horizontal, ou seja, se estas interações apresentam significância para o estudo. Através da ANOVA obtiveram-se os dados das combinações entre os fatores dois a dois, conforme Tabela 4.6. 
Tabela 4.6 - Análise ANOVA da Conicidade Horizontal com os fatores combinados dois a dois.

\begin{tabular}{|l|c|c|c|c|c|}
\hline Fator de controle & $\begin{array}{c}\text { Grau de } \\
\text { liberdade }\end{array}$ & $\begin{array}{c}\text { Soma dos } \\
\text { quadrados }\end{array}$ & $\begin{array}{c}\text { Quadrado } \\
\text { médio }\end{array}$ & $\begin{array}{c}\text { Teste } \\
\mathrm{F}\end{array}$ & $\begin{array}{c}\text { Valor } \\
\mathrm{P}\end{array}$ \\
\hline Veloc. & 1 & 14,54 & 14,54 & 1,44 & 0,234 \\
\hline Passes & 1 & 38,23 & 38,23 & 3,78 & 0,056 \\
\hline Ferram. Diamantada & 1 & 2997,58 & 2997,58 & 296,65 & 0,000 \\
\hline Sobremetal & 1 & 5,46 & 5,46 & 0,54 & 0,465 \\
\hline Veloc. *Passes & 1 & 0,19 & 0,19 & 0,02 & 0,891 \\
\hline Veloc. *Ferram. Diamantada & 1 & 19,50 & 19,50 & 1,93 & 0,169 \\
\hline Veloc. *Sobremetal & 1 & 0,14 & 0,14 & 0,01 & 0,908 \\
\hline Passes *Ferram. Diamantada & 1 & 0,41 & 0,41 & 0,04 & 0,842 \\
\hline Passes *Sobremetal & 1 & 86,74 & 86,74 & 8,58 & 0,000 \\
\hline Ferram. Diamantada *Sobremetal & 1 & 284,64 & 284,64 & 28,17 & 0,005 \\
\hline Erro & 69 & 697,23 & 10,10 & & \\
\hline Total & 79 & 4144,63 & & & \\
\hline
\end{tabular}

Na coluna P da Tabela 4.6 tem-se duas interações com significância para a Conicidade Horizontal. A interação entre Passes e Sobremetal com um P_valor de 0,005 apresenta significância, embora nenhum dos fatores sejam significantes se tratados separadamente. A interação Ferramenta Diamantada e Sobremetal também tem significância com um P_valor de 0,000, sendo que na análise anterior foi constatada a significância do fator Ferramenta Diamantada em condição isolada.

Por esta análise podemos supor que as interações nem sempre afetam a característica da mesma forma que os fatores isolados. A Figura 4.12 contém os gráficos das interações para análise visual.

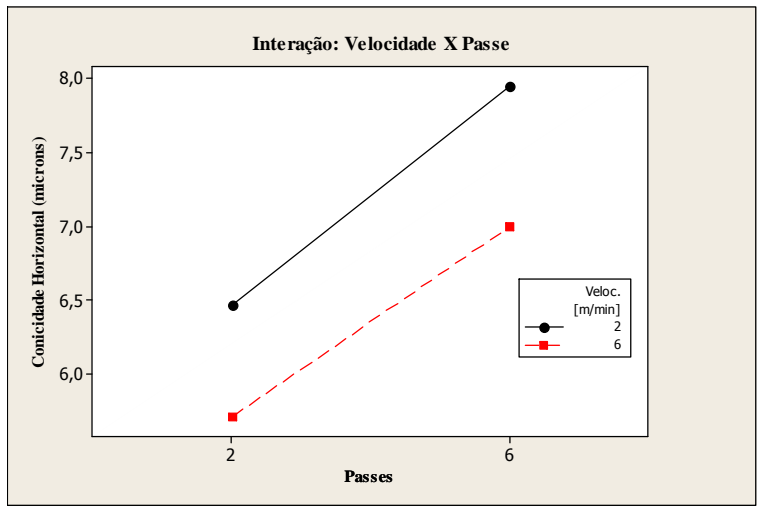

(a): Velocidade X Passe

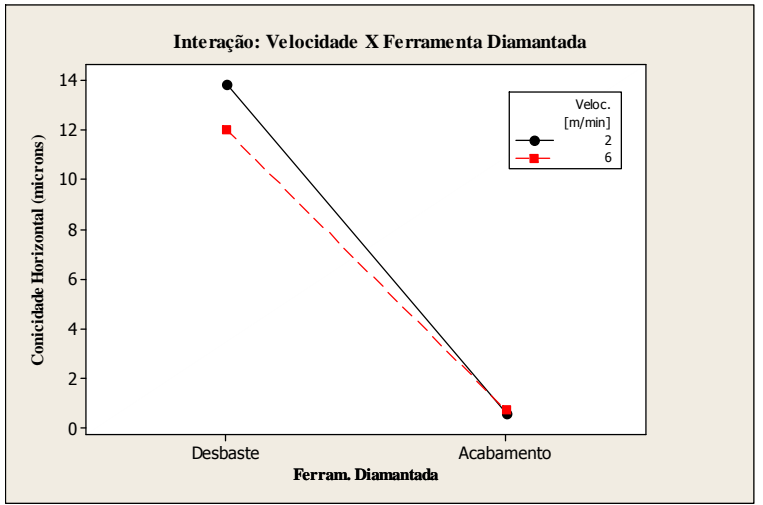

(b): Velocidade X Ferramenta Diamantada 


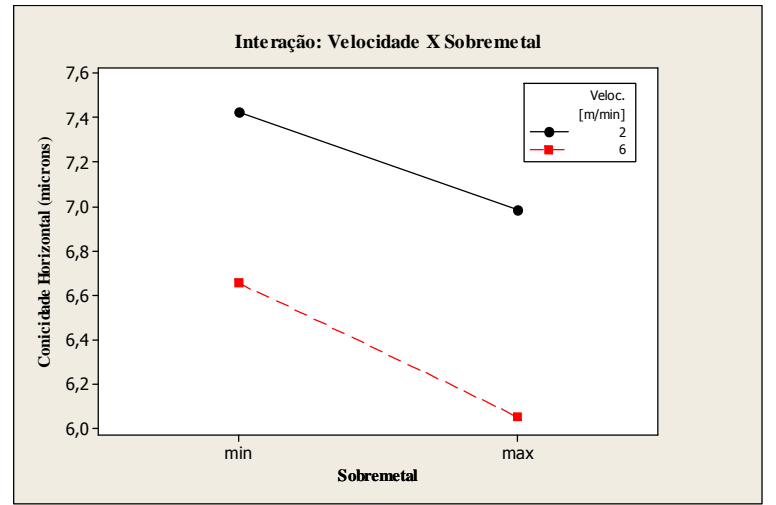

(c): Velocidade X Sobremetal

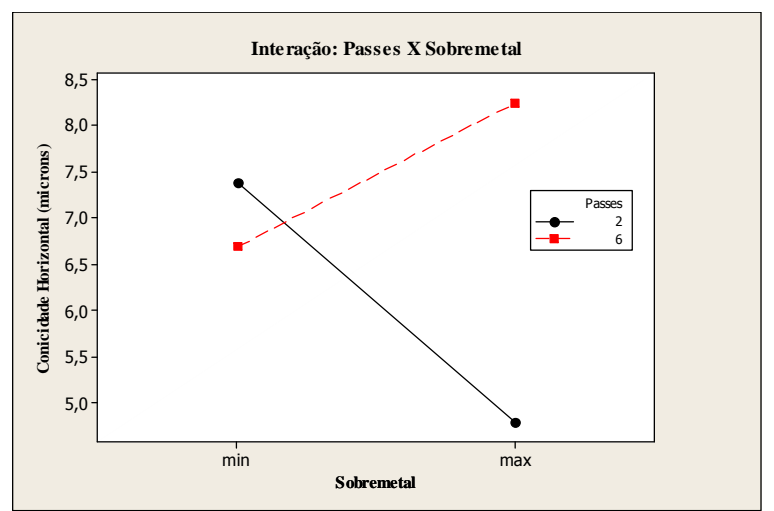

(e): Passes X Sobremetal

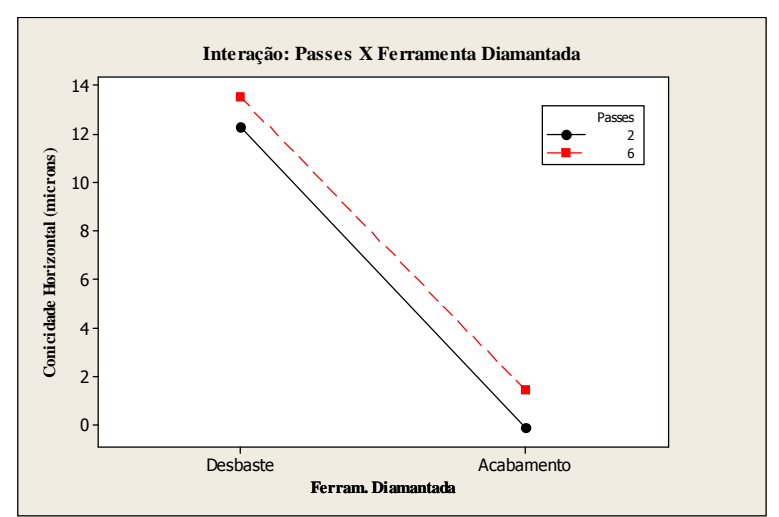

(d): Passe X Ferramenta Diamantada

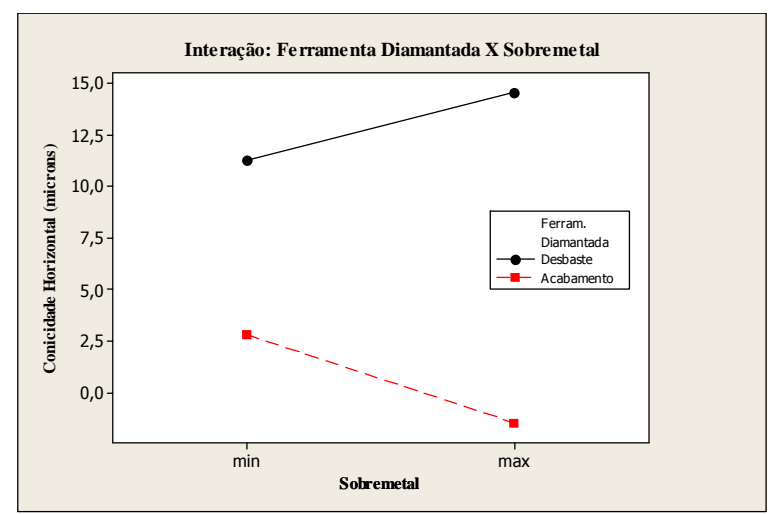

(f): Ferramenta Diamantada X Sobremetal

Figura 4.12 - Gráficos das interações entre os fatores Para Conicidade Horizontal.

Os gráficos plotados na Figura 4.12 confirmam a significância das interações conforme a análise feita da Tabela 4.6, onde pode ser observado o cruzamento das retas na interação entre Passes e Sobremetal da Figura 4.12(e) que, além do cruzamento entre as retas, a inclinação entre estas apresenta um ângulo maior que o visualizado na interação entre Ferramenta Diamantada e Sobremetal representada na Figura 4.12(f), no entanto esta ultima interação também apresenta interferência das combinações no resultado da Conicidade Horizontal, conforme o P_valor de 0,005 determinado na tabela 4.6.

\section{4- Resultados referentes à Conicidade Vertical das faces do canal}

Neste caso, a Conicidade Vertical refere-se à inclinação das faces do canal no sentido axial da peça. 
Foi utilizada a ANOVA para determinar o grau de significância das variáveis independente de suas possíveis combinações.

ANOVA para Conicidade Vertical em função de: Velocidade, Passes, Ferramenta Diamantada e Sobremetal.

Tabela 4.7 - Análise ANOVA da Conicidade Vertical com os fatores individuais.

\begin{tabular}{|l|c|c|c|}
\hline Fatores & Tipo & Níveis & Valores \\
\hline Veloc. & fixo & 2 & $2 ; 6$ \\
\hline Ferram. Diamantada & fixo & 2 & Desbaste; Acabamento \\
\hline Sobremetal & fixo & 2 & min; max \\
\hline Passes & fixo & 2 & $2 ; 6$ \\
\hline
\end{tabular}

\begin{tabular}{|l|c|c|c|c|c|}
\hline Fator de controle & $\begin{array}{c}\text { Grau de } \\
\text { liberdade }\end{array}$ & $\begin{array}{c}\text { Soma dos } \\
\text { quadrados }\end{array}$ & $\begin{array}{c}\text { Quadrado } \\
\text { médio }\end{array}$ & Teste F & Valor P \\
\hline Veloc. & 1 & 0,231 & 0,231 & 0,03 & 0,874 \\
\hline Ferram. Diamantada & 1 & 4,465 & 4,465 & 0,49 & 0,488 \\
\hline Sobremetal & 1 & 237,705 & 237,705 & 25,91 & 0,000 \\
\hline Passes & 1 & 0,861 & 0,861 & 0,09 & 0,760 \\
\hline Erro & 75 & 688,136 & 9,175 & & \\
\hline Total & 79 & 931,399 & & & \\
\hline
\end{tabular}

Na coluna $\mathrm{P}$ da análise de variância, tem-se que apenas o fator Sobremetal é significante para o intervalo de confiança de $95 \%$ e, portanto, é determinante para o resultado da Conicidade Vertical das faces do canal. Os demais fatores, Velocidade, Ferramenta Diamantada e Passes que apresentam o P_valor maior que 0,050, podemos afirmar que estas variáveis não são significativas para a Conicidade Vertical nos níveis em que foram realizados os testes.

Na Figura 4.13 estão plotados os gráficos de resíduos para análise da normalidade dos dados. 


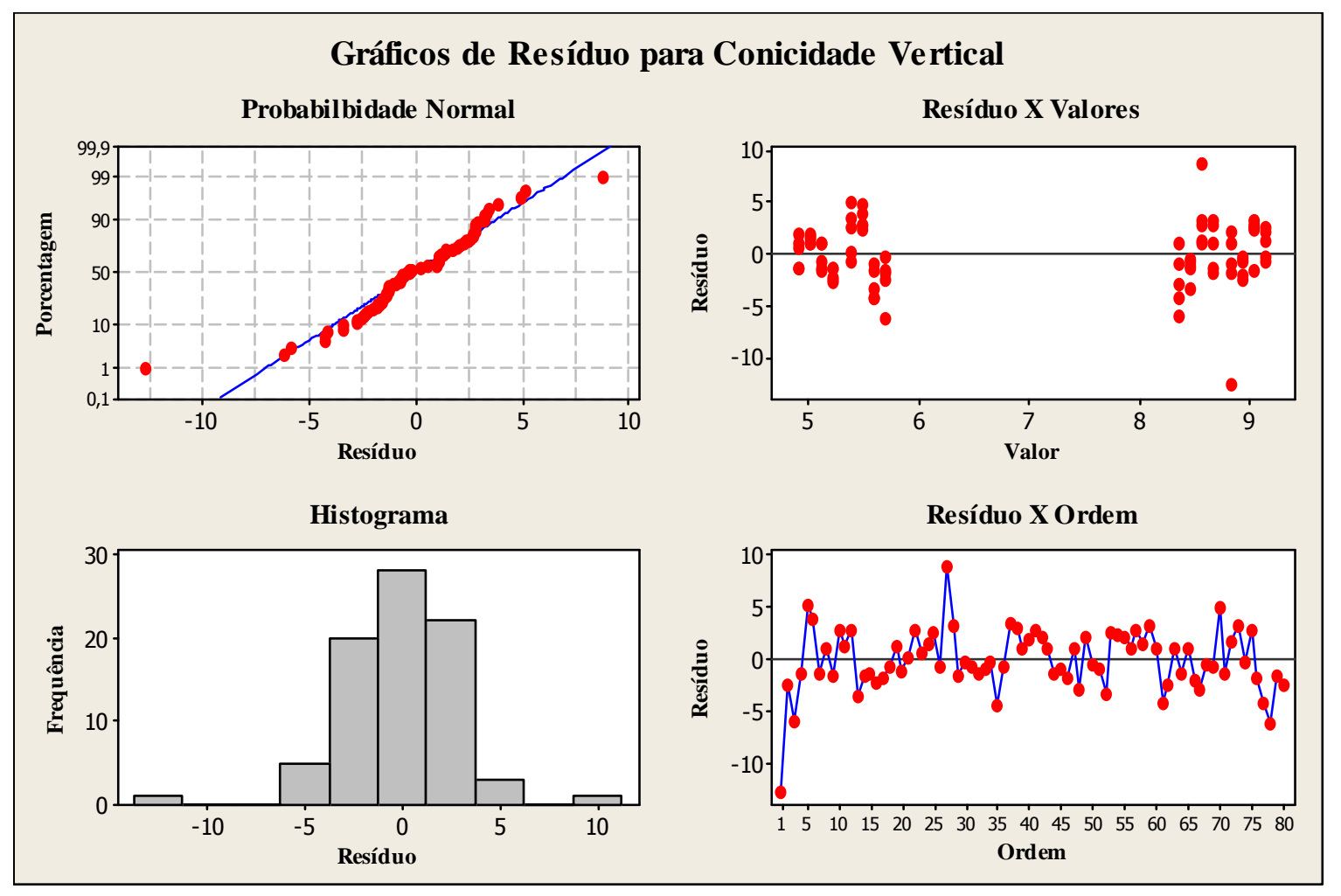

Figura 4.13 - Gráficos de Resíduo para Conicidade Vertical.

Na Figura 4.13 observamos que no gráfico de Probabilidade Normal os dados dos resíduos estão sobre a reta normal. No gráfico Histograma a distribuição também está próxima de uma normal. O gráfico de Resíduo X Valor apresenta os pontos aglomerados em duas regiões, uma próxima do valor 4 e a outra próxima do valor 9 , mostrando uma dispersão não uniforme para os valores medidos. O gráfico Resíduo X Ordem apresenta uma dispersão uniforme no período em que as peças foram usinadas, mostrando a não interferência de agentes externos nas medições.

Para a análise individual das variáveis foi utilizado o gráfico de efeitos. O gráfico da Figura 4.14 representa o efeito individual das variáveis. 


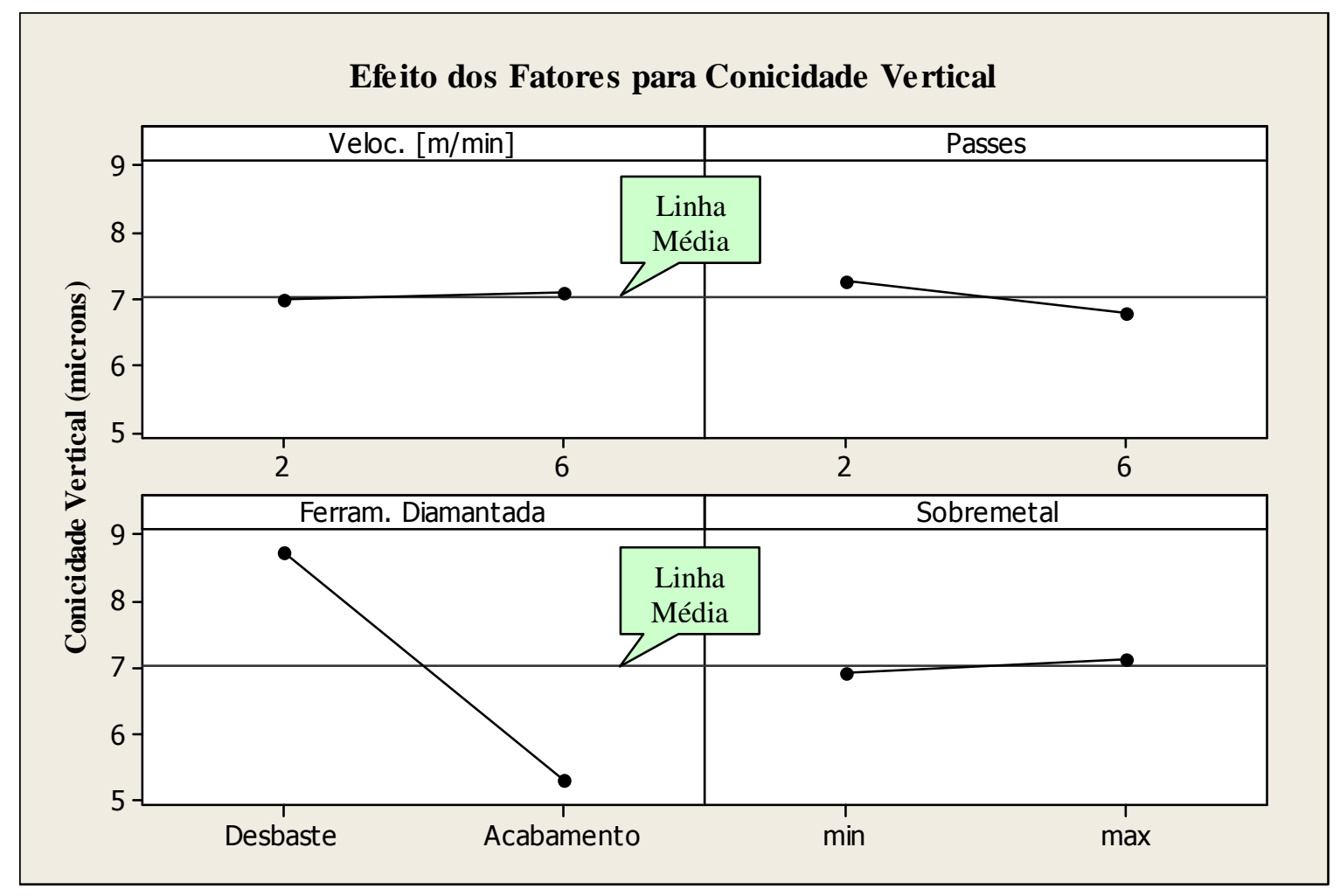

Figura 4.14 - Interferência das Variáveis no Processo para Conicidade Vertical.

Nos gráficos da Figura 4.14 podemos observar que o fator Ferramenta Diamantada apresenta a maior inclinação da reta em relação à linha média, por isto pode-se afirmar que individualmente esta variável apresenta maior interferência no processo se comparado com os demais fatores. A situação em que a Conicidade Vertical tende ao menor erro é com a Ferramenta Diamantada de acabamento.

Para analisar a variância de cada um dos quatro fatores do estudo utilizou-se o "OneWay ANOVA“ também do Minitab e os resultados estão registrados na Figura 4.15.

\begin{tabular}{|c|c|c|c|c|}
\hline \multirow{3}{*}{$\begin{array}{l}\text { Velocidade } 2 \mathrm{~m} / \mathrm{min} \\
\text { Velocidade } 6 \mathrm{~m} / \mathrm{min}\end{array}$} & \multicolumn{4}{|c|}{ 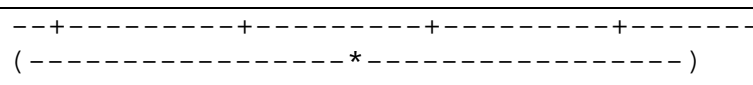 } \\
\hline & & -- & $\star---$ & $--------)$ \\
\hline & 6,00 & 6,60 & 7,20 & 7,80 \\
\hline
\end{tabular}

(a) - Intervalo de 95\% de confiança da média da Conicidade Vertical em função da Velocidade. 
Passes 2

Passes 6

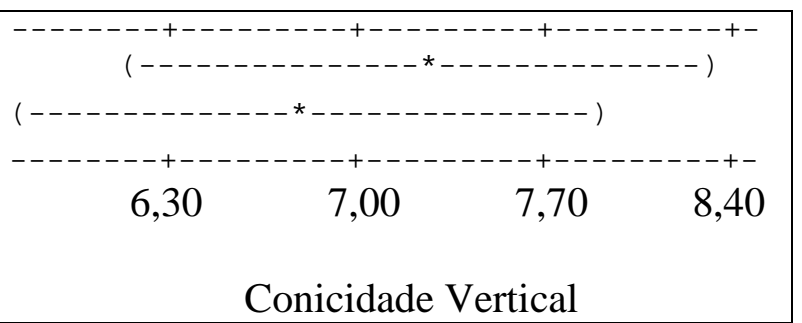

Conicidade Vertical

(b) - Intervalo de 95\% de confiança da média da Conicidade Vertical em função de Passes.

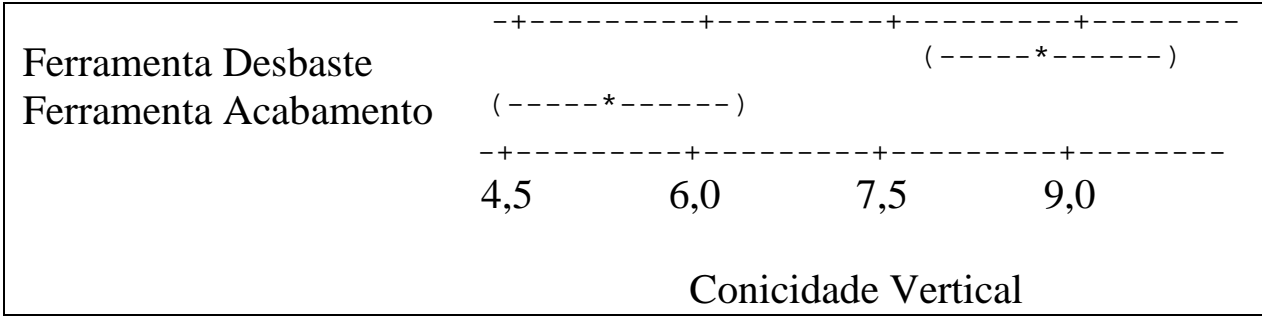

(c) - Intervalo de 95\% de confiança da média da Conicidade Vertical em função de Ferramenta Diamantada.

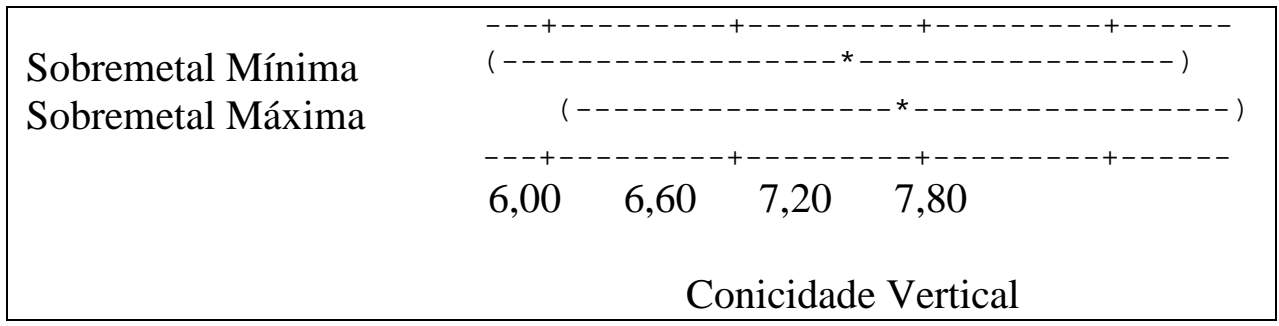

(d) - Intervalo de 95\% de confiança da média da Conicidade Vertical em função do Sobremetal.

Figura 4.15 - Análise do Intervalo de 95\% de confiança para os quatro fatores.

Com a constatação da normalidade dos dados, analisou-se a combinação dos fatores para determinar se as combinações destes apresentam alterações na Conicidade Vertical, ou seja, se as interações apresentam significância para o estudo. Pela análise com a ANOVA foram encontrados os dados da Tabela 4.8.

Tabela 4.8 - Análise ANOVA da Conicidade Vertical com os fatores combinados dois a dois.

\begin{tabular}{|l|c|c|c|c|c|}
\hline Fator de controle & $\begin{array}{c}\text { Grau de } \\
\text { liberdade }\end{array}$ & $\begin{array}{c}\text { Soma dos } \\
\text { quadrados }\end{array}$ & $\begin{array}{c}\text { Quadrado } \\
\text { médio }\end{array}$ & $\begin{array}{c}\text { Teste } \\
\mathrm{F}\end{array}$ & $\begin{array}{c}\text { Valor } \\
\mathrm{P}\end{array}$ \\
\hline Veloc. & 1 & 0,231 & 0,231 & 0,04 & 0,833 \\
\hline Passes & 1 & 4,465 & 4,465 & 0,86 & 0,356 \\
\hline Ferram. Diamantada & 1 & 237,705 & 237,705 & 45,98 & 0,000 \\
\hline Sobremetal & 1 & 0,861 & 0,861 & 0,17 & 0,684 \\
\hline Veloc. *Passes & 1 & 4,851 & 4,851 & 0,94 & 0,336 \\
\hline
\end{tabular}




\begin{tabular}{|l|c|c|c|c|c|}
\hline Fator de controle & $\begin{array}{c}\text { Grau de } \\
\text { liberdade }\end{array}$ & $\begin{array}{c}\text { Soma dos } \\
\text { quadrados }\end{array}$ & $\begin{array}{c}\text { Quadrado } \\
\text { médio }\end{array}$ & $\begin{array}{c}\text { Teste } \\
\mathrm{F}\end{array}$ & $\begin{array}{c}\text { Valor } \\
\mathrm{P}\end{array}$ \\
\hline Veloc. *Ferram. Diamantada & 1 & 1,596 & 1,596 & 0,31 & 0,580 \\
\hline Veloc. *Sobremetal & 1 & 29,403 & 29,403 & 5,69 & 0,000 \\
\hline Passes *Ferram. Diamantada & 1 & 0,861 & 0,861 & 0,17 & 0,684 \\
\hline Passes *Sobremetal & 1 & 22,791 & 22,791 & 4,41 & 0,020 \\
\hline Ferram. Diamantada *Sobremetal & 1 & 271,953 & 271,953 & 52,61 & 0,039 \\
\hline Erro & 69 & 356,681 & 5,169 & & \\
\hline Total & 79 & 931,399 & & & \\
\hline
\end{tabular}

Na coluna P da Tabela 4.8 têm-se três interações com significância para a Conicidade Vertical. A interação entre Ferramenta Diamantada e Sobremetal, com o menor P_valor da tabela representa a combinação dos fatores que mais interfere no resultado. As interações da Velocidade com o Sobremetal e do Passes com o Sobremetal também são significantes para a característica analisada. A Figura 4.16 contém os gráficos das interações para análise visual.

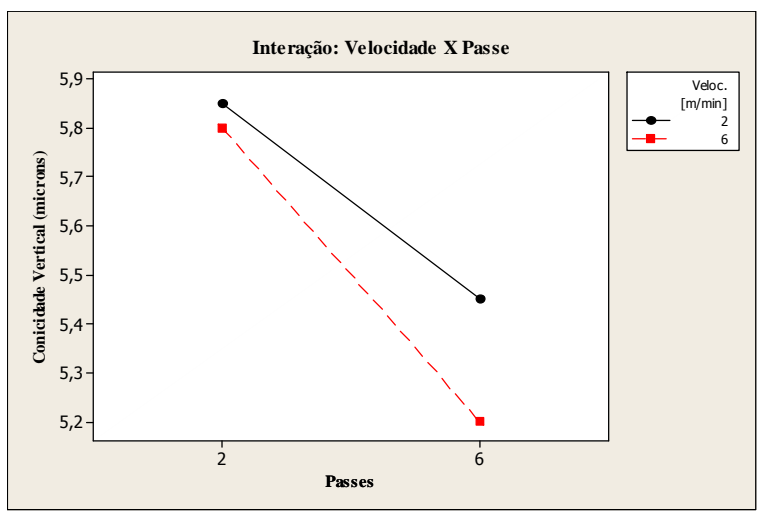

(a) - Velocidade X Passe

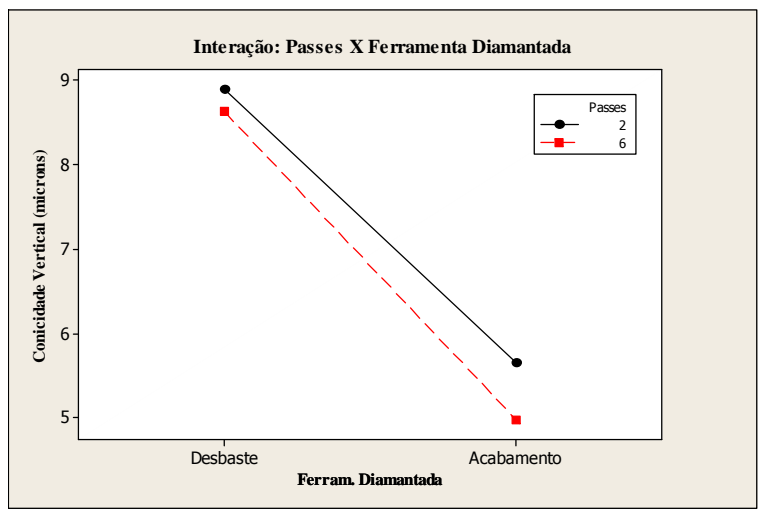

(c) - Passe X Ferramenta Diamantada

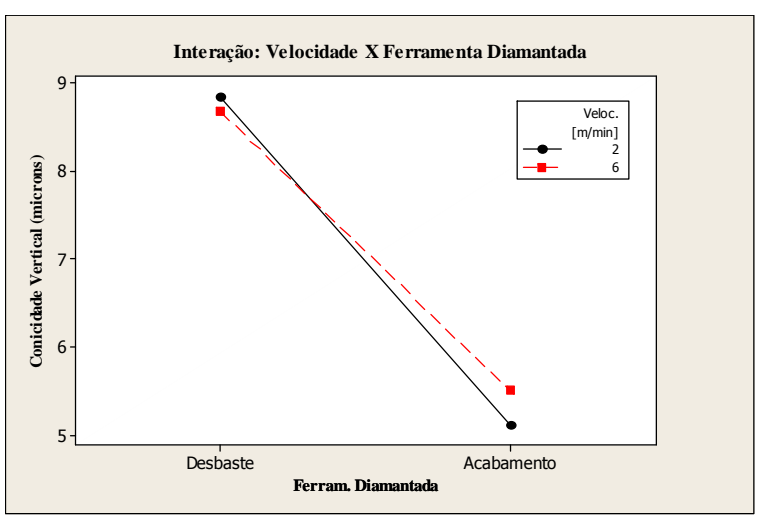

(b) - Velocidade X Ferramenta Diamantada

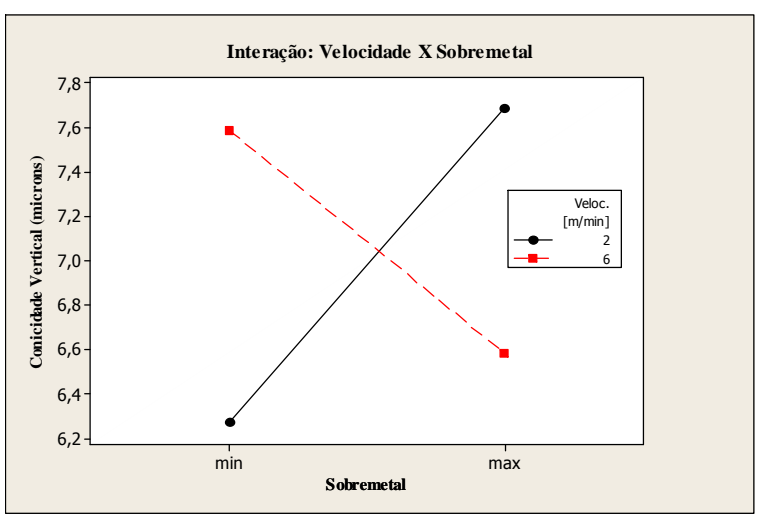

(d) - Velocidade X Sobremetal 


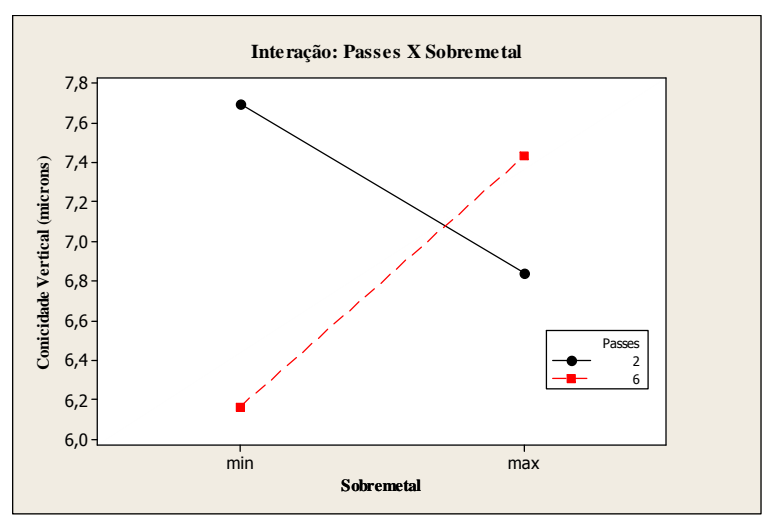

(e) - Passes X Sobremetal

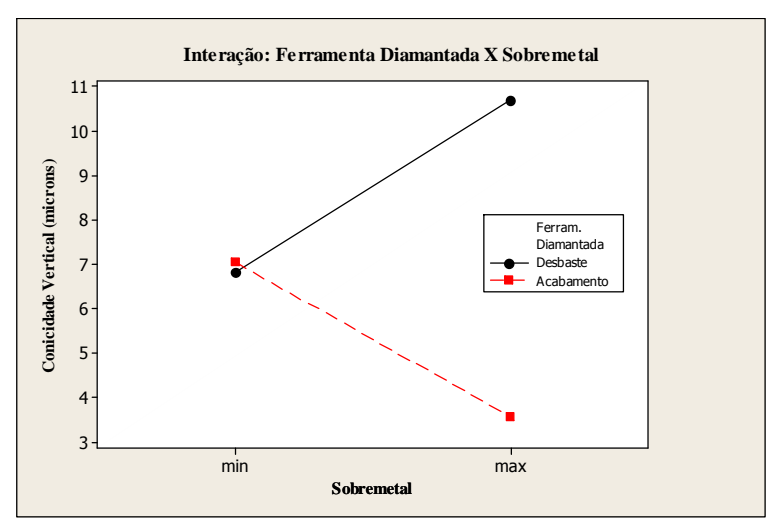

(f) - Ferramenta Diamantada X Sobremetal

Figura 4.16 - Gráfico de interação dos fatores para Conicidade Vertical.

Os gráficos plotados na Figura 4.16 evidenciam a significância das interações conforme o P_valor da Tabela 4.8. As interações que apresentaram P_valor menor que 0,05 estão sendo representadas pelos gráficos (d), (e) e (f) da Figura 4.16, onde ocorre o cruzamento das retas e enfatiza a interferência das combinações no resultado da Conicidade Vertical. Dentre as combinações, a que apresenta o menor P_valor e a maior inclinação das retas é a combinação entre Velocidade de Sobremetal, sendo esta a mais significativa para o resultado.

4.5- Resultados referentes a planicidade da superfície do canal próxima ao furo radial (face $\mathrm{S}$ )

Foi utilizada a ANOVA para determinar o grau de significância das variáveis independente de suas possíveis combinações.

ANOVA para Planicidade S em função de: Velocidade, Passes, Ferramenta Diamantada e Sobremetal.

Tabela 4.9 - Análise ANOVA da Planicidade S com os fatores individuais.

\begin{tabular}{|l|c|c|c|}
\hline Fatores & Tipo & Níveis & Valores \\
\hline Veloc. & fixo & 2 & $2 ; 6$ \\
\hline Ferram. Diamantada & fixo & 2 & Desbaste; Acabamento \\
\hline Sobremetal & fixo & 2 & min; max \\
\hline Passes & fixo & 2 & $2 ; 6$ \\
\hline
\end{tabular}




\begin{tabular}{|l|c|c|c|c|c|}
\hline Fator de controle & $\begin{array}{c}\text { Grau de } \\
\text { liberdade }\end{array}$ & $\begin{array}{c}\text { Soma dos } \\
\text { quadrados }\end{array}$ & $\begin{array}{c}\text { Quadrado } \\
\text { médio }\end{array}$ & Teste F & Valor P \\
\hline Veloc. & 1 & 51,923 & 51,923 & 11,87 & 0,001 \\
\hline Ferram. Diamantada & 1 & 74,517 & 74,517 & 17,04 & 0,000 \\
\hline Sobremetal & 1 & 6,266 & 6,266 & 1,43 & 0,235 \\
\hline Passes & 1 & 19,120 & 19,120 & 4,37 & 0,040 \\
\hline Erro & 75 & 328,072 & 4,374 & & \\
\hline Total & 79 & 479,898 & & & \\
\hline
\end{tabular}

Verificando a coluna $\mathrm{P}$ da análise de variância, tem-se que os fatores Velocidade, Ferramenta Diamantada e Passes, são significantes para o intervalo de confiança de $95 \%$ e, portanto, interferem no resultado da planicidade da superfície do canal. Já com o fator Sobremetal, onde o P_valor é maior que 0,050 , podemos afirmar que esta variável não é significativa para a planicidade nos níveis em que foram realizados os testes.

Na Figura 4.17 estão plotados os gráficos de resíduos para análise da normalidade dos dados.

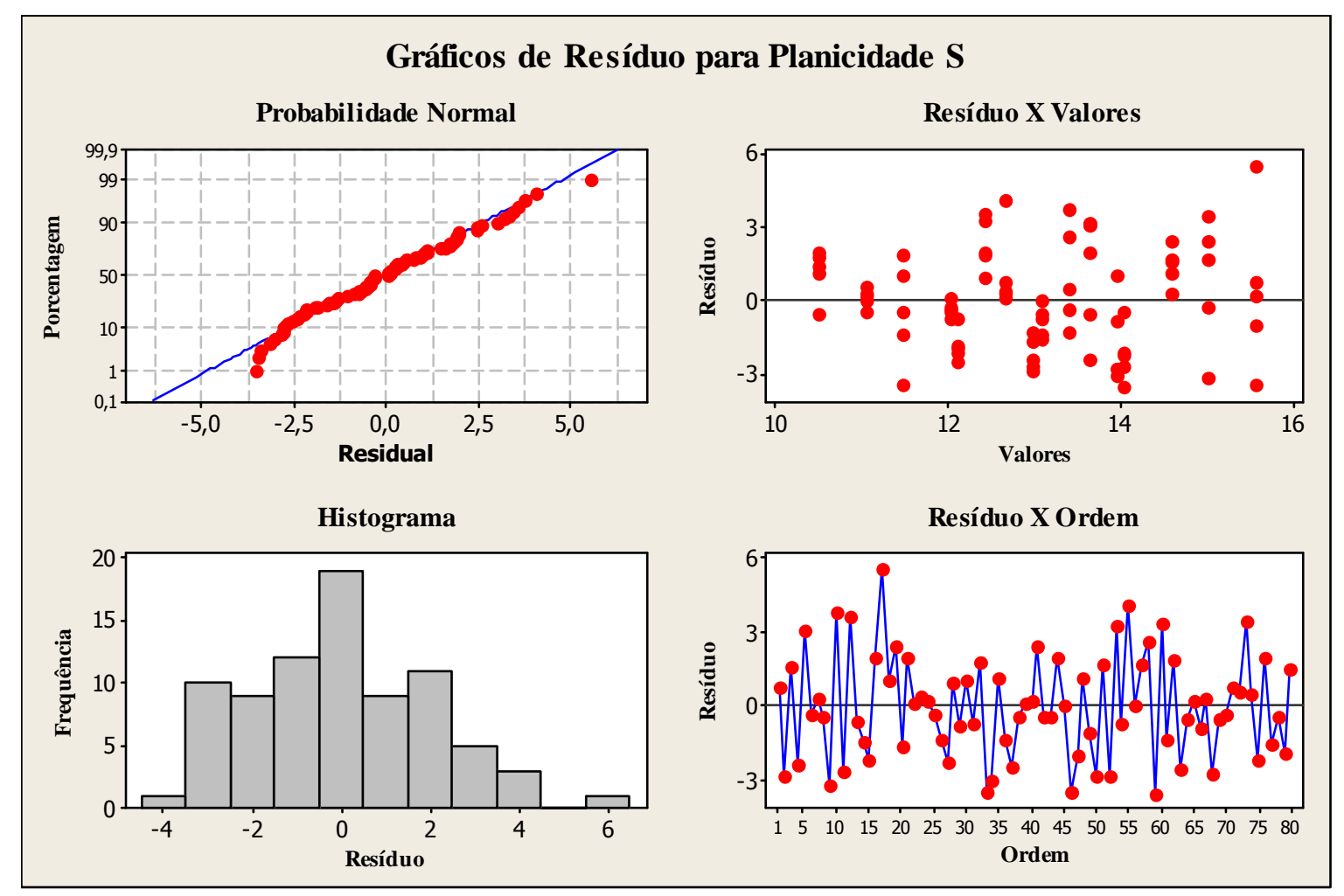

Figura 4.17 - Gráficos de Resíduo para Planicidade S. 
Na Figura 4.17 observamos que no gráfico de Probabilidade Normal os dados dos resíduos estão sobre a reta normal. No gráfico Histograma a distribuição também está próxima de uma normal. O gráfico de Resíduos X Valores apresenta os pontos distribuídos de forma aleatória com leve tendência a se dispersarem com os valores mais altos, próximos do valor 16, mostrando desta forma que o modelo é adequado para os valores mais baixos. $\mathrm{O}$ gráfico Resíduo X Ordem não apresenta tendência e mostra que no decorrer do experimento não ocorreram interferências por alterações do material usinado.

Para a análise individual das variáveis foi utilizado o gráfico de efeitos. O gráfico da Figura 4.18 representa o efeito individual das variáveis.

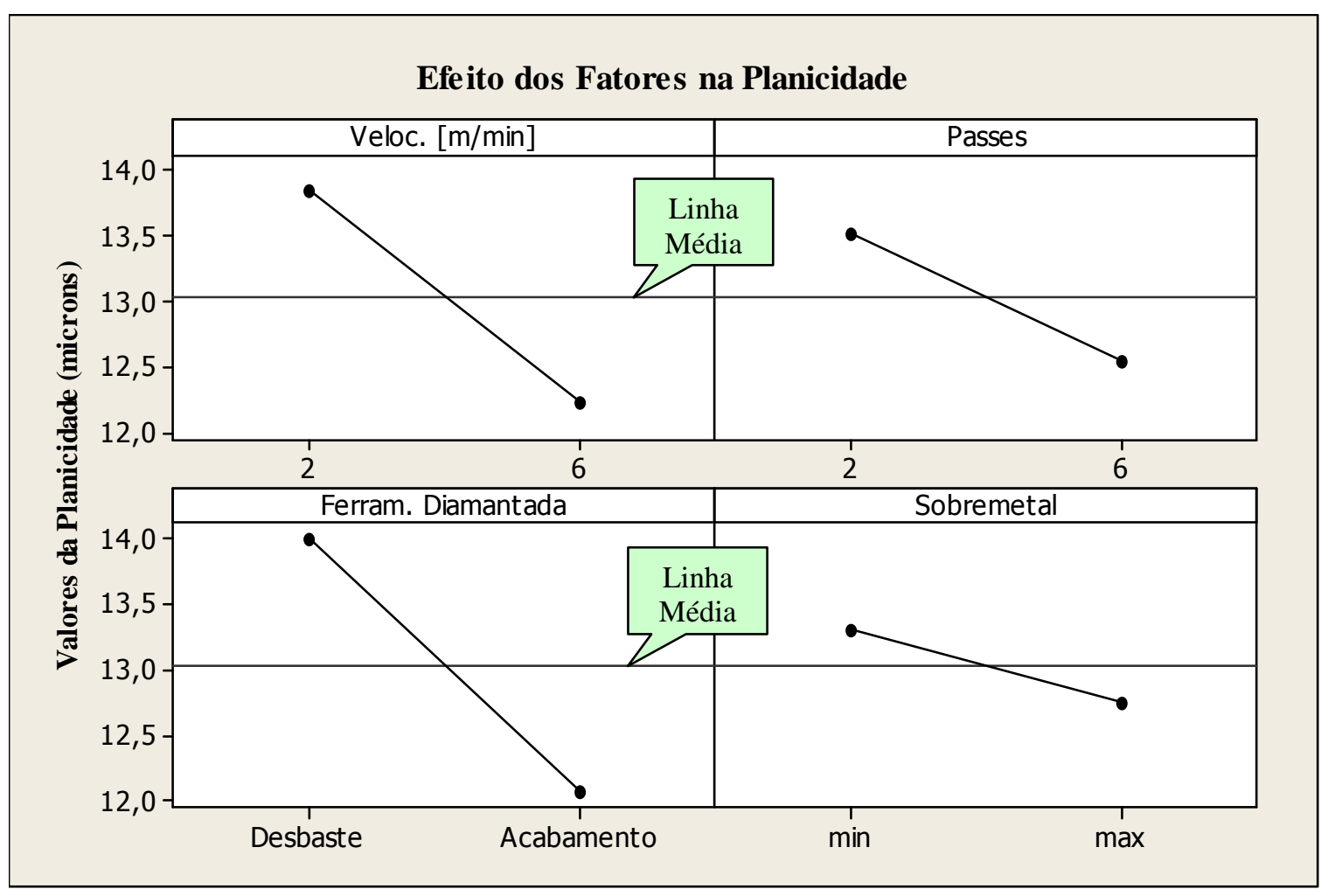

Figura 4.18: Interferência das Variáveis no Processo para Planicidade S.

Para este caso, podemos observar na Figura 4.18 que a Ferramenta Diamantada e a Velocidade apresentam a maior inclinação das retas em relação à linha média dos valores da planicidade, por isto podemos afirmar que individualmente estas duas variáveis interferem no processo de forma mais acentuada que a variável Passes. 
Para analisar a variância de cada uma das quatro variáveis do estudo utilizou-se o “One-Way ANOVA“ também do Minitab, sendo que os resultados estão registrados na Figura 4.19.

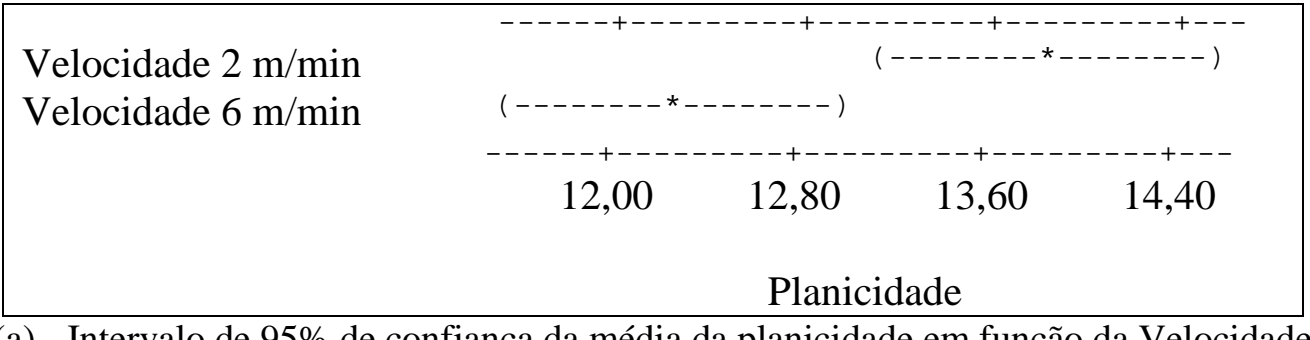

(a) - Intervalo de $95 \%$ de confiança da média da planicidade em função da Velocidade

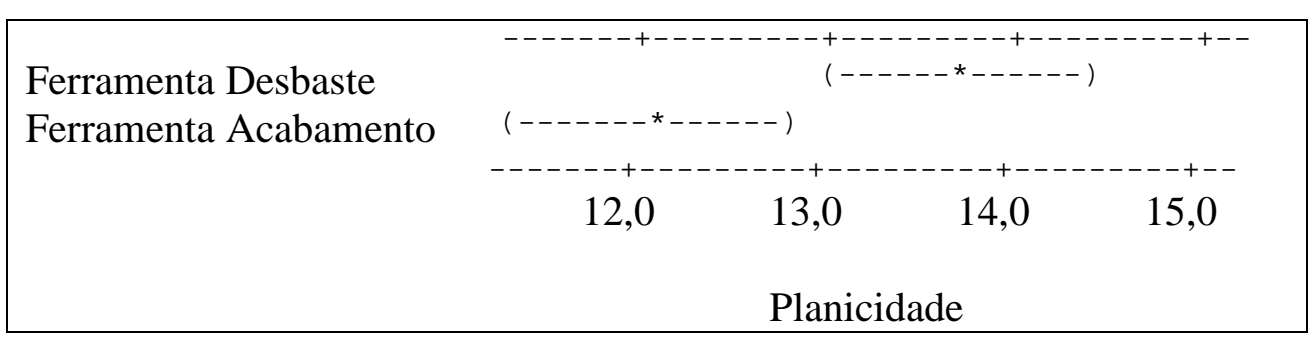

(b) - Intervalo de 95\% de confiança da média da planicidade em função de Ferramenta Diamantada

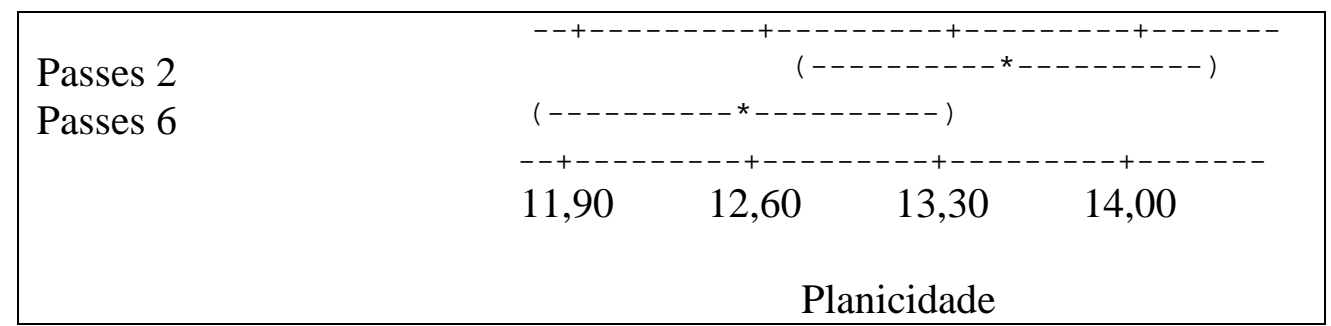

(c) - Intervalo de 95\% de confiança da média da planicidade em função de Passes

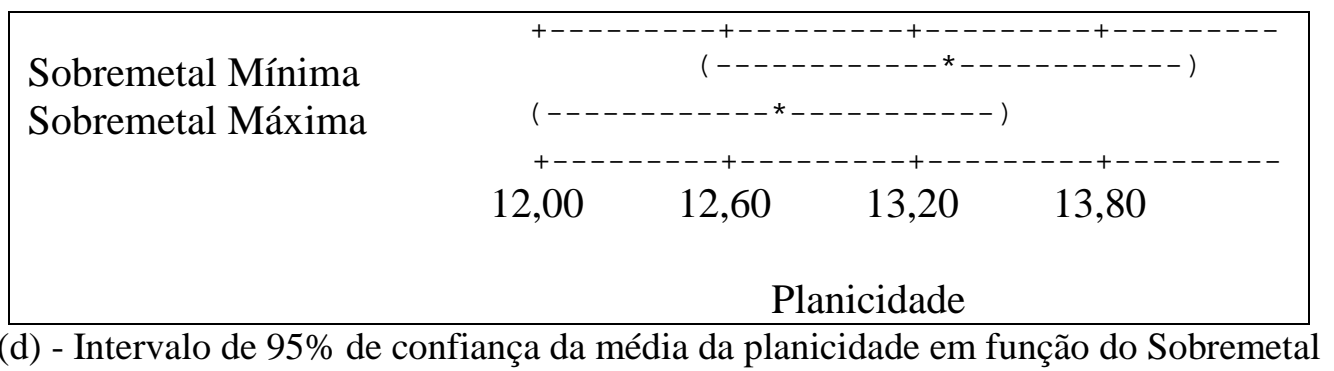

Figura 4.19 - Analise do Intervalo de 95\% de confiança para os quatro fatores para Planicidade S.

Podemos verificar nas Figuras 4.19(c) e 4.19(d) que, para os fatores Passes e Sobremetal, nos dois níveis em que foram analisados, os valores de planicidade encontrados para cada nível se sobrepõem em relação ao outro nível. Esta equivalência dos dados mostra 
que os valores são pouco significativos para esta característica, pois os mesmos valores podem ser encontrados em ambos os níveis. Para as variáveis Velocidade e Ferramenta Diamantada das Figuras 4.19(a) e 4.19(b), onde os valores da Planicidade não apresentam valores comuns entre os dois níveis, pode-se afirmar que individualmente cada uma delas interfere de forma significativa nos resultados para esta característica.

Com a constatação da normalidade dos dados, analisou-se a combinação dos fatores para determinar se as combinações destes apresentam alterações na Planicidade, ou seja, se as interações apresentam significância para o estudo. A Tabela 4.10 mostra a interação dos fatores.

Tabela 4.10 - Análise ANOVA da Planicidade S com os fatores combinados dois a dois.

\begin{tabular}{|l|c|c|c|c|c|}
\hline Fator de controle & $\begin{array}{c}\text { Grau de } \\
\text { liberdade }\end{array}$ & $\begin{array}{c}\text { Soma dos } \\
\text { quadrados }\end{array}$ & $\begin{array}{c}\text { Quadrado } \\
\text { médio }\end{array}$ & $\begin{array}{c}\text { Teste } \\
\text { F }\end{array}$ & Valor P \\
\hline Veloc. & 1 & 51,923 & 51,923 & 17,02 & 0,000 \\
\hline Passes & 1 & 19,120 & 19,120 & 6,27 & 0,015 \\
\hline Ferram. Diamantada & 1 & 74,517 & 74,517 & 24,43 & 0,000 \\
\hline Sobremetal & 1 & 6,266 & 6,266 & 2,05 & 0,156 \\
\hline Veloc. *Passes & 1 & 10,738 & 10,738 & 3,52 & 0,065 \\
\hline Veloc. *Ferram. Diamantada & 1 & 1,233 & 1,233 & 0,40 & 0,527 \\
\hline Veloc. *Sobremetal & 1 & 82,398 & 82,398 & 27,01 & 0,000 \\
\hline Passes *Ferram. Diamantada & 1 & 1,738 & 1,738 & 0,57 & 0,453 \\
\hline Passes *Sobremetal & 1 & 1,455 & 1,455 & 0,48 & 0,492 \\
\hline Ferram. Diamantada *Sobremetal & 1 & 20,050 & 20,050 & 6,57 & 0,013 \\
\hline Erro & 69 & 210,460 & 3,050 & & \\
\hline Total & 79 & 479,898 & & & \\
\hline
\end{tabular}

De acordo com a Tabela 4.10, a coluna $\mathrm{P}$ que apresenta o valor de 0,000 para a interação entre a Velocidade e o Sobremetal determina a significância desta interação para os resultados da Planicidade S. A Figura 4.20 mostra os resultados em forma de gráficos. 


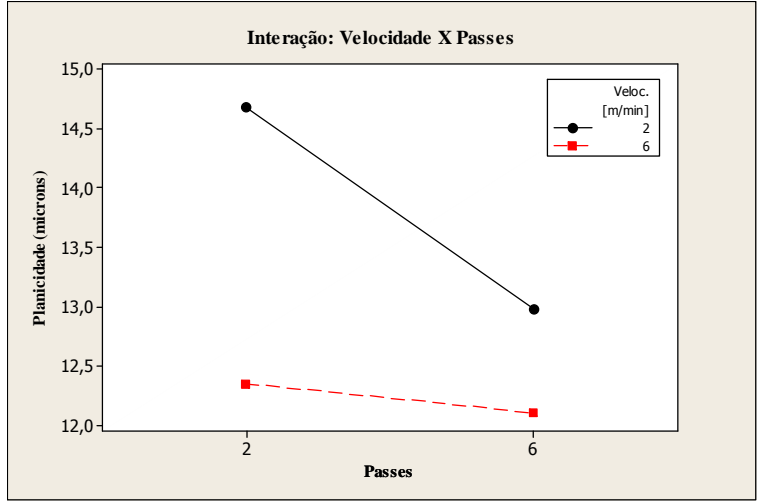

(a) - Velocidade X Passe

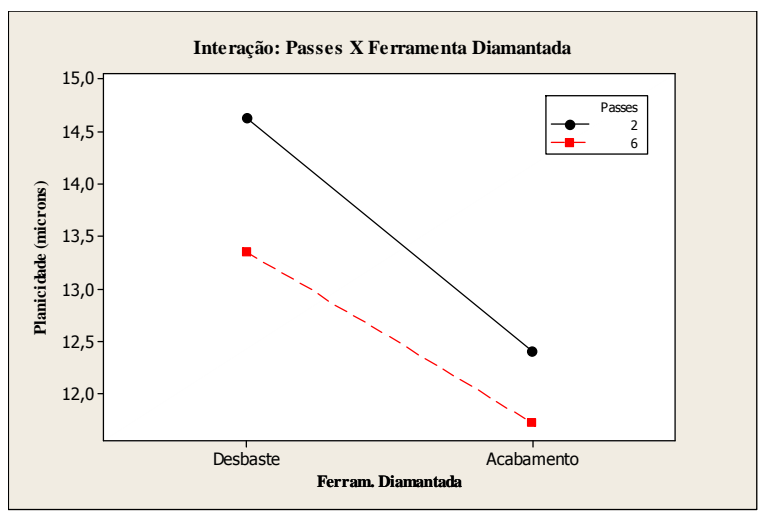

(c) - Passe X Ferramenta Diamantada

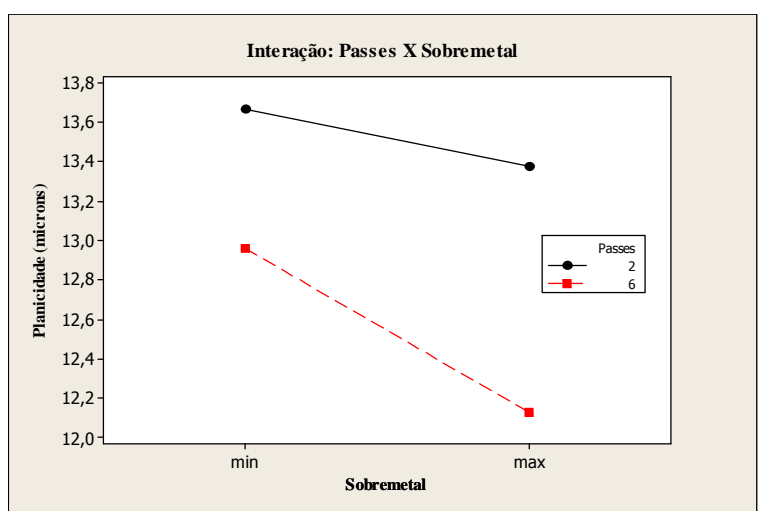

(e) - Passes X Sobremetal

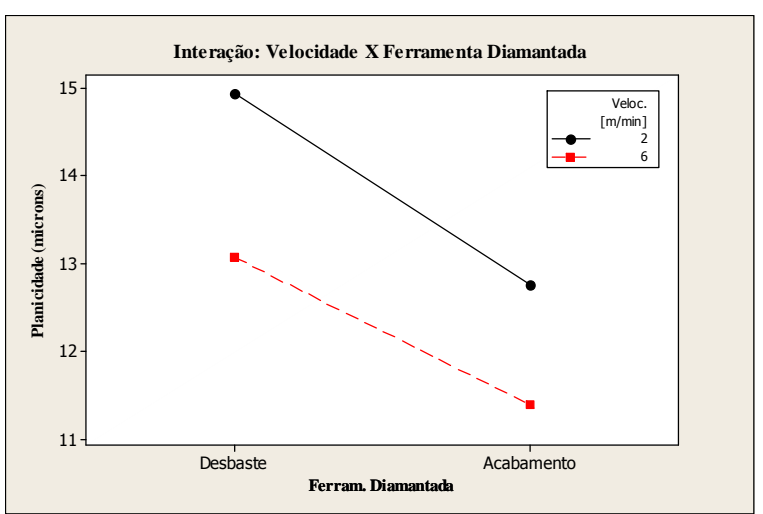

(b) - Velocidade X Ferramenta Diamantada

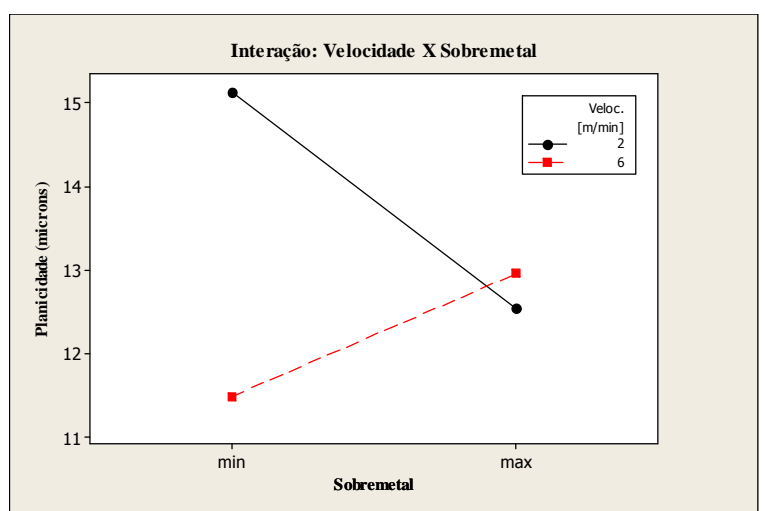

(d) - Velocidade X Sobremetal

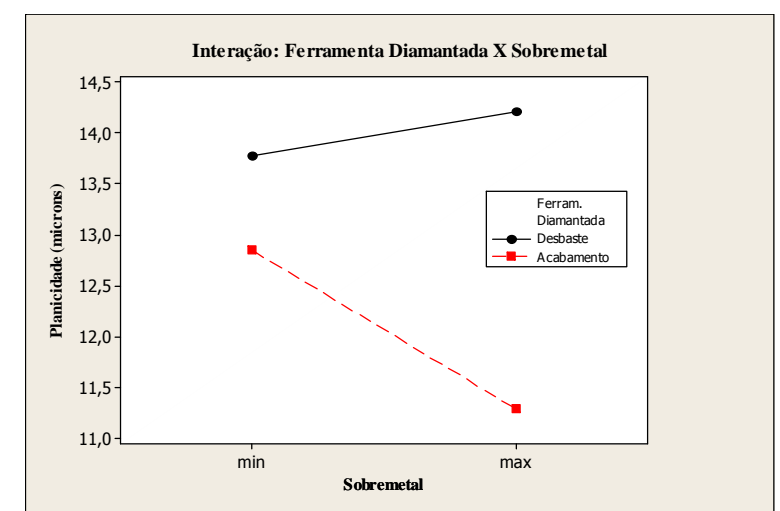

(f) - Ferramenta Diamantada X Sobremetal

Figura 4.20 - Gráfico de interação dos fatores para Planicidade S.

Os gráficos plotados na Figura 4.20 demonstram que a maior interação está entre a Velocidade e o Sobremetal vista na Figura 4.20(d), sendo que esta interação apresenta significância para a Planicidade S no intervalo estudado. Além do P_valor da Tabela 4.10 vemos no gráfico que existe o cruzamento das retas, fato este que comprova sua significância. 
A interação Ferramenta Diamantada e Sobremetal que apresentou P_valor de 0,013 também é significante para os resultados. As retas do gráfico não se cruzam, mas existe uma inclinação acentuada entre elas, conforme Figura 4.2(f).

$\underline{\text { 4.5- Resultados referentes a planicidade da superfície do canal na face oposta ao furo radial }}$ $\underline{(\text { face } A)}$

Foi utilizada a ANOVA para determinar o grau de significância das variáveis independente de suas possíveis combinações.

ANOVA para Planicidade A em função de: Velocidade, Passes, Ferramenta Diamantada e Sobremetal.

Tabela 4.11 - Análise ANOVA da Planicidade A com os fatores individuais.

\begin{tabular}{|l|c|c|c|}
\hline Fatores & Tipo & Níveis & Valores \\
\hline Veloc. & fixo & 2 & $2 ; 6$ \\
\hline Ferram. Diamantada & fixo & 2 & Desbaste; Acabamento \\
\hline Sobremetal & fixo & 2 & min; max \\
\hline Passes & fixo & 2 & $2 ; 6$ \\
\hline
\end{tabular}

\begin{tabular}{|l|c|c|c|c|c|}
\hline Fator de controle & $\begin{array}{c}\text { Grau de } \\
\text { liberdade }\end{array}$ & $\begin{array}{c}\text { Soma dos } \\
\text { quadrados }\end{array}$ & $\begin{array}{c}\text { Quadrado } \\
\text { médio }\end{array}$ & Teste F & Valor P \\
\hline Veloc. & 1 & 59,530 & 59,530 & 14,29 & 0,000 \\
\hline Ferram. Diamantada & 1 & 29,805 & 29,805 & 7,15 & 0,000 \\
\hline Sobremetal & 1 & 82,845 & 82,845 & 19,89 & 0,009 \\
\hline Passes & 1 & 13,753 & 13,753 & 3,30 & 0,073 \\
\hline Erro & 75 & 312,437 & 4,166 & & \\
\hline Total & 79 & 498,369 & & & \\
\hline
\end{tabular}

Verificando a coluna $\mathrm{P}$ da análise de variância, tem-se que os fatores Velocidade, Ferramenta Diamantada e Sobremetal são significantes para o intervalo de confiança de 95\% e, portanto, interferem no resultado da Planicidade A da superfície do canal. Já com o fator Passes, onde o P_valor é maior que 0,050, podemos afirmar que esta variável não é significativa para a planicidade nos níveis em que foram realizados os testes. 
Na Figura 4.21 estão plotados os gráficos de resíduos para análise da normalidade dos dados.

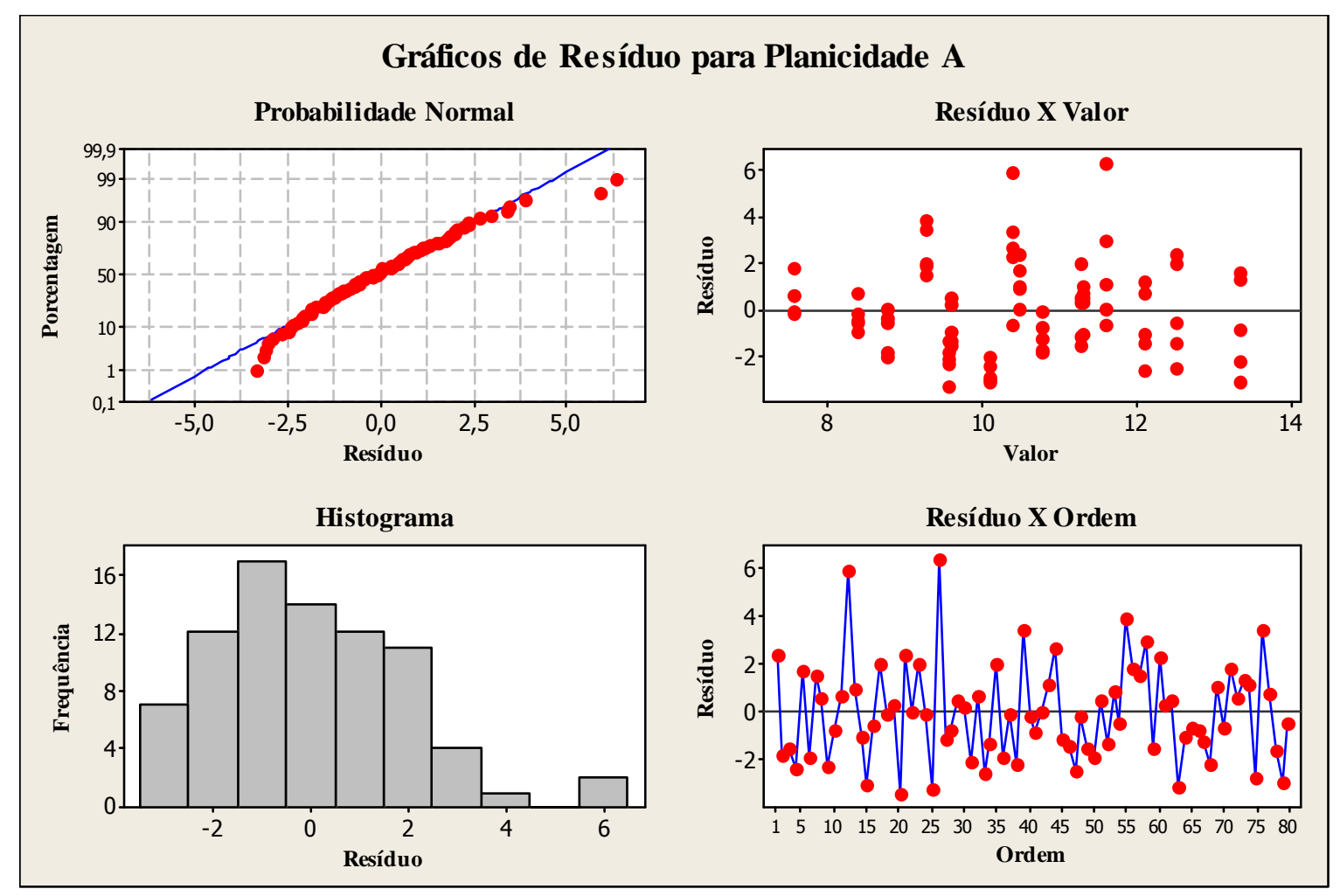

Figura 4.21 - Gráficos de resíduos para Planicidade A .

Na Figura 4.21 observamos que no gráfico de Probabilidade Normal os dados dos resíduos estão sobre a reta normal. No gráfico Histograma a distribuição também está próxima de uma normal. O gráfico de Resíduos X Valores apresenta os pontos distribuídos de forma aleatória com leve dispersão dos valores na região central do gráfico, entre os valores de 10 e $12 \mu \mathrm{m}$ de planicidade. O gráfico Resíduo X Ordem não apresenta tendência e também mostra que no decorrer do experimento não ocorreram interferências externas como por exemplo alterações do material usinado.

Para a análise individual das variáveis, foi utilizado o gráfico de efeitos. Esta análise que é feita considerando a inclinação da reta em relação à linha média dos valores da Planicidade A pode ser observada na Figura 4.22. 


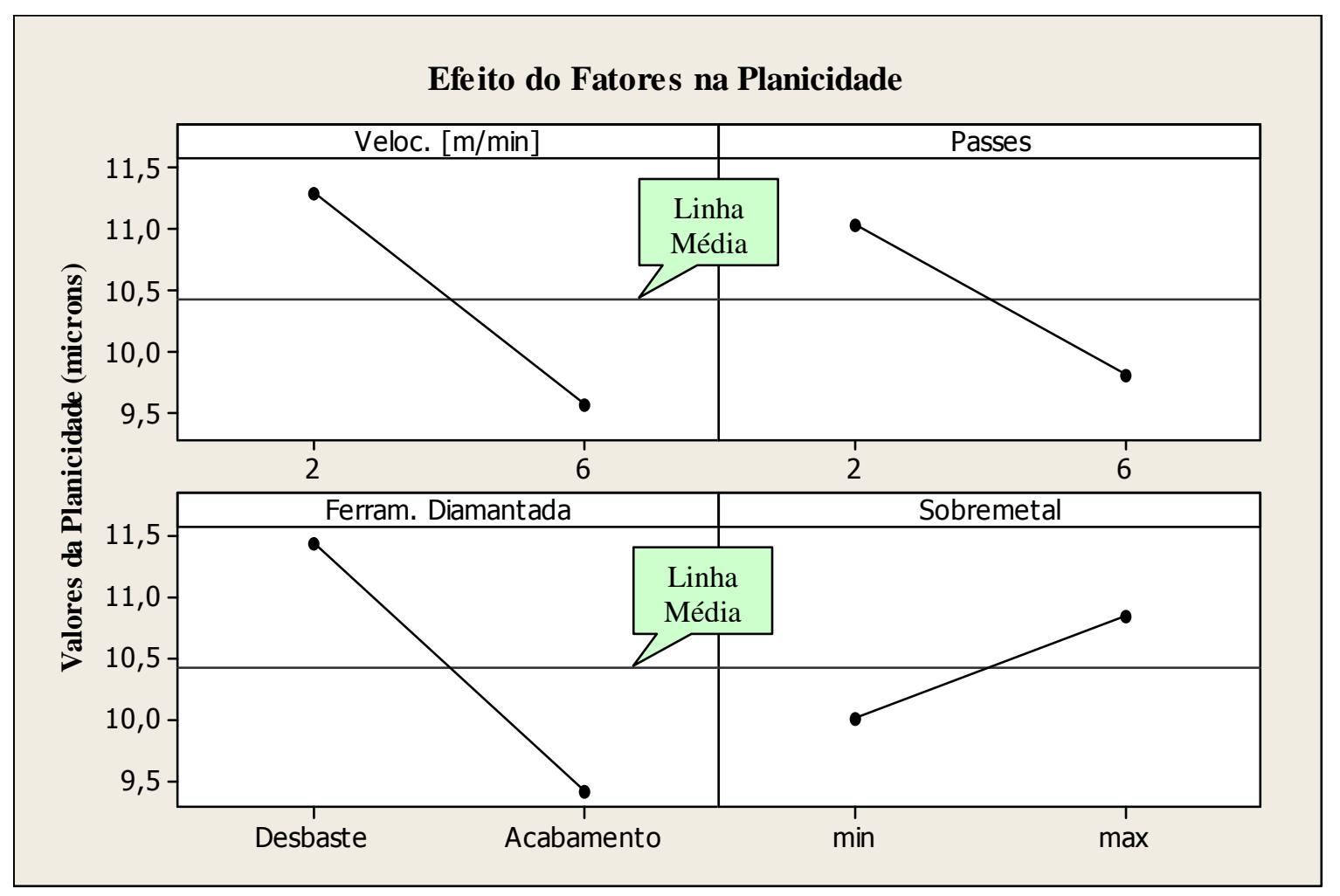

Figura 4.22 - Interferência das Variáveis no Processo para Planicidade A.

Para este caso, podemos observar na Figura 4.22 que a Ferramenta Diamantada e a Velocidade apresentam a maior inclinação das retas em relação à linha média dos valores da planicidade, por isto podemos afirmar que individualmente estas duas variáveis interferem no processo de forma mais acentuada que as outras duas variáveis Passes e Sobremetal.

Para analisar a variância de cada uma das quatro variáveis do estudo utilizou-se o “One-Way ANOVA“ também do Minitab e os resultados estão registrados na Figura 4.23.

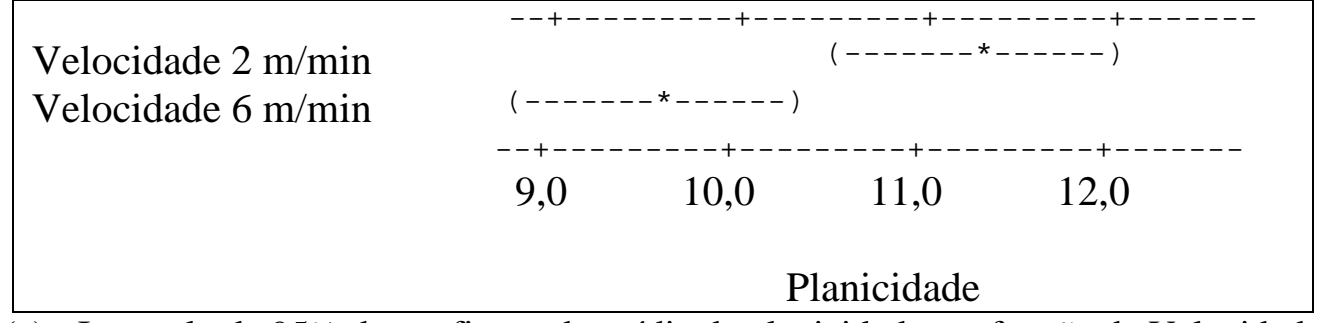

(a) - Intervalo de $95 \%$ de confiança da média da planicidade em função da Velocidade 
Ferramenta Desbaste Ferramenta Acabamento

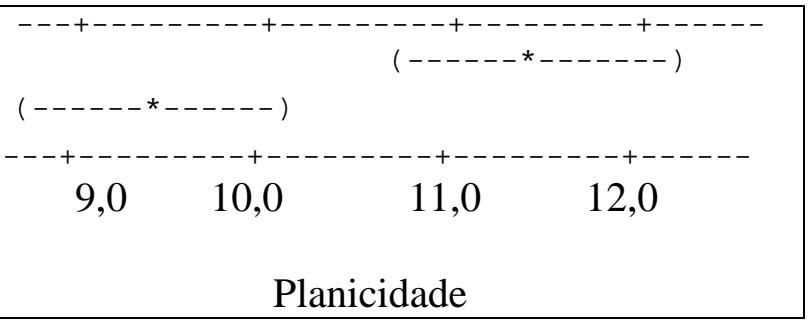

(b) - Intervalo de 95\% de confiança da média da planicidade em função de Ferramenta Diamantada.

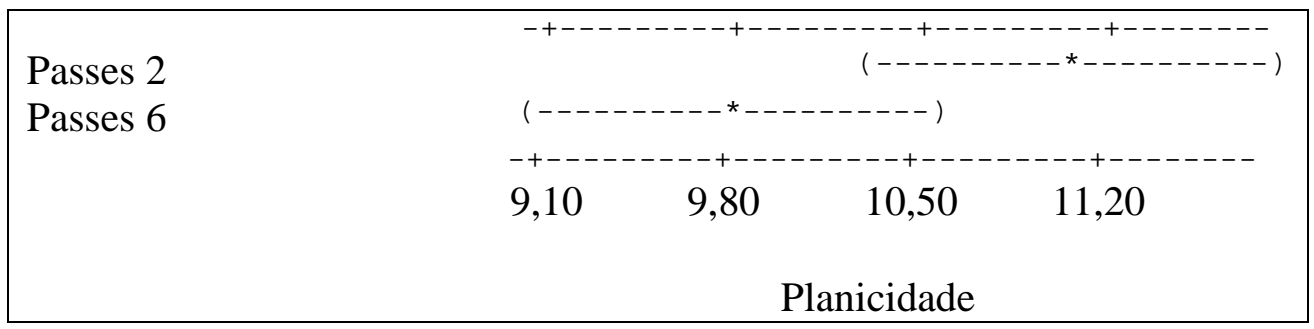

(c) - Intervalo de 95\% de confiança da média da planicidade em função de Passes.

Sobremetal Mínima

Sobremetal Máxima

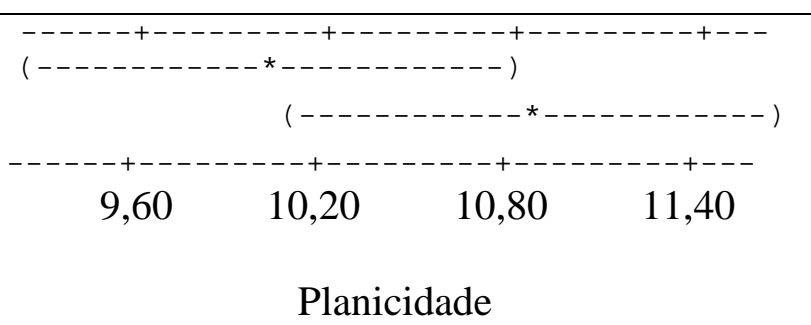

Planicidade

(d) - Intervalo de 95\% de confiança da média da planicidade em função do Sobremetal.

Figura 4.23 - Análise do Intervalo de 95\% de confiança para os quatro fatores para Planicidade A.

Podemos verificar nas Figuras 4.23(c) e 4.23(d) que para os fatores Passes e Sobremetal nos dois níveis em que foram analisados, os valores de Planicidade A encontrados para cada nível se sobrepõem em relação ao outro nível. Esta equivalência dos dados mostra que os valores são pouco significativos para esta característica, pois os mesmos valores podem ser encontrados em ambos os níveis.

Para as variáveis Velocidade e Ferramenta Diamantada das Figuras 4.23(a) e 4.23(b), onde os valores da Planicidade A não apresentam valores comuns entre os dois níveis, podese afirmar que individualmente cada uma delas interfere de forma significativa nos resultados para esta característica. A inclinação das retas na Figura 4.22 confirmam os resultados.

Com a constatação da normalidade dos dados, analisou-se a combinação dos fatores para determinar se as combinações destes apresentam alterações na Planicidade A, ou seja, se 
as interações apresentam significância para o estudo. A Tabela 4.12 mostra a interação entre os fatores.

Tabela 4.12 - Análise ANOVA da Planicidade A com os fatores combinados dois a dois.

\begin{tabular}{|l|c|c|c|c|c|}
\hline Fator de controle & $\begin{array}{c}\text { Grau de } \\
\text { liberdade }\end{array}$ & $\begin{array}{c}\text { Soma dos } \\
\text { quadrados }\end{array}$ & $\begin{array}{c}\text { Quadrado } \\
\text { médio }\end{array}$ & $\begin{array}{c}\text { Teste } \\
\mathrm{F}\end{array}$ & $\begin{array}{c}\text { Valor } \\
\mathrm{P}\end{array}$ \\
\hline Veloc. & 1 & 59,530 & 59,530 & 24,25 & 0,000 \\
\hline Passes & 1 & 29,805 & 29,805 & 12,14 & 0,001 \\
\hline Ferram. Diamantada & 1 & 82,845 & 82,845 & 33,74 & 0,000 \\
\hline Sobremetal & 1 & 13,753 & 13,753 & 5,60 & 0,021 \\
\hline Veloc. *Passes & 1 & 3,062 & 3,062 & 1,25 & 0,268 \\
\hline Veloc. *Ferram. Diamantada & 1 & 9,119 & 9,119 & 3,71 & 0,058 \\
\hline Veloc. *Sobremetal & 1 & 70,632 & 70,632 & 28,77 & 0,000 \\
\hline Passes *Ferram. Diamantada & 1 & 0,080 & 0,080 & 0,03 & 0,857 \\
\hline Passes *Sobremetal & 1 & 4,385 & 4,385 & 1,79 & 0,186 \\
\hline Ferram. Diamantada *Sobremetal & 1 & 55,761 & 55,761 & 22,71 & 0,000 \\
\hline Erro & 69 & 169,398 & 2,455 & & \\
\hline Total & 79 & 498,369 & & & \\
\hline
\end{tabular}

Na coluna $\mathrm{P}$ da Tabela 4.12 observam-se duas interações significativas para a Planicidade A, que são as interações entre Velocidade e Sobremetal e também entre Ferramenta Diamantada e Sobremetal. Embora o fator Passes tenha apresentado significância na análise isolada, em nenhuma das interações com os outros fatores que também são significantes foi constatada a interação. A Figura 4.24 ilustra os resultados.

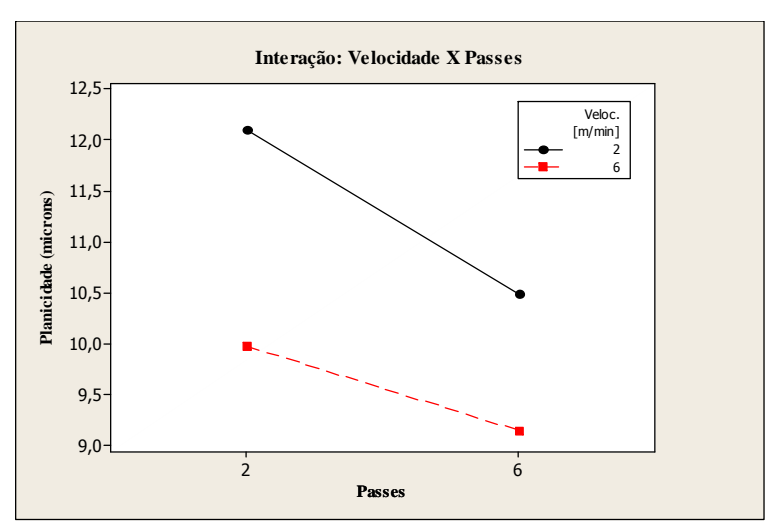

(a) - Velocidade X Passes

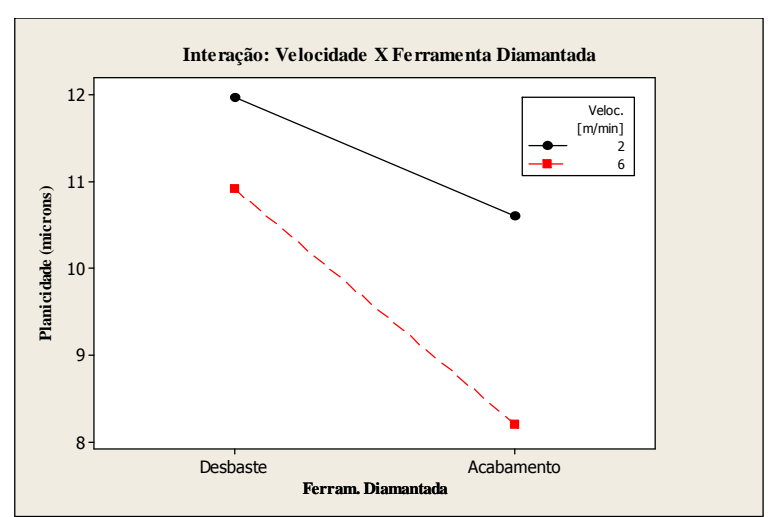

(b) - Velocidade X Ferramenta Diamantada 


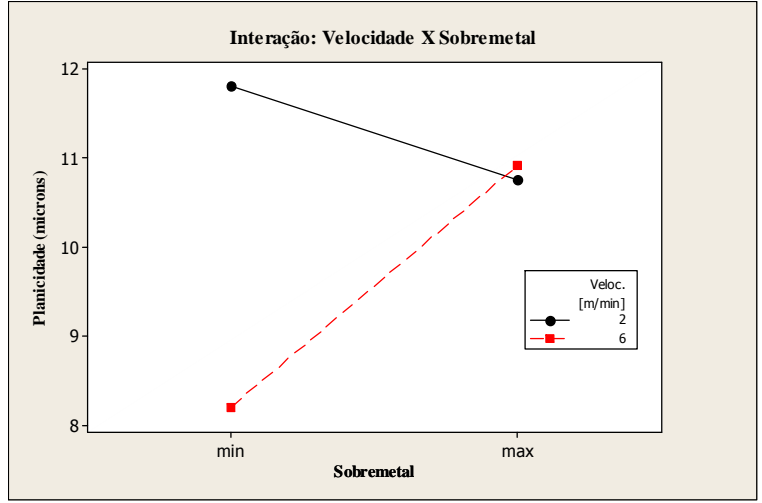

(c) - Velocidade X Sobremetal

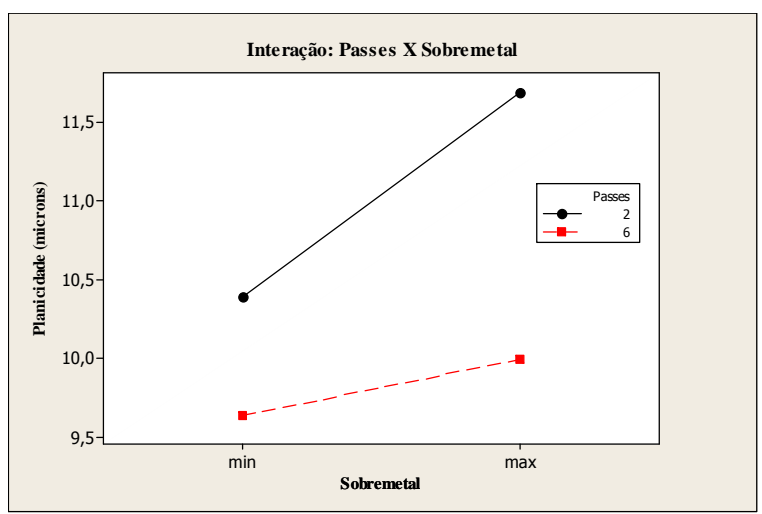

(e) - Passes X Sobremetal

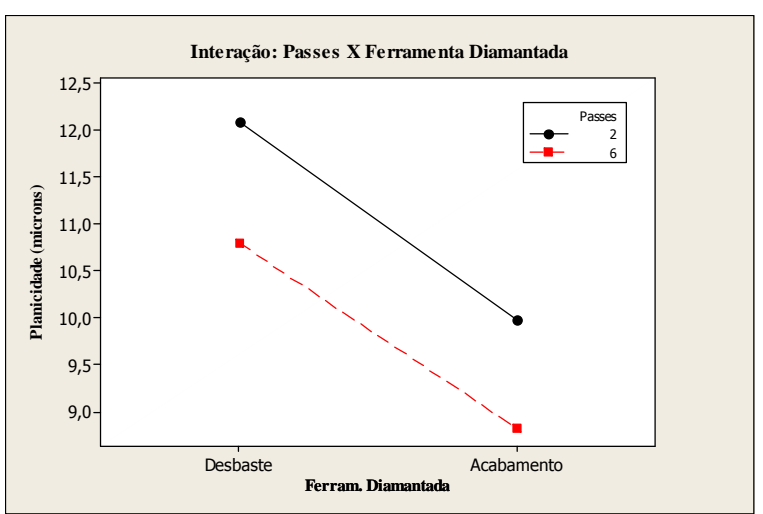

(d) - Passes X Ferramenta Diamantada

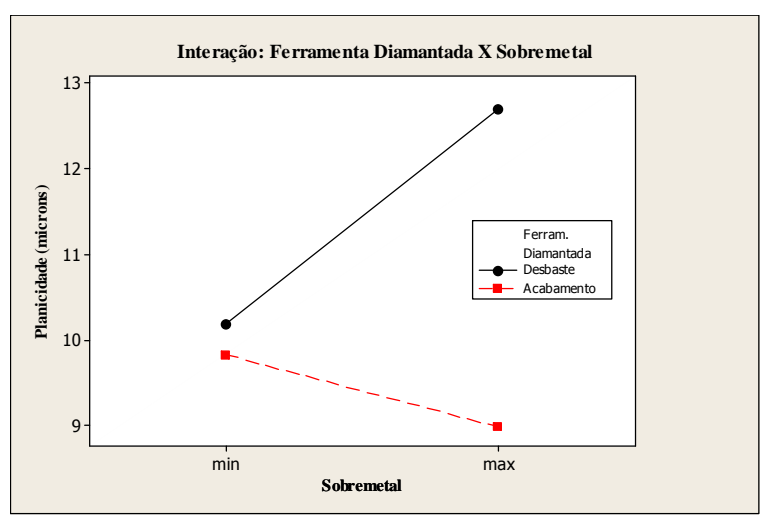

(f) - Ferramenta Diamantada X Sobremetal

Figura 4.24: Gráfico de interação dos fatores para Planicidade A

Os gráficos plotados na Figura 4.24 itens (c) e (f) apresentam as maiores inclinações entre as retas e confirmam a significância das interações demonstradas com o P_valor menor que 0,050 na Tabela 4.12 .

\section{$\underline{\text { 4.7- Análise comparativa entre Planicidade A e Planicidade S }}$}

Os valores obtidos com a medição da planicidade das duas faces do canal permitem observar uma diferença entre suas médias. A superfície da face em que se encontra uma furação próxima ao canal possui um maior erro de planicidade, sendo que este fato pode estar relacionado com a formação de uma parede delgada definida entre a furação radial e o próprio canal. Em virtude desta hipótese foram feitas duas análises comparativas entre as superfícies das duas faces do canal: 
Para a comparação das planicidades foi plotado o gráfico de intervalo com as médias das planicidade S e A conforme Figura 4.25.

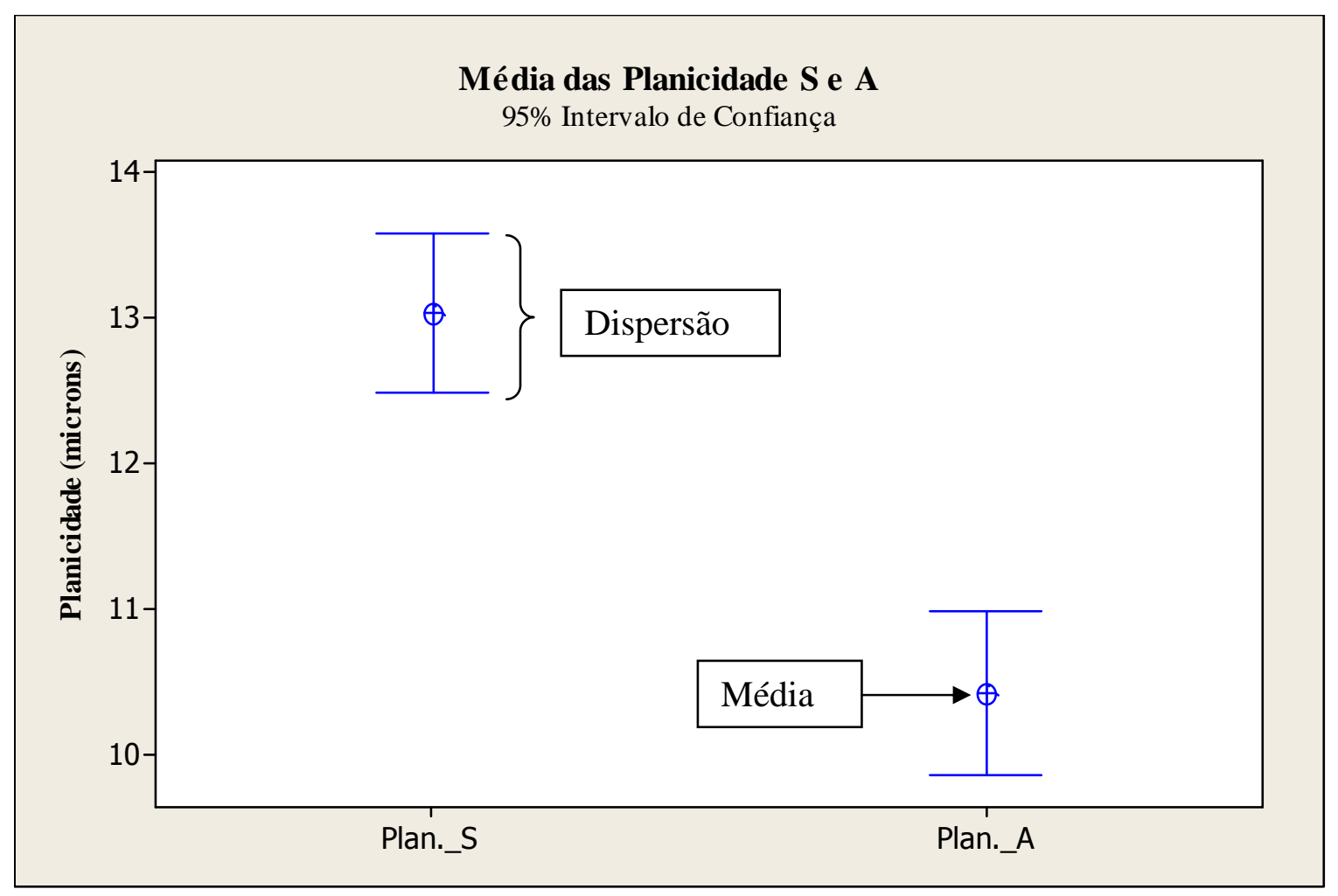

Figura 4.25 - Comparação da média e da dispersão das planicidades S e A

No gráfico da Figura 4.25 pode ser verificado que embora as dispersões sejam semelhantes, o valor médio da planicidade da face $\mathrm{S}$ é maior que o valor médio da Planicidade A, ou seja, a Planicidade S apresenta um maior erro, que supostamente é determinado pela deformação elástica da parede da face durante o brochamento.

A furação radial determina uma região delgada entre a face da superfície e o próprio furo, podendo gerar um maior erro de planicidade. A Figura 4.26 mostra um exemplo da planicidade de uma peça onde foi constatada esta deformação. 


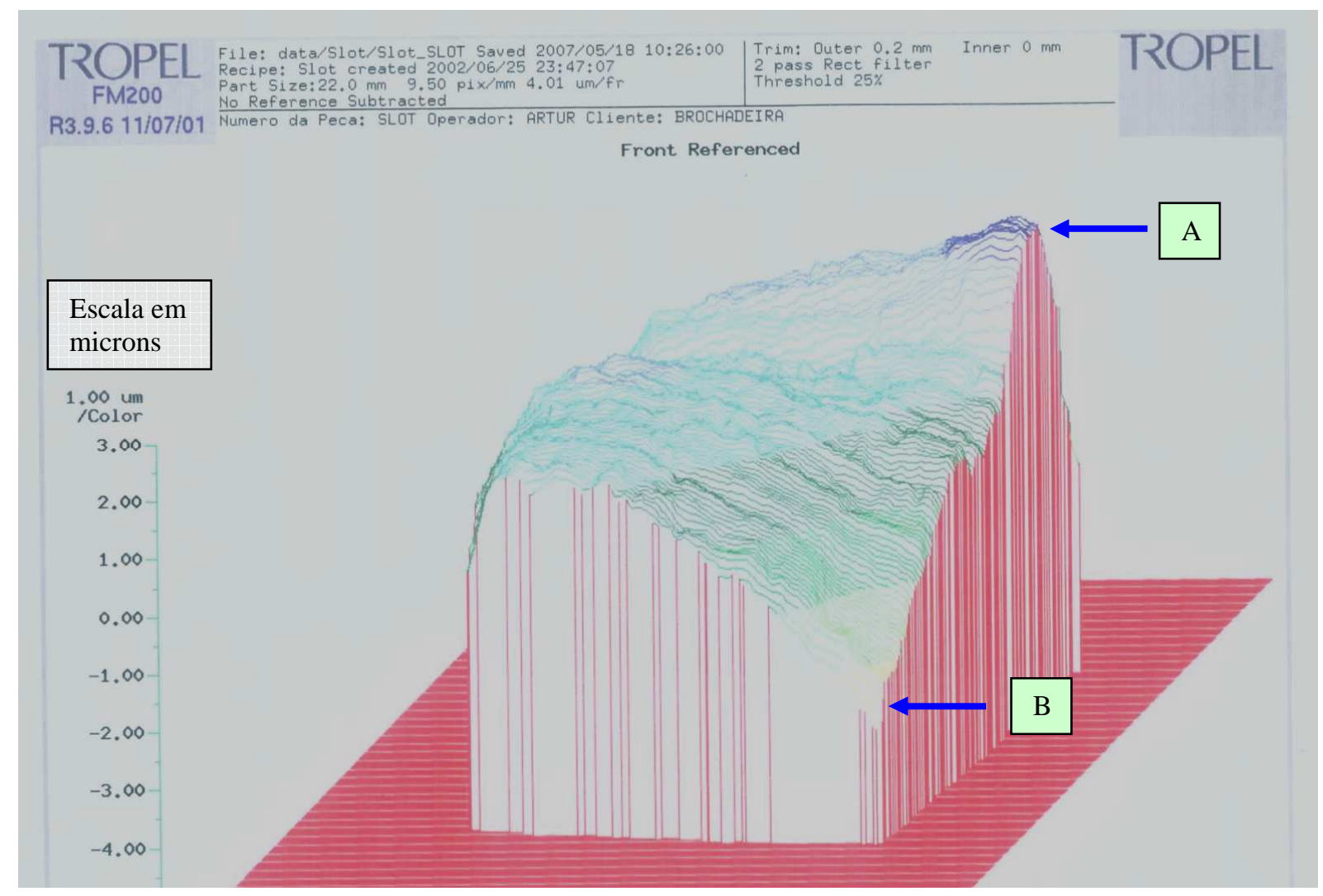

Figura 4.26 - Representação da planicidade da face do canal com a indicação da região próxima ao furo radial.

A Figura 4.26 representa a planicidade de uma das peças medidas no Tropel. O relevo da superfície indica as diferenças de alturas entre os pontos medidos na face da peça. A seta "B" está indicando o ponto mais baixo da face da peça e a seta "A" está indicando o ponto mais alto encontrado na medição. A escala lateral está indicando as faixas de altura em microns.

A diferença entre o ponto mais alto e o ponto mais baixo determina o maior erro de planicidade encontrado na peça. O ponto mais alto da planicidade está próximo da região em que existe a furação radial, e este fato pode estar determinando um maior erro da planicidade. Para verificar a interferência desta variável, realizou-se uma análise de correlação entre a espessura da parede e a planicidade de cada peça.

Teste de correlação realizado no Minitab para verificar uma possível interferência da espessura da parede no valor da planicidade: 
Correlação entre espessura e planicidade $=-0,454$

$\mathrm{P}-$ Valor $=0,001$

P_valor $<$ 0,05 demonstra que existe correlação entre a espessura e a planicidade.

Correlação com valor negativo mostra que existe uma relação inversa entre a planicidade e a espessura. Por esta análise, podemos identificar que uma maior espessura da parede pode determinar um menor erro de planicidade da face brochada.

Diante da constatação de uma pequena correlação, foi feita uma regressão linear e a mesma apresentou um $\mathrm{R}^{2}(\mathrm{R}-\mathrm{Sq}=20,6 \%)$ muito baixo, conforme o gráfico da Figura 4.27.

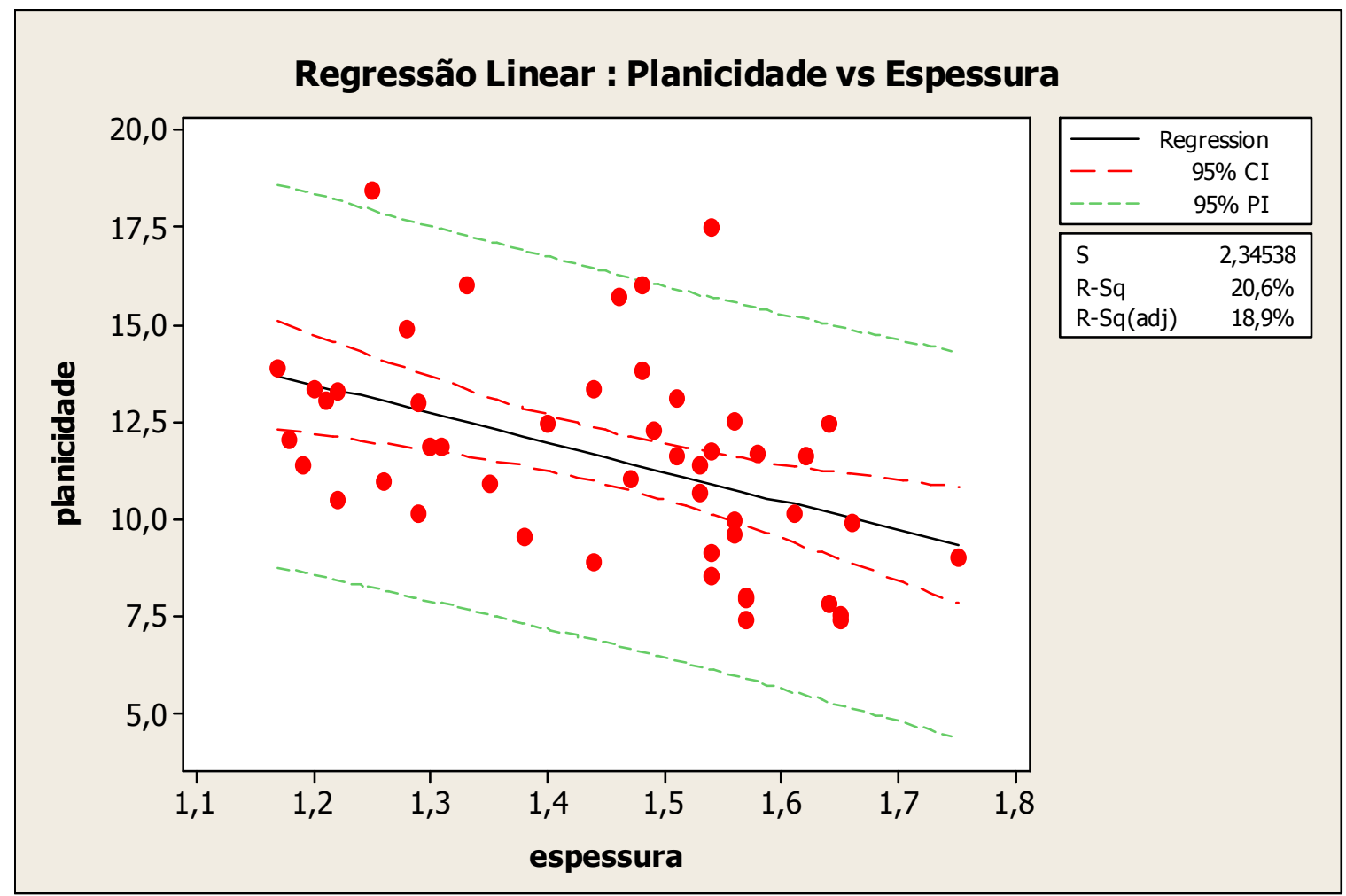

Figura 4.27 - Regressão Linear entre a Planicidade S e a espessura da parede.

A Figura 4.27 mostra que os dados estão bastante dispersos e apenas $20,6 \%$ dos pontos estão dentro de $95 \%$ do Intervalo de Confiança, fato este que impede o equacionamento 
matemático para esta relação. No entanto, pela curva do gráfico da Figura 4.27 percebe-se que existe uma tendência de que o erro da planicidade seja menor para maiores espessuras da parede. 


\section{5- Conclusões e Sugestões para Futuros Trabalhos}

O experimento realizado com o brochamento em operação de acabamento teve como objetivo identificar alguns dos parâmetros da usinagem que apresentam maior interferência. As análises foram feitas considerando a qualidade geométrica e superficial das peças. Os resultados mostraram que:

- A Rugosidade Ra sofre interferência dos fatores Ferramenta Diamantada e Sobremetal, isto ocorre de forma isolada com cada um destes fatores e também na combinação de ambos;

- O perpendicularismo do canal sofre influência dos fatores Velocidade, Passes e Sobremetal quando analisados sem as interações, no entanto apenas a combinação da Velocidade com o Sobremetal apresenta significância para esta característica;

- A Conicidade Horizontal tem seus valores influenciados pela Ferramenta Diamantada quando considerado este fator sem interações com os demais. A interação deste com o Sobremetal também apresenta significância, no entanto a combinação de dois fatores que isoladamente não apresentam significância pode interferir nos resultados, este fato pode ser confirmado com a interação entre Passes e Sobremetal, que neste caso apresentou interferência na Conicidade Horizontal;

- A Conicidade Vertical apresentou sofrer influência direta apenas para o fator Ferramenta Diamantada, embora o Sobremetal não tenha interferido nos resultados para esta característica, todas as interações deste fator apresentam interferência nos resultado;

- A planicidade de ambas as faces do canal sofrem maior interferência dos fatores isoladamente, somente as combinações entre os fatores Velocidade * Sobremetal e Ferramenta Diamantada * Sobremetal determinam variações nos resultados desta característica. 
O trabalho mostrou que os quatro fatores podem interferir de forma significativa na qualidade superficial e geométrica das faces do canal usinado em operação de brochamento, no entanto as características podem sofrer interferência dos fatores de formas diferentes, conforme sintetizado na Tabela 5.1.

Tabela 5.1 - Síntese dos fatores e suas combinações que interferem em cada uma das características estudadas.

\begin{tabular}{|l||c|c|c|c|c|c|}
\hline \multirow{2}{*}{ Fatores e combinações } & \multicolumn{5}{|c|}{ Características } \\
\cline { 2 - 8 } & Rugosidade & $\begin{array}{c}\text { Alan. } \\
\text { A }\end{array}$ & $\begin{array}{c}\text { Plan. } \\
\text { S }\end{array}$ & $\begin{array}{c}\text { Conic. } \\
\text { Horiz. }\end{array}$ & $\begin{array}{c}\text { Conic. } \\
\text { Vert. }\end{array}$ & Perpendicularismo \\
\hline Velocidade & Não & Não & Sim & Não & Não & Sim \\
\hline Passes & Sim & Sim & Sim & Sim & Sim & Não \\
\hline Ferram. Diamantada & Sim & Sim & Não & Não & Não & Sim \\
\hline Sobremetal & Não & Não & Não & Não & Não & Não \\
\hline Velocidade * Passes & Não & Não & Não & Não & Não & Não \\
\hline $\begin{array}{l}\text { Velocidade * Ferram. } \\
\text { Diamantada }\end{array}$ & Não & Sim & Sim & Não & Sim & Sim \\
\hline Velocidade * Sobremetal & Não & Não & Não & Não & Não & Não \\
\hline Passes * Ferram. Diamantada & Não & Não & Não & Sim & Sim & Não \\
\hline Passes * Sobremetal & Sim & Sim & Sim & Sim & Sim & Não \\
\hline Ferram. Diamantada * & & & & & & \\
\hline Sobremetal & & & &
\end{tabular}

Existem outros fatores que não foram analisados neste trabalho e que podem também interferir nos resultados, como por exemplo a concentração do óleo refrigerante, a pressão de fixação entre outros. Esta análise pode ser melhor explorada em trabalhos posteriores. 


\title{
6- Referência Bibliográfica
}

\begin{abstract}
ABOUELATTA, O. B. e MÀDL, J. (2001), Surface roughness prediction based on cutting parameters and tool vibrations on turning operations, Journal of Materials Processing Technology, 118, $269-277$.
\end{abstract}

ALMEIDA, R. M. (2002), Estudo da retificação de ultra precisão de materiais frágeis, dissertação de Mestrado EESC - São Carlos S.P.

AXINTE, D. A. e NABIL, G. (2003), Tool condition monitoring in broaching, Wear 254, 370-382. School of Mechanical, Materials, Manufacturing Engineering and Management, University of Nottingham, University Park, Nottingham NG7 2RD, UK, Received 4 October 2002; accepted 17 December 2002.

AXINTE, D. A. (2005), Approach into the use of probabilistic neural networks for automated classification of tool malfunctions in broaching, International Journal of Machine Tools \& Manufacture.

BAPTISTA, A.L.B. (2002), Aspectos metalúrgicos na avaliação da usinabilidade de aços, Rev. Esc. Minas vol.55, no.2, Ouro Preto, Minas Gerais.

BOOTHROYD, G. e KHIGHT W. A. (1989), Fundamentals of machining and machine tools, 2a Edição, editora Dekker, New York, EUA, cap. 8. 
CAMARGO, R. (2005), Metodologia para avaliação da capabilidade de controle de superfícies técnicas usinadas em torno de ultra precisão, Tese Doutorado EESC/USP São Carlos S.P.

CHIAVERINI, V. (1984) Aços e ferro fundido, São Paulo: Associação brasileira de metais, $5^{\text {a. }}$ edição, p. 425-490.

CHIAVERINI, V. (1985) Tratamentos térmicos das ligas ferrosas, São Paulo: Associação brasileira dos metais.

COHEN, P. H., VOIGT, R. C. (2003), Machining Simulation of Ductile Iron and Its Constituents, Journal of Manufacturing Science and Engineering - May 2003.

DERFLINGER, V.; BRÄNDLE, H.e ZIMMERMANN H. (1999), New hard/lubricant coating for dry machining, Surface and Coatings Technology, 113, p. 286-292.

DINIZ, A.E.; MARCONDES, F.C.; COPPINI, N.L. (1999) Tecnologia da usinagem dos materiais São Paulo: MMEditora.

DOYLE, L. E. (1978), Processos de fabricação e materiais para engenheiros, Ed. Edgard Blucher LTDA, São Paulo - S.P.

FERRARESI, D. (1977) Fundamentos da usinagem dos metais, São Paulo: Editora Edgard Blucher. 
FREIRE, J. M. (1978), Tecnologia Mecânica - Máquinas limadoras e retificadoras, Livros Técnicos e Científicos Editora S.A., Rio de Janeiro-R.J., Volume 5, Cap.17.

GONÇALVES, M. T. T. (1995), Usinagem dos Metais, Apostila da Universidade Estadual Paulista - Bauru, S.P.

GUIMARÃES, V. A. (1999), Controle dimensional e geométrico - Uma introdução a metrologia industrial, Editora Universitária de Passo Fundo EDIUPF Passo Fundo- R.S.

IMASOGIE, B.I.; AFONJA, A. A. and ALI, J. A. (2000) Properties of ductile cast iron nodularised with multiple calcium-magnesium based master alloy, Materials Science and Technology, Fevereiro, vol. 16, p. 194-201.

KALPAKJIAN, S. e SCHIMID S. R. (2001), Manufacturing engineering and Technology, Ed. Prentice Hall, New Jersey, EUA, 4ª edição, pág. 616.

KRAR, S. F. e CHECK, A. F. (1997), Technology of machine tools, Editora McGraw Hill, $5^{\text {a }}$ edição, paginas 179-180.

LUCAS, E.M. (2003), Aspectos da Formação do Cavaco no Torneamento de Ferro Fundido Nodular Ferrítico, Tese de Mestrado EESC- USP São Carlos - S.P.

MAGALHÃES, R. C. A. (2006), Sistema para medição de erros de planicidade, Tese de Mestrado EESC - USP São Carlos - S.P. 
MO, S. P. et al (2005), An example of selection of cutting conditions in broaching of heatresistant alloys based on cutting forces, surface roughness and tool wear, Journal of Materials Processing Technology, 160, 382-389.

MORWANGA, R.O.; VOIGT, R.C. e COHEN, P.H. (2000) Influence of graphite morphology and matrix structure on chip formation during machining of continuously cast ductile irons, AFS Transaction, Pittsburg, p. 651-660.

NELSON, D. H. e SCHENEIDER, G. Jr. (2001), Applied Manufacturing Process Planning, primeira edição, Editora Prentice Hall, New Jersey-EUA.

PAHL, D. (1984), Técnicas do brochamento, apostila Abranálise, São Paulo.

RUFFINO, R. T. (1973), Processo de brochamento, publicação interna na Universidade de São Paulo, Escola de Engenharia de São Carlos, Departamento de Engenharia Mecânica.

SODHI, M. R. e TILIOUINE, K. (1996), Surface roughness monitoring using computer vision, Intenational Journal Machine Tools Manufacturing. Vol. 36, No. 7, pag. 817-828.

SUTHERLAND, J. W., SALISBURY, E. J. e HOGEI, F. W. (1997), A model for the cutting force system in the gear broaching process, International Journal of Machining Tools Manufacturing. Vol. 37, No. 10, pp. 1409-1421, 1997. 
TRENT, E. M. (1996) Metal Cutting, London, Editora: Butterworth Heinemann, $3^{\text {rd }}$ edition, p. 243. 